\title{
Report to Congress on the Potential Use of Lead in the Waste Packages for a Geologic Repository at Yucca Mountain, Nevada
}

\section{December 1989}





\section{DISCLAIMER}

This report was prepared as an account of work sponsored by an agency of the United States Government. Neither the United States Government nor any agency thereof, nor any of their employees, make any warranty, express or implied, or assumes any legal liability or responsibility for the accuracy, completeness, or usefulness of any information, apparatus, product, or process disclosed, or represents that its use would not infringe privately owned rights. Reference herein to any specific commercial product, process, or service by trade name, trademark, manufacturer, or otherwise does not necessarily constitute or imply its endorsement, recommendation, or favoring by the United States Government or any agency thereof. The views and apinions of authors expressed herein do not necessarily state or reflect those of the United States Government or any agency thereof. 


\section{DISCLAIMER}

\section{Portions of this document may be illegible in electronic image products. Images are produced from the best available original document.}


I. INTRODUCTION ...................... 1

II. THE ORGANIZATION OF THE REPORT . . . . . . . . . . . 1

III. THE ROLE OF THE WASTE PACKAGE AND

ITS DEFINITION IN REGULATIONS ............... 2

A. Functional and regulatory requirements ......... 2

B. Waste-emplacement environment ............. 3

C. The design of the waste package ............ 5

IV. POTENTIAL USES FOR LEAD IN THE WASTE PACKAGE . . . . . . . 12

V. THE PROPERTIES OF LEAD AS A COMPONENT OF THE WASTE PACKAGE . - 16

A. Corrosion resistance .............. 16

B. Shielding from penetrating radiation ......... 17

C. Heat-transfer properties .............. 19

D. Mechanical properties .............. 19

E. Casting technology ................ 20

F. Environmental releases and regulatory considerations . . 21

G. Sumnary of properties ............... 23

प1. Costs of using leä fillers or liners . . . . . . . . 23

VI. APPLICATION OF LEAD IN THE U.S. REPOSITORY PROGRAM . • • • 25

A. Application in the conceptual design waste-package strategy 25

B. Application of lead in waste-package alternatives . . . . 26

VII. SUMMARY AND CONCLUSIONS. . . . . . . . . . . . . . 26

REFERENCES . . . . . . . . . . . . . . . . . . . 28

Appendix A PREVIOUS RESEARCH ON LEAD AS A POTENTIAL

WASTE-PACKAGE MATERIAL IN NATIONAL PROGRAMS. . . . 30

United States............. . 30

Sweden...................... 33

Canada .................. 33

Belgium ................ . . . 35

Argentina ................. 36

Germany ................... 37

Switzerland ................. 38

Great Britain ................ 39 
TABLE OF CONTENTS (cont.)

$\underline{\text { Page }}$

Appendix B LEAD AS A CORROSION BARRIER . . . . . . . . . . 46

Appendix C LEAD AS A RADIATION BARRIER . . . . . . . . . . 57

Appendix D LEAD AS STRUCTURAL MATERIAL . . . . . . . . . . 61

Appendix E LEAD CASTING IN WASTE CONTAINERS . . . . . . . . . 67

Appendix F COSTS OF USING LEAD IN WASTE PACKAGES . . . . . . . 75

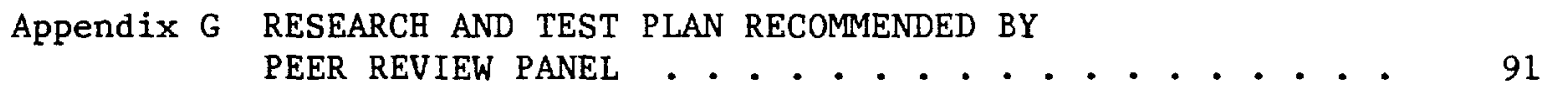




\section{REPORT TO CONGRESS ON THE POTENTIAL USE OF LEAD \\ IN THE WASTE PACKAGES FOR A GEOLOGIC REPOSITORY \\ AT YUCCA MOUNTAIN, NEVADA}

\section{INTRODUCTION}

In the Report of the Senate Committee on Appropriations accompanying the Energy and Water Appropriation Act for 1989, the Committee directed the Department of Energy (DOE) to evaluate the use of lead in the waste packages to be used in geologic repositories for spent nuclear fuel and high-level waste. The evaluation that was performed in response to this directive is presented in this report. This evaluation was based largely on a review of the technical literature on the behavior of lead, reports of work conducted in other countries, and work performed for the waste-management program being conducted by the DOE. Furthermore, the initial evaluation was limited to the potential use of lead in the waste packages to be used in the repository. The DOE may also consider the use of lead in other waste-management activities-namely, monitored retrievable storage and transportation--but these applications of lead are not included in this report. Also, the focus of this report is post closure performance and not on retrievability and handling aspects of the waste package.

The scope of the evaluations of lead as discussed in this report were focused on the applicability of $1 \in a d$ in the conceptual reference design of the waste package that DOE is planning to use at the Yucca Mountain site in Nevada if this site is found to be acceptable. Currently, this site is being sharacterized as the candidate site for the first U.S. geologic repositor $y$. The preliminary conceptual design is described in the Site Characterization Plan for Yucca Mountain (DOE, 1988a) and is based on assumptions that were derived from current knowledge of the site conditions, and those assumptions must be confirmed by the site characterization process. The evaluations of the applicability of lead as a construction material in the waste package as discussed in this report focuses on its potential use in the conceptual reference design. Such a use of lead in the current DOE conceptual reference design would not enhance compliance with the functional and regulatory requirements for the waste package, the information deemed necessary to demonstrate compliance with the regulatory requirements of the U.S. Nuclear Regulatory Commission (NRC), and the underground waste-emplacement environment expected at the Yucca Mountain Site. If the expected conditions do not exist, then there would be a need to consider alternative waste packages. However this Report does not evaluate the potential for lead to meet various functional and regulatory requirements for any future alternative waste packages. An additional research effort would be required to assess the appliability of lead in such alternative waste packages. Research tasks to evaluate the use of lead in an alternative waste package program are discussed in Appendix $G$ of this Report.

\section{THE ORGANIZATION OF THE REPORT}

The report consists of seven sections and seven appendixes. It starts with background information on the role and the definition of the waste package, the functional and regulatory requirements for the waste package, the waste-emplacement environment, and the design of the waste package. Then it discusses the potential uses of lead in the waste package and reviews the 
properties of lead as a potential waste-package component. These evaluations are followed by a discussion of environmental regulations applicable to the use of lead, preliminary estimates of costs, and summary and conclusions. The appendixes present more detailed information on previous research related to the use of lead in waste packages (Appendix A), the performance of lead as a corrosion barrier (Appendix B), the performance of lead as radiation shield (Appendix C), the properties of lead as a structural material (Appendix D), and the casting of lead into disposal containers (Appendix E), estimates of the costs of using lead in the waste package (Appendix F), and a research and test plan recommended by a peer review panel (Appendix G).

\section{THE ROLE OF THE WASTE PACKAGE AND ITS DEFINITION IN REGULATIONS}

In order to isolate radioactive wastes for thousands of years into the future, a geologic repository will rely on both natural and engineered barriers. The natural barriers are the physical, mechanical, chemical, and hydrologic characteristics of the geologic environment that, individually and collectively, act to minimize or preclude the transport of radioactive materials (radionuclides) to the accessible environment. The engineered barriers are the manmade components designed to prevent the release of radioactive material from the underground repository into the natural barriers. For the Yucca Mountain site in Nevada--the site selected by the Congress (in the Nuclear Waste Policy Amendments Act of 1987) for characterization as the candidate site for the first repository--the primary engineered barrier is the waste package.

The waste package is defined in the Federal regulations promuigated for geologic repositories in 10 CFR Part 60 (NRC, 1988) and 10 CFR Part 960 (DOE, 1984) as "the waste form and any containers, shielding, packing, and other absorbent materials immediately surrounding an individual waste container." The design of the waste package depends mainly on the characteristics of the waste form and the host rock of the repository, and the environmental conditions expected in the vicinity of the waste package. Because of the functional and regulatory requirements that the waste package must meet, its design and the demonstration of its performance pose a significant technical challenge in the development of the repository. In addition, the waste package represents a significant portion of the cost of a repository. For the Yucca Mountain site, a repository filled to the current statutory limit equivalent to 70,000 metric tons of heavy metal (uranium) would contain approximately 40,000 waste packages, and for the current design the cost of these packages is estimated at about $\$ 1.5$ billion. This estimate is not to be interpreted as being precise or final in any sense because the final design has not been selected and the program is still evolving. For example, up to 73,000 packages could be emplaced if a nonconsolidated spent fuel design is selected.

\section{A. Functional and regulatory requirements}

The waste package must be designed to meet various functional and regulatory requirements, including those specified by the Nuclear Regulatory Commission in 10 CFR Part 60 (NRC, 1988). The following general design criteria for the waste package are prescribed in 10 CFR 60.135: 
1. "Packages...shall be designed so that the in situ chemical, physical, and nuclear properties of the waste package and its interactions with the emplacement environment do not compromise the function of the waste packages or the performance of the underground facility or the geologic setting."

2. "The design shall include but not be limited to consideration of the following factors: solubility, oxidation/reduction reactions, corrosion, hydriding, gas generation, thermal effects, mechanical strength, mechanical stress, radiolysis, radiation damage, radionuclide retardation, leaching, fire and explosion hazards, thermal loads, and synergistic interactions."

This section of 10 CFR Part 60 goes on to prescribe specific criteria for waste-package design (i.e., it prohibits explosive, pyrophoric, and chemically reactive materials; it prohibits free liquids in amounts that could compromise the achievement of performance objectives; and it specifies requirements for handling and unique identification) and the waste form (e.g., solidification, the consolidation of particulate waste, and absence of combustible materials).

Also addressed by the design of the waste package are the DOE's requirements in $10 \mathrm{CFR} 960.5$ (DOE, 1984). These requirements infer that the production and the emplacement of the waste package are to be feasible with reasonably available technology and that the design of the waste package cannot make the application of reasonably available technology impractical for other portions of the repository system or operations.

However, the most challenging requirements for the engineered-barrier system are ihose for performance after tile permanent closure of the repository from 10 CFR 60.113. The engineered-barrier system is defined in $10 \mathrm{CFR}$ Part 60 as "the waste package and the underground facility." In 10 CFR 60.113, the NRC requires that, assuming anticipated processes and events, the engineered-barrier system is to be designed so that (1) the containment of waste within the waste package will be substantially complete for 300 to 1000 years after the closure of the repository and (2) the release of any radionuclide from the engineered-barrier system after the containment period will not exceed one part in 100,000 of the 1000-year inventory of that radionuclide.

\section{B. Waste-emplacement environment}

At the Yucca Mountain site in Nevada, the repository would be constructed about 1000 feet below the surface; it would be constructed in the unsaturated zone in a volcanic rock called "tuff" (the Topopah Spring unit of the Paintbrush Tuff Formation). The unsaturated zone is the rock mass (and the fluids contained in this rock mass) between the surface of the land and the water table. In the unsaturated zone, most of the pores in the rock matrix are not completely filled with water (i.e., the rocks are unsaturated) and the matrix pores will exert a suction action on water flowing through the tuff. The proposed horizon for the repository is a moderately to densely welded tuff of relatively high fracture density. Current estimates are that only a small part of the rain that falls on Yucca Mountain (probably less than 0.02 inch of the approximately 6 inches that falls annually (DOE, 1988b)) percolates to the deeper units of the unsaturated zone, and only a small vertical ground-water 
flux is expected in the Topopah Spring tuff. Also, under certain conditions, for example, intermittent fracture flow, some waste packages may have contact with 1imited amounts of water (DOE, 1988a). The conceptual design approach includes two scenarios, the first of which anticipates that no liquid water will contact any of the packages, and the second (a bounding case) allows $1 \%$ of the boreholes to be initially contacted by liquid water and limited amounts of water to contact $5 \%$ of the packages for times $<300$ years and $10 \%$ of the packages for 300 to 1000 years after repository closure (DOE, 1988a).

The unsaturated tuff is expected to provide a waste-emplacement environment that would be favorable for the long-term performance of the waste package. For example, the water in the unsaturated zone is expected to have a nearly neutral $\mathrm{pH}$ value and low levels of corrosives, such as chloride ions. A water composition assumed to be typical of the unsaturated zone at Yucca Mountain is given in Table 1. (The composition given in Table 1 is for water taken from a well (we11 J-13) located east of Yucca Mountain and used in sitecharacterization studies; the water from this well is assumed to be very similar to the water contained in the unsaturated zone at the site.)

Table 1. The composition of water from a well east of Yucca Mountain ${ }^{a}$

\begin{tabular}{lc}
\hline Constituent & $\begin{array}{c}\text { Concentration } \\
\text { (millimoles per 1iter) }\end{array}$ \\
\hline Sodium & 1.96 \\
Potassium & 0.14 \\
Calcium & 0.29 \\
Magnesium & 0.07 \\
Measured alkalinity $\quad$ (as bicarbonate) & 2.34 \\
Sulfate & 0.19 \\
Chloride & 0.18 \\
Silica & 1.07 \\
\hline pH & 6.9 units \\
\hline
\end{tabular}

${ }^{a}$ Data from Ogard and Kerrisk (1984).

Another favorable feature of the site is the low pressure exerted on the disposal containers, which is expected to be approximately 1 atmosphere. There would be no hydrostatic pressure because the repository would be located above the water table, and the waste packages would not be expected to be subjected to lithostatic pressure because the host rock is not expected to creep after waste emplacement, although there is some possibility of rock-fall induced loading ( $<1000 \mathrm{~kg} /$ package) due to borehole failures. 
The SCP assumes that a certain fraction of the boreholes will be in contact with water; however, as already mentioned, the water available for the corrosion of the disposal containers and the dissolution of the waste form is expected to be limited to very small amounts. The operation of the repository ventilation system during the preclosure period and the heat emitted by the waste after emplacement in the repository would tend to dry out the host rock in the vicinity of the waste packages and thus aid in preventing liquid water from coming into contact with most of the disposal containers for the first several hundred years. (However, in assessing the performance of the waste package, the DOE does not at present plan to rely on these phenomena.) Hence, only limited corrosion by liquid water is expected. Oxidation by an oxidizing steam environment at a pressure of about 1 atmosphere is also possible during this period.

\section{The design of the waste package}

The status of the design

In the current conceptual design developed for the site characterization plan (the SCP conceptual design)--the waste package for the Yucca Mountain site consists of the waste form and the disposal container. There is also a pour canister to contain the glass waste form. It should be noted, however, that the design will continue to evolve as data from site characterization are obtained and the more detailed phases of design are completed--the advanced conceptual design, which will include evaluations of alternative configurations for the waste package, and the license-application design.

In addition to the conceptual design, DOE also has plans for developing alternative designs which will be described in detail below. Basically, this program is aimed at developing waste package designs that will have superior capabilities for meeting the regulatory requirements under environmental conditions that are more severe than those currently expected at the Yucca Mountain site. A variety of design concepts including the use of additional components (e.g. filler, liner, etc.) and alternative materials (including lead) will be considered in this program.

A brief description of the waste package and its design is given in the paragraphs that follow. A more complete discussion can be found in the site characterization plan for the Yucca Mountain site (DOE, 1988a, Chapter 7 and Sections 8.3.5.9 and 8.3.5.10).

\section{The waste form}

The waste form is either spent fuel from commercial light-water reactors (both pressurized-water reactors and boiling-water reactors) or high-level waste from defense or commercial sources. In the SCP conceptual design (DOE, 1988a), it was assumed that most of the spent fuel would be consolidated* either at the repository or before shipment to the repository; the remainder would be disposed of as intact assemblies whenever consolidation is impràctical. 
It was assumed for design purposes that, in the case of spent fuel from pressurized-water reactors (PWRs), which account for about two-thirds of all reactors in the United States, one spent-fuel assembly will have a thermal decay power of about 0.55 kilowatt; for spent-fuel assemblies from boiling-water reactors, a thermal decay power of 0.18 kilowatt was assumed. These assumptions are based on 10-year-old spent fuel with a nominal burnup (i.e, the amount of energy derived from each assembly before it is discharged from the reactor). In the SCP conceptual design, it was assumed that six such assemblies are loaded into a disposal container, and the gamma-radiation dose rate at the outer surface of the container would be approximately 50,000 rads per hour. The neutron flux at the container surface would be about 10,000 neutrons per square centimeter per second.

The high-level waste, from both defense and commercial sources, would be in the form of a solid matrix, such as borosilicate glass, solidified in stainless-steel canisters. The conceptual design high-level-waste package would have a thermal-power level in the range of 200 to 1500 watts, depending on the source and the age of the wastes in the matrix. The gamma-radiation dose at the outer surface of the high-level-waste disposal container would be about 5500 rads per hour, and the neutron dose rate is expected to be very low.

\section{The disposal container}

In the SCP conceptual design, the disposal container for both waste forms is a sealed thin-walled metal cylinder with an outside diameter of 26 inches. A thin-walled container can be used because, as described above, the pressure in the repository is expected to be $1 \mathrm{c}$, and the container would not be subjec rea to significant hydrostatic or lithostatic pressure. The walls of the container would be about three-eighths of an inch thick; the thickness was chosen to provide the strength necessary for handling. The length would vary from 10.5 feet for high-level waste (see Figure 1) to about 15.5 feet for spent fue1 (Figure 2).

The disposal container would be constructed of corrosion-resistant material. Candidate container materials are discussed below.

In the SCP conceptual design, it was assumed that, after being loaded with the waste, the disposal container would be filled with an inert gas to protect the waste form from being oxidized, and the top of the container would be welded closed. The top would have a fixture for lifting and lowering the container. A loaded disposal container would weigh from 6000 to 14,000 pounds, depending on the quantity and the type of waste.

*It should be noted that no decision on the consolidation of spent fuel has yet been made. The DOE plans to conduct systems studies to determine whether consolidation would be beneficial for waste management and disposal. 


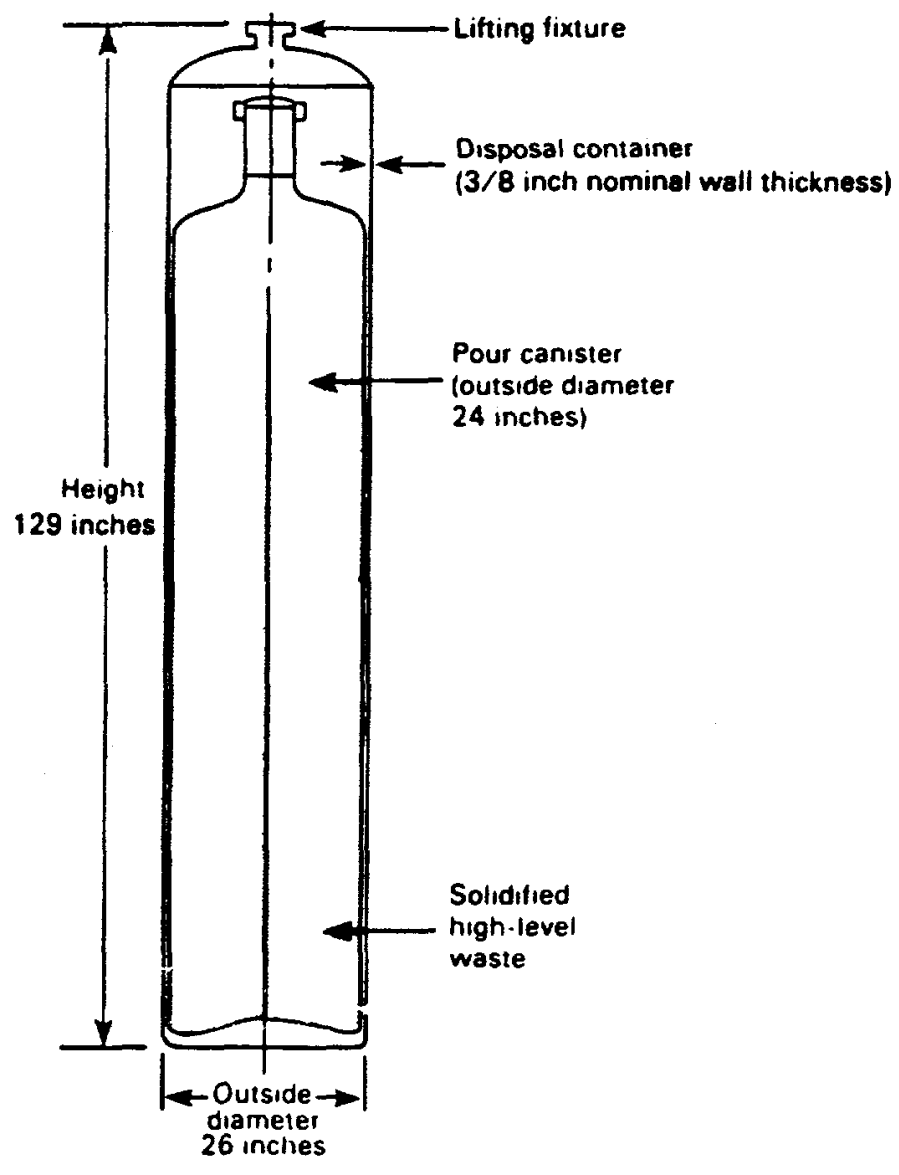

Figure 1. Disposal container for defense and commercial high-level waste.

The containers for spent fuel would contain steel compartments designed to keep the spent fuel in a stable position and to help in loading the containers. To accommodate different types of spent fuel and to accommodate both consolidated and unconsolidated fuel, several arrangements for these compartments have been designed, and some of these arrangements are shown in Figure 2.

Six metallic alloys are currently being evaluated as candidate materials for the container application (304L stainless steel, 316L stainless steel, a high-nickel alloy (Alloy 825), copper (oxygen free), a 70/30 copper-nickel 


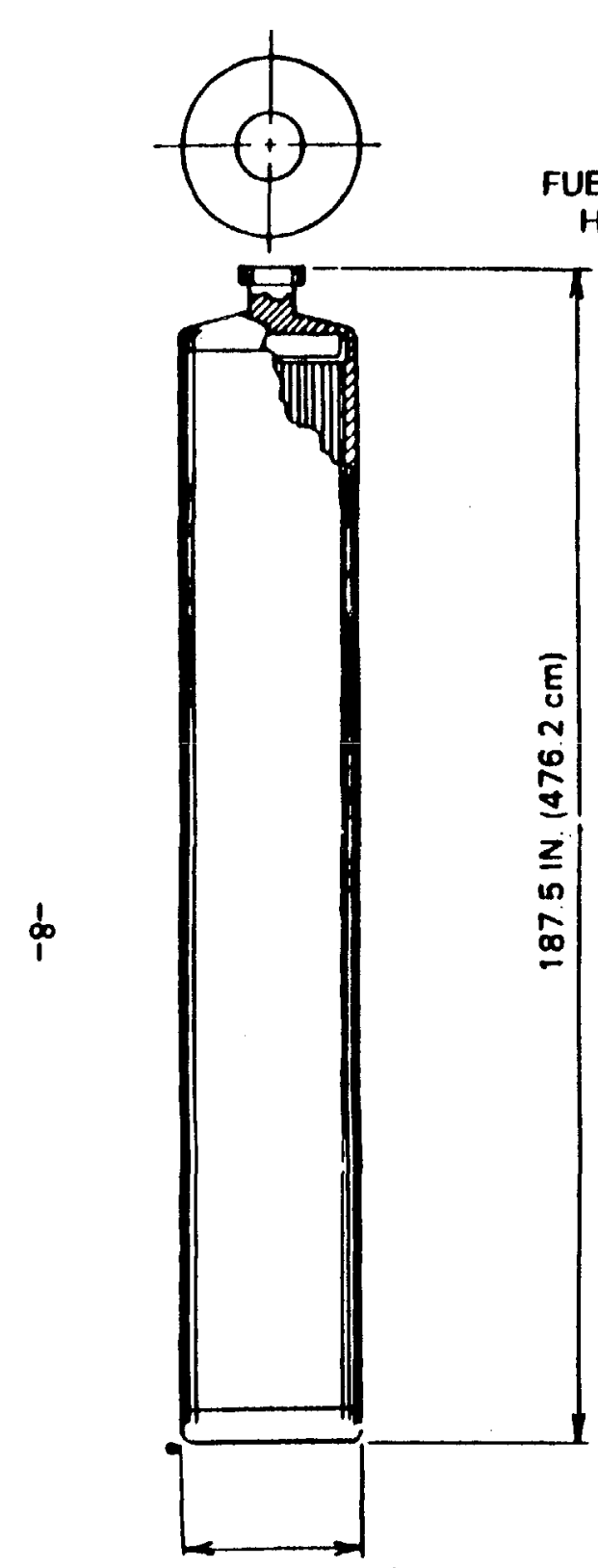

26 in. $(66 \mathrm{~cm})$
RODS FAOM 1 PWP

FUEL ASSEMBLY

UEL ASSEMBLY HARDWARE -

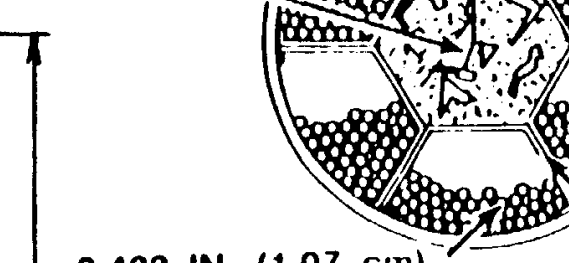

0.422 IN. $(1.07 \mathrm{~cm})$ DIAMETEA ROOS

CONFIGUAATION 1.

SIX CONSOLIDATED PWA ASSEMBLIES

6 BWR FUEL ASSEMBLIES

$5.5 \times 5.5 \mathrm{IN} .(14 \times 14 \mathrm{~cm})$

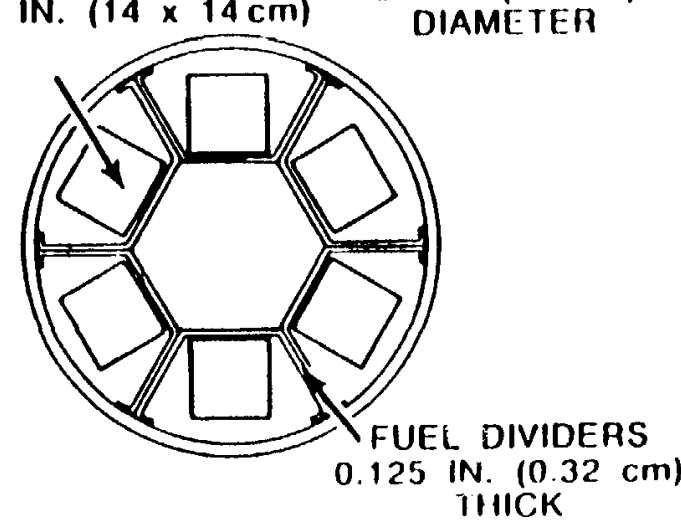

CONFIGURATION 3.

SIX INTACT BWR ASSEMBLIES

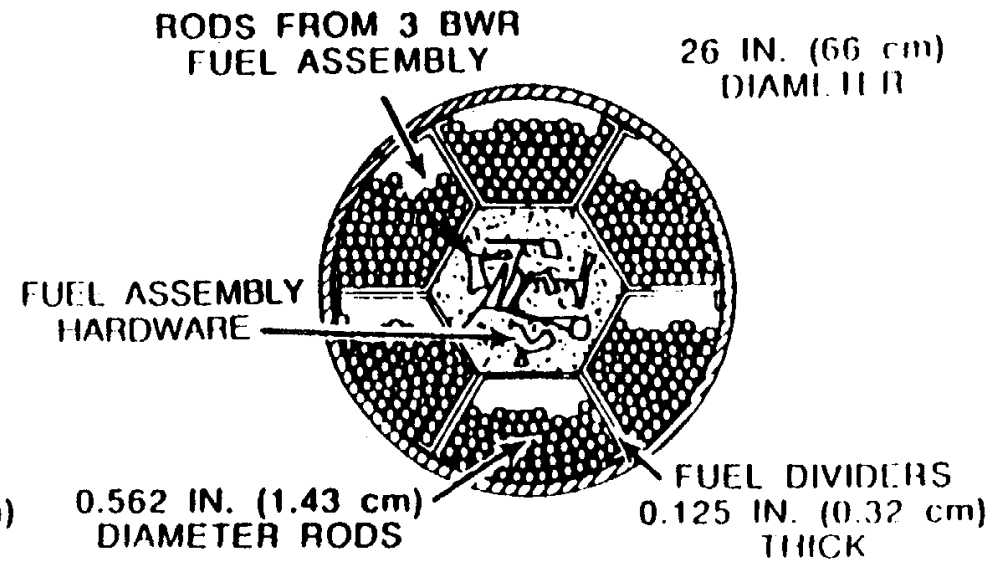

CONFIGUAATION 2.

EIGHTEEN CONSOLIDATED BWR ASSEMBLIES

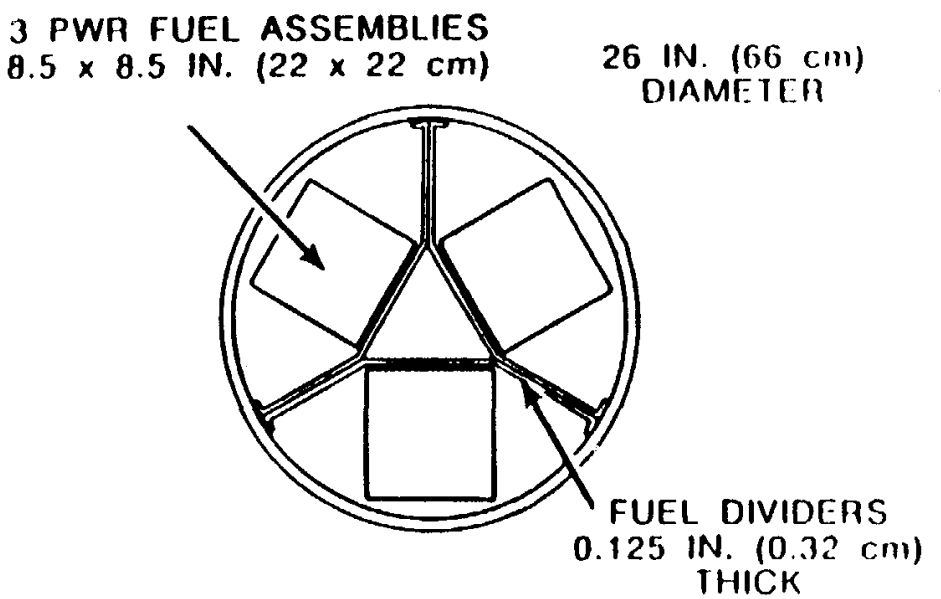

CONFIGURATION 4.

THREE INTACT PWR ASSEMBLIES

PWR - PRESSURIZED WATER AI:ACIION BWR. BOILING WATER REACTOI

Figure 2. Yucca mountain project reference spent fuel container. 
alloy, and aluminum bronze). One of these alloys is expected to be selected as the conceptual design container material by a process described in detail in the Site Characterization Plan for the Yucca Mountain site (DOE, 1988a).

\section{Conceptual design waste-package strategy}

To show compliance with the performance objectives specified in 10 CFR 60.113 for the engineered-barrier system (i.e., substantially complete containment within the waste packages for 300 to 1000 years and subsequent control of radionuclide releases at low annual rates), the DOE has developed a conceptual design waste-package strategy for the Yucca Mountain site. This strategy, described in detail in Sections 8.3.5.9 and 8.3.5.10 of the Site Characterization Plan (DOE, 1988a), relies on the favorable natural characteristics of the repository environment, as described above. In addition, the disposal container and the waste form are relied on to perform acceptably so that performance goals are achieved. The DOE's goal is to design containers that provide complete containment for 1000 years (allowing for recognized technical uncertainties). After the container is breached, the waste form, acting in conjunction with the environmental conditions and the presence of the breached container, is expected to 1 imit radionuclide releases to low rates for very long times. This resistance to the release of radionuclides is attributed primarily to the mass-transfer resistance of the spent-fuel cladding and the containers (even in their breached condition). In addition, further inhibition of releases will be due to the chemical characteristics of the waste itself--i.e., the dissolution rate and the solubility limits.

At present, the DOE believer that the conceptual design of the waste paichase will be capable of meeting all regulatory requirements, and that tuis capability is expected to be demonstrated during site characterization. Therefore, if the site characterization program and further materials testing confirms currently available information about the expected waste-emplacement environment, there appears to be no need for augmenting this conceptual design. Alternate designs are being considered in accordance with Federal regulations (see below) and in the event that the site characterization reveals a more severe environment than is now anticipated.

Program for the evaluation of alternative designs

In 10 CFR 60.113(a), the Nuclear Regulatory Commission requires that the demonstration of waste-package performance after repository closure--that is, substantially complete containment of the wastes within the waste packages and the subsequent gradual release of radionuclides from the engineered-barrier system--be based on "anticipated processes and events." These processes and events are defined as those that are "reasonably likely to occur during the period the intended performance objective must be achieved." The DOE's strategy for demonstrating post-closure compliance for the waste package and the conceptual waste-package design are based on a set of anticipated processes and events (DOE, 1988a, Section 8.3.5.9-1) that are 
representative of the current (circa 1988) understanding of the Yucca Mountain site. The DOE expects that the adequacy of the strategy and the conceptual design will be confirmed through site characterization and the performance confirmation program.

However, in 10 CFR $60.113(\mathrm{c})$, the Nuclear Regulatory Commission advises that "additional requirements may be found necessary to satisfy the overall performance objective as it relates to unanticipated processes and events"; the latter are defined as the processes and events that are "sufficiently credible to warrant consideration." Furthermore, 10 CFR 60.21, which specifies the content of the license application for the repository, requires, among other things, a safety analysis report that includes "a comparative evaluation of alternatives to the major design features that are important to waste isolation, with particular attention to alternatives that would provide longer radionuclide containment and isolation" (10 CFR 60.21(c)(1)(ii)(D)).

With respect to $10 \mathrm{CFR} 60.113$, the DOE plans to design the waste packages to meet the requirements for containment and gradual release for anticipated processes and events, although the license application will also contain analyses of the performance expected under unanticipated processes and events. The strategy for the demonstration of compliance is described in detail in the Site Characterization Plan (DOE, 1988a); this strategy was based on the current expectations of the results of site characterization--that is, that the rock unit in which the repository would be constructed is in the unsaturated zone and that the waste-emplacement environment is such that the containers will be subjected to high humidity, with possible intermittent periods of contact with mildly oxidizing liquid water and with no external mechanical loading on the waste package in site.

It is possible that the results of site characterization may indicate that greater quantities of water, more corrosive ground water, or higher external loadings are sufficiently likely at the site to warrant the inclusion of one or more of these potential conditions in the set of anticipated processes and events. For this reason, it may be necessary to provide waste packages with capabilities superior to those currently envisioned as capable of meeting the regulatory requirements.

Furthermore, the results of site characterization may not be sufficiently conclusive with regard to some low-probability occurrences that, though clearly unanticipated, might have sufficiently serious consequences to require the consideration of mitigating measures in the waste-package design in order to meet the "reasonable assurance" standard required by the Nuclear Regulatory Commission (10 CFR 60.113( $a$ and $c$ )).

It is to meet these needs that the DOE is planning a program for evaluating alternative waste-package concepts and materials, as described in the Site Characterization Plan (DOE, 1988a, Section 8.3.5.9). In this program the DOE plans to evaluate a wide variety of waste-package design concepts, including the use of additional components and alternative materials (both metals and nonmetals), with enphasis on improving the capability (in comparison with the conceptual design) to withstand larger quantities of 
ground water, ground water that is more corrosive, and higher external loadings. If the site is found to be suitable, the results of these investigations will be included in the Safety Analysis Report submitted as part of the license application for the repository, in order to satisfy the 10 CFR 60.21 requirements discussed above and to provide the Nuclear Regulatory Commission with the design information and performance analyses needed to comply with 10 CFR $60.113(\mathrm{c})$.

Table 2 lists some potential alternative concepts and materials that have been tentatively identified for evaluation in the Site Characterization Plan (DOE, 1988a). Lead is specifically identified as a material to be considered for use as a filler. However, Table 2 is not comprehensive, and as the evaluation of alternatives is planned and conducted, lead and lead alloys will be considered as candidate materials for appropriate applications and will be objectively evaluated against other candidate materials. As the design-and-evaluation effort proceeds, appropriate testing programs will be developed to ensure that the selected concepts provide, with a reasonable degree of certainty, viable alternatives at the time of license application.

Table 2. Potential alternative concepts and materials for the waste package

Rationale

Ceramic liner inside metallic container; alumina and titania are primary candidates

Double-walled (bimetallic) container; nickel- or iron-based alloys over copper alloy

Corrosion-resistant alloy container; titanium alloys, high-nickel alloys

Coatings applied to container wall; ceramic and metallic

Fillers in void spaces inside the container: magnetite, glass, aluminum, copper, lead, zinc
Chemical stability of ceramics

Outer barrier for high temperature, high gamma-radiation resistance; inner layer for lower temperature, low gammaradiation resistance

Alloys that possess greatly enhanced resistance to corrosion, particularly stress corrosion and other localized corrosion phenomena

Corrosion resistance

Corrosion resistance, mechanical support for container, and resistance to radionuclide release 
As explained in more detail in Appendix A, lead has been or is being analyzed as a waste-package component in the waste-management programs of Sweden, Canada, Argentina, the Federal Republic of Germany, Switzerland, the United Kingdom, and the United States. In addition, the Commission of the European Communities (CEC) is sponsoring a program in Belgium that is investigating the use of lead. Because lead and its alloys do not, in general, have the mechanical strength and other mechanical properties required of a "stand alone" material of construction, particularly for elevated-temperature use, lead is not currently being considered as the sole material for the disposal container itself (see Appendixes $A$ and $D$ ). The metal is soft, malleable, and easily abraded, and it creeps at relatively low stress levels even at room temperature. However, lead

has a rather low compressibility under uniform external loading, and this property can be exploited in waste-package designs by using lead as a filler material within thin-walled containers. In these designs, lead could prevent excessive deformation caused by external loading of the thin shell.

In all of the national programs mentioned above, lead was considered as some type of inside filler or liner, and in some of the programs it was considered only for high-level waste or the by-products of spent-fuel reprocessing. The German program, for example, considered using lead as a matrix in which pellets of vitrified high-level waste would be embedded, whereas the CEC-sponsored Belgian program examined the use of lead for the disposal of cladding hulls.

At present, the use uf lead remains an option in the Argentinian, the Beigian, Canadian, and Swedish programs. Lead is an option as a stabilizing (filler) material in the Swedish program, as a secondary corrosion barrier and structural-support material for thin-walled containers in Canada, and as a liner and a filler in Argentina. In the CEC-sponsored Belgian program, it is an option as a corrosion-resistant liner in waste packages containing canisters of cladding hulls.

A summary of the waste-emplacement environment expected at the Yucca Mountain site and at the sites proposed for repositories in other countries is given in Table 3. As this table shows, much higher temperatures and generally different environmental conditions are expected to prevail at a repository at the Yucca Mountain site, and none of the foreign designs is directly applicable. Table 3 shows that, in comparison with the available information on the site characteristics in the foreign programs, the characteristics of the Yucca Mountain site are unique in many respects. This uniqueness limits the applicability of research and experience from other countries to the U.S. program. However, to the extent that it is relevant, the foreign experience is factored into the evaluations of the use of lead in the U.S. waste-package program. 
Table 3. Expected waste-emplacement environments at proposed repository sites in the United States and other countries

\begin{tabular}{|c|c|c|c|c|c|c|}
\hline Country & Host rock & $\begin{array}{l}\text { Maximum } \\
\text { container } \\
\text { temperature } \\
\left({ }^{\circ} \mathrm{C}\right)\end{array}$ & $\begin{array}{l}\text { Maximum } \\
\text { pressure } \\
\text { (MPa) }\end{array}$ & $\begin{array}{l}\text { Chemical characteristics } \\
\text { of the ground water }\end{array}$ & $\begin{array}{l}\text { Packing } \\
\text { (backfill) }\end{array}$ & Reference \\
\hline United States & Tuff & 250 & $0.1^{\star}$ & Neutral ground water & None & DOE (1988a) \\
\hline Argent ina & Granite & 80 & 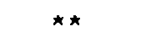 & $\star *$ & & De Miche1i (1986) \\
\hline Belgium & Clay & 100 & 4 & $\begin{array}{l}\text { Potentiall: corrosive } \\
\text { but containment not } \\
\text { critical }\end{array}$ & Sand & $\begin{array}{l}\text { Bonne and Manfroy } \\
(1986) \text {, Arup (1985) }\end{array}$ \\
\hline Canada & $\begin{array}{l}\text { Granite or } \\
\text { Gabbro }\end{array}$ & 100 & $>9.8$ & High-salinity water & $\begin{array}{l}\text { Sand and } \\
\text { Bentonite }\end{array}$ & Couture (1985) \\
\hline Germany & Salt dome & 150 & 30 & Salt brine & Salt & Merz et al. (1986) \\
\hline Sweden & $\begin{array}{l}\text { Granite or } \\
\text { Gnetss }\end{array}$ & 80 & $>15$ & Neutral ground water & Bentonite & SKBF/KBS (1983) \\
\hline Switzerland & $\begin{array}{l}\text { Crystalline } \\
\text { rock }\end{array}$ & 155 & $>30$ & $\begin{array}{l}\text { Saline, reducing } \\
\text { ground water }\end{array}$ & Bentonite & $\begin{array}{l}\text { Knecht and } \\
\text { McCombie (1986) }\end{array}$ \\
\hline $\begin{array}{l}\text { United } \\
\text { Kingdom }\end{array}$ & $\begin{array}{l}\text { Granite, } \\
\text { others }\end{array}$ & 150 & ** & $\star *$ & $\begin{array}{l}\text { Possibly } \\
\text { Bentonite } \\
\text { or cement }\end{array}$ & Marsh (1983) \\
\hline
\end{tabular}

* 0.1 megapascal (MPa) is equal to 1 atmosphere.

** no information. 
Possible applications of lead in the U.S. waste-package program are follows:

1. Hs shown in Figure 3, on the exterior of the metal barrier in the reference design (e.g., as a corrosion barrier or as a radiation shield). This application is not considered to be viable for lead.

2. As shown in Figure 4, in the interior, as a "filler" (to assist. in preserving the integrity of the cladding as a radioisotope and corrosion barrier, to provide an additional corrosion barrier, to provide structural support to the container, to provide shielding, to enhance heat transfer within the container, and to prevent the accumulation of water for criticality control by filling of voids.)

3. As shown in Figure 5, in the interior, as a "liner" (to provide a secondary corrosion barrier or to provide radiation shielding).

4. As the primary metal barrier (i.e., as a direct substitute for the metal-barrier materials in the reference design). This application is not considered to be viable for lead.

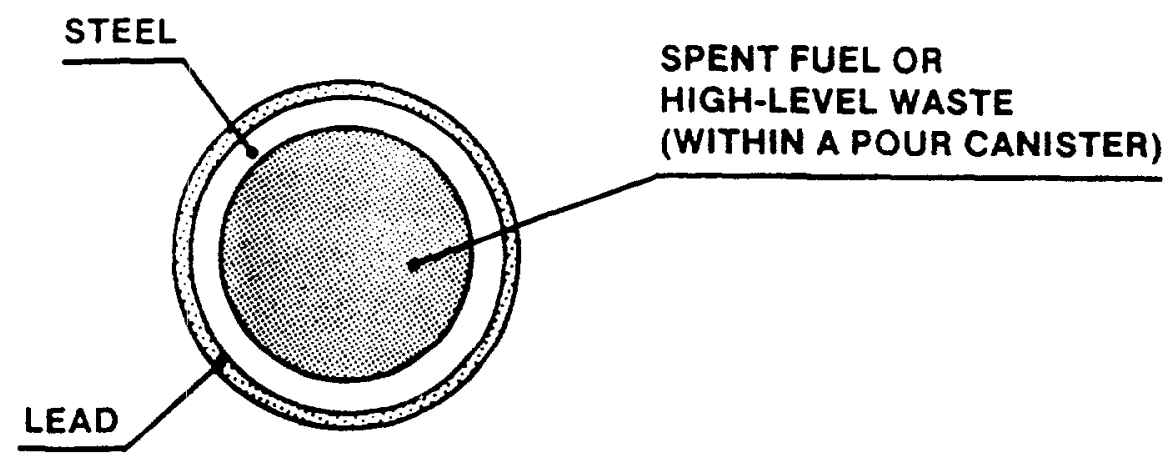

Figure 3. Waste package cross section with lead on exterior of container. 
The section that follows summarizes the properties and characteristics of lead relevant to its potential use in each of the above applications. This summary is based on the current state of knowledge about lead as discussed in greater detail in the appendixes to this report. It is followed by an assessment of the potential for the use of lead in the U.S. waste-package program.

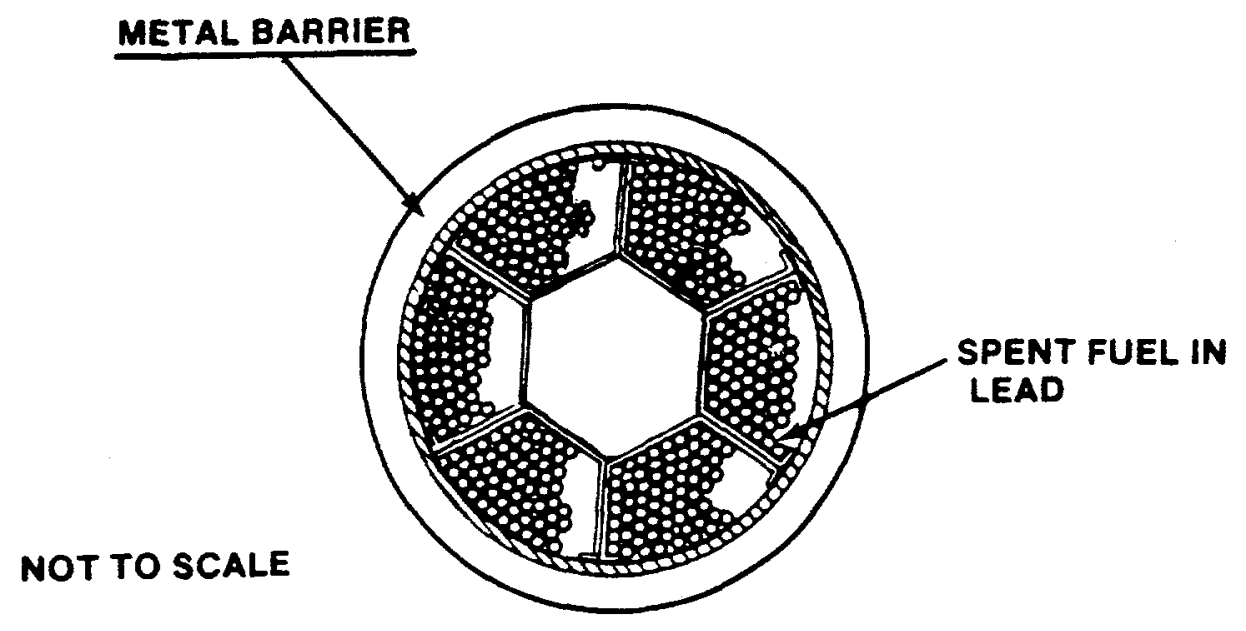

Figure 4. Waste package cross section with internal lead filler.

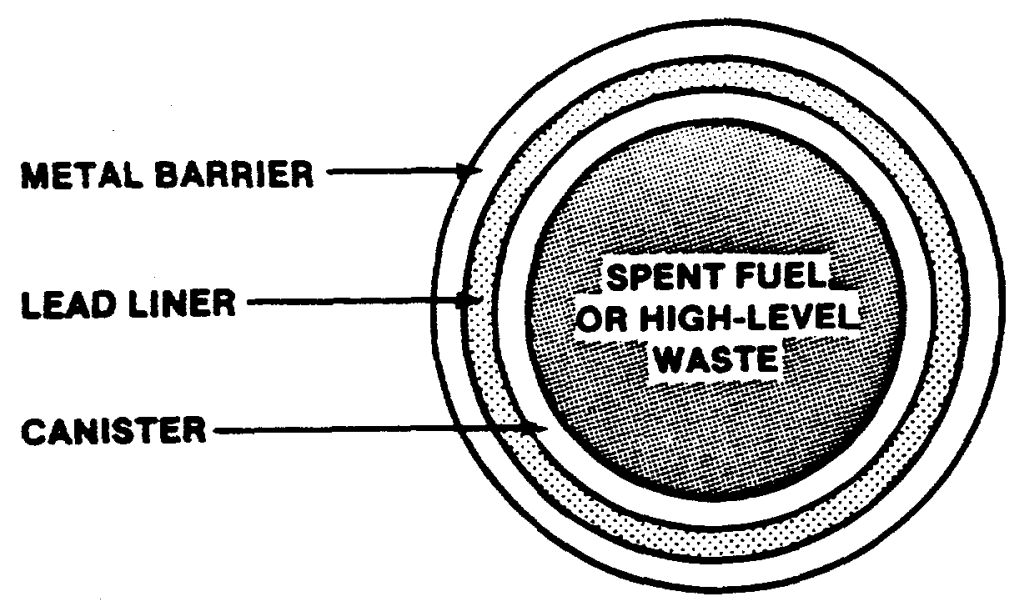

NOT TO SCALE

Figure 5. Waste package cross section for lead liner design. 
In the discussion of lead properties that follows, it should be remembered that the functional requirements described previously (Section III A) are applicable to all waste package components, but, whereas the degree of reliance on each component has been defined for the conceptual design, this has not been done as yet for possible alternative designs. Thus for the conceptual design, reliance is primarily placed on the metal barrier (the container) for containment over the first 1000 years after repository closure, and the waste form (also, to some extent, the container) contributes limiting radionuclide release rates. For an alternative design, which may involve filler or liner components, the degree of reliance on each of these components (versus reliance on the container and waste form) to fulfill the functional requirements has not yet been defined.

\section{v. THE PROPERTIES OF LEAD AS A COMPONENT OF THE WASTE PACKAGE}

\section{A. Corrosion resistance}

Conflicting experimental data have been reported for the general corrosion rates of lead in the type of environment (hot humid air and aerated steam) that is expected to occur at the Yucca Mountain site after the closure of the repository (see Appendix $B$ for a more detailed discussion of lead as a corrosion barrier). Both high ( 1.27 millimeters per year) and low (less than 0.004 millimeter per year) rates of penetration have been published. This discrefancy requires further work if it is to be resolved; studies of irradiation and grain size effects should also be included. These studies are related to the use of lead as a main corrosion barrier material.

Relative1y high rates of corrosion have been reported for specimens of lead immersed at temperatures of 90 to $95^{\circ} \mathrm{C}$ in ground water believed typical of the ground water in the Yucca Mountain repository (i.e., water from well $\mathrm{J}-13$ in the vicinity of the site). If the available short-term data are linearly extrapolated to 1000 years, the predicted corrosion losses are 8 to 36 millimeters for the 1000 -year period. Although these rates are relatively high, a 125. millimeter thickness of lead (see later discussion on shielding) would offer protection against general corrosion for approximately 350 to 1550 years.

For intergranular corrosion, the dominant form of corrosion observed in archaeological specimens, no penetration rates are given in the literature, and the corrosion mechanisms are not yet understood, although grain size is known to play an important role. Further work would be needed to gain greater understanding of this type of corrosion in lead alloys and to assess its importance in designs employing lead.

Pitting of lead alloys has been reported for soil corrosion tests. Pits continued to propagate beyond 10 years and some pits reached depths of severa1 millimeters. These high pitting rates are of concern, but further work would be needed for more repository-like environments. 
For filler and liner applications lead would function as a secondary, not a primary, corrosion barrier. Besides being subject to corrosion itself, lead may increase the corrosion of the other components of the waste package or increase their susceptibility to embrittlement (See Appendix B). In this context, the effects of the presence of lead on the incidence of stress-corrosion cracking in other alloys is a matter of serious concern. Nickel-based alloys (including a leading candidate alloy for the Yucca Mountain waste package) are known to be susceptible to stress corrosion-cracking that is enhanced by lead. For designs employing lead in combination with other materials, a better understanding of the mechanisms and conditions that produce lead-enhanced stress-corrosion cracking and other forms of embrittlement would be needed. One design option that would mitigate the problem is to employ a canister to encase any lead components.

The rates of lead corrosion could be accelerated by electrical coupling between lead and any of the container or canister materials that are being considered. Quantitative data for galvanic corrosion effects in the expected environmental conditions would be needed for lead (or for any combination of metals) employed in the waste-package design.

Metals in contact with lead at elevated temperature (above approximately $175^{\circ} \mathrm{C}$ ) may become embrittled based on observations of solid lead/ metal couples involving steel alloys, beta brass, and tin bronze (Druschitz and Gordon, 1984). Steel, when coupled to solid lead, zinc, cadmium, tin or indium embrittled in short term tests down to about three quarters of the melting point (in absolute temperature) of each of those metals. Delayed failures have been observed at even lower temperatures (Lynn, et. a1., 1984). This phenomenon has been observed, for example, in steel and conper alloys in contact with solid lead at temperatures within the range expected for the repository. No adverse effects of hot lead alloys on Zircaloy have been reported. Candidate waste-package designs that contain lead would require extensive research and development to ascertain that embrittlement would not occur over the long term.

Although there is insufficient evidence to rule out the use of lead in conjunction with the candidate container materials now under consideration, the question of compatibility remains in the areas of stress corrosion, galvanic corrosion, and embrittlement. Furthermore, because of considerations such as these, the use of lead in a waste-package application could constrain the selection of the materials used in the other components of the waste package. In any event, a large research effort would be needed to generate sufficient data to dispel these concerns and provide adequate information for the license application to the Nuclear Regulatory Commission.

\section{B. Shielding from penetrating radiation}

Because of the common origin of decay heat and radiation phenomena--that is, the radioactive decay of the radionuclides in the waste-radiation levels are inextricably linked to the decay heat in the vicinity of the waste package. Thus, during the period when the decay rate is high, both the temperature and the radiation levels in the vicinity of the waste package will 
be high, although the amount of liquid whter in the vicinity of the disposal container will be very limited. Radiфlysis products and their yields in moist air are not well established. Effect of these on the waste package and the host rock are the subject of planned studies.

By the time temperatures are sufficiently low (because of the decreasing decay rates) to permit the presence of liquid water (albeit in very small quantities within the unsaturated zone), the radiation levels will be too low to result in significant radiolysis of the water. Thus, since radiolysis effects are not expected to be of major concern (this expectation, of course, will require confirmation during site characterization) and since radiation at the anticipated dose rates is expected to have little or no significant effects on either the host rock or the materials of which the waste package is constructed, there is little incentive to provide a waste-package component for the sole purpose of radiation shielding. Nonetheless, if the repository is subject to conditions that would allow water to reach the disposal container, then radiolysis products could be formed, and these products would be deleterious to the corrosion resistance of the container. For such a case, shielding would be of significant value.

Using lead (or any other dense material) as a shielding material in the interior of thin-walled containers with consolidated spent fuel provides a substantial reduction in the magnitude of the gamma dose rate outside the container (see Appendix $C$ for a more detailed discussion). In comparison with a thin-walled container without lead, the addition of a lead liner 1.25 centimeters thick within a thin-walled container, as in Figure 5 , reduces the dose rate by approximately 80 percent while adding approximately 1 metric ton to the total wight of the container. On the other hand, filling all of the internal void space reduces the dose rate by approximately 35 percent while adding approximately 3 metric tons to the total weight of the container (in addition to the weight of the lead liner). In terms of dose reduction per unit weight, it appears that adding a lead liner is preferable to filling the internal void spaces. However, other materials may be equally (or more) effective than lead in these applications and would also merit consideration.

In regard to the protection of repository workers from radiation, it should be noted that it has not been necessary to establish waste-package performance objectives for compliance with the repository design criteria for preclasure radiological safety (10 CFR Part 20, 10 CFR 60.131-60.133) because the principal means for protecting workers against radiation will be the use of specially shielded enclosures (e.g., hot cells) in the surface facilities of the repository, separate ventilation systems for areas in which waste is handled, specially shielded equipment (transfer casks and transporters) for moving the waste inside the surface facilities and in the underground repository, and shielded plugs in each waste-emplacement borehole. No reliance will be placed on the waste package itself for this purpose. 
C. Heat-transfer properties

Heat-transfer analyses for the wated package that would be used at the Yucca Mountain site have been performed. For spent fuel, the results show that the maximum spent-fuel temperature inside the waste package will be held below the design 1 imit $\left(350^{\circ} \mathrm{C}\right)$, which has been determined to be the maximum temperature that can be tolerated by the cladding of the spent fuel. The use of a filler material is an option that could replace or diminish reliance on the cladding for the control of radionuclide releases. If such a filler were used, a different set of design constraints might be adopted to prevent the filler material from remelting, for example. (Lead melts at $327^{\circ} \mathrm{C}$.)

A simplified thermal analysis of the potential advantages of using lead within the spent-fuel region has been conducted. The results indicate that casting lead into the spent fuel would lower the peak spent-fuel temperatures $\left(350^{\circ}\right)$ by approximately $25^{\circ} \mathrm{C}$ while adding approximately 3 metric tons to the weight of the waste package. The temperature reduction is due to the high conductivity of lead. It should be noted, however, that any other metallic fillers would be expected to provide a similar temperature reduction in comparison with a gas-filled container.

The analysis of a lead-filled annulus for designs that use a canister (e.g., the canister in which high-level waste is solidified) inside the disposal container has also been conducted. All radiation energy is assumed to be deposited in the waste package materials based on the large degree of self-shielding by the fuel itself. Predictions of the temperature drop across a lead-filled annulus were compared with results obtained for containers filler with helium or air. Not surprisingly, lead was shown to be a better heat-trarsfar medium than either gaz. If decreased package temperatures were desired, there would be some advantage to filling the gap with lead (or some other metal), as compared with helium or air.

\section{Mechanical properties}

The mechanical properties of lead and a lead alloy with antimony ( 6 percent) are tabulated in Appendix $D$. As already mentioned, the metal is soft, malleable, and easily abraded, and it creeps at low stress levels even at room temperature. With increasing temperature, the tensile strength rapidly deteriorates (see Appendix $D$ ) because of lead's low melting point $\left(327^{\circ} \mathrm{C}\right)$. Published data indicate that lead will show creep of 1 percent after 23 days at $150^{\circ} \mathrm{C}$ or after 3 hours at $250^{\circ} \mathrm{C}$.

The low mechanical strength, low creep resistance, and easy deformability of lead have prevented it from being considered as the sole containment barrier. Susceptibility to creep renders lead unsuitable for elevatedtemperature use where maintaining shape is important. Thus, there appears to be a world-wide consensus that lead is not suitable for use on the outside of the disposal container. Lead may be suitable as filler material or as a liner, where mechanical properties are less important. Lead or other filler materials would provide mechanical stability to the brittle fuel cladding 
during transport and emplacement operations, although there may not be much need for such internal support because the number of "leakers" that are expected to develop in the conceptual design case will be at very low levels (Gilbert, et. al., 1988).

The general issue of internal structural support by a lead filler is not very relevant in the conceptual design strategy because the external pressure will be only 1 atmosphere under the conditions expected at the Yucca Mountain site. However, if more severe conditions were to be addressed, lead could be useful as an internal support.

Another concern is the expansion of lead with temperature, which may generate internal stresses that may adversely affect performance and which must be allowed for in design. This would to some extent be true of any monolithic filler, depending on its coefficient of expansion and the dimensions of the waste package; lead, however, has a high coefficient of expansion and thus might present greater difficulties. Preliminary calculations indicate that the waste package internal stresses could be quite high; they could affect the integrity of the spent fuel, promote stress-corrosion cracking at the container welds, and promote hot-lead embrittlement of the container materials. A simple method of minimizing internal temperature induced stresses would be to leave a free space in which the lead could expand. Internal stresses have not been a problem in lead-shielded shipping casks where container walls are designed to be of sufficient thickness to withstand the build-up on any such stresses (personal communication from A. H. Wells, Nuclear Assurance Corporation, May, 1989).

A more complete discussion of lead as a structural material is given in Appendix D.

\section{E. Casting technology}

If a filler is to be used in the waste package, casting is one way in which a metal would be used in this application. However, regardless of the metal to be cast, many problems can be expected with casting a monolithic filler into a full-size disposal container. For example, the occurrence, detection, and gauging of voids are problems that would have to be addressed. Work in Sweden and Canada has shown considerable progress in minimizing void formation (see Appendix E). A specific problem with regard to lead is that the casting process may affect the corrosion resistance of lead because the control of grain structure and impurity segregation is difficult and these factors affect corrosion properties. However, if the DOE decides to evaluate fillers, lead will be included among the candidate materials to be evaluated. One advantage that lead possesses with regard to casting is its low melting temperature.

During the solidification of molten lead, the segregation of impurities and alloying elements may occur on both a microscale and a macro-scale. This may decrease corrosion resistance and promote intergranular attack. The 
directional cooling that is currently favored to prevent void formation tends to produce an oriented structure of large columnar grains, which may reduce resistance to intergranular corrosion along the direction of orientation. Over the long term, the best resistance to corrosion would be expected from lead with a fine-grained structure not obtainable through casting. Finally, because there is little to no wetting of the Zircaloy cladding during casting, voids and shrinkage gaps can be expected along fuel rods which may or may not be important to the desired function; for example, the voids and gaps may result in preferential pathways for the ingress of ground water or the escape of gaseous radionuclides, obviating to a large extent the secondarycorrosion-barrier and radionuclide-release functions of lead that may be desired. This would be true for any material considered as a filler material.

Casting is not the only way to obtain some features that might be desired from a filler. For example, lead shot might be used to fill voids (which might otherwise fill with water) to preclude nuclear criticality. It is also possible to use a preformed lead cavity (a liner) into which a waste canister can be lowered to provide shielding or corrosion-barrier functions. This is the option being considered by the CEC-sponsored Belgian program for cladding hulls. In addition, this option of filling the annular gap between the waste canister and the waste container with lead represents a more efficient use of lead for radiation shielding.

\section{F. Environmental releases and regulatory considerations}

The use of lead as a waste-package material requires consideration of its potential fo: release from the repository into the accessible environment, especially because of lead's adverse health effects (PHS, 1962; Snyder et al., 1971; NAS, 1977) and stability. In evaluating the use of lead in the waste package for a repository at Yucca Mountain, it will be necessary to determine whether the applicable regulatory requirements would be met.

In terms of regulatory requirements, lead is subject to the drinking-water standards promulgated by the U.S. Environmental Protection Agency (EPA, 1986) in 40 CFR Part 141; these standards are stated in terms of the maximum contaminant level that may not be exceeded. Although these standards apply to water entering the drinking-water distribution system, it would not be prudent to allow potential underground sources of drinking water to exceed these standards. For lead, the maximum contaminant level is 50 micrograms per liter, but the EPA is in the process of proposing (53 FR 31571, August 18, 1988) lower levels ( 5 micrograms per 1iter). In addition, as a result of inquiries in the past several months by state officials, the EPA is considering whether further rulemaking is necessary on the implications of the Resource Conservation and Recovery Act for the use of lead in the disposal of low level radioactive mixed wastes. 
In determining whether the EPA standards would be met, it is necessary to estimate the maximum concentration of lead (or any of its corrosion or oxidation products) that could reach the accessible environment. This requires estimating the amount of lead potentially available for transport from the waste packages and then determining the rate of transport to the accessible environment. Because the most likely mechanism for the transport of lead is via ground water, the maximum concentration of lead depends mainly on the solubilities of lead substances under the geochemical conditions present at the repository site and along pathways to the accessible environment. The calculations must account for both unsaturated and saturated environments as well as for several transport mechanisms (e.g., advection, diffusion, fracture flow); they must also account for the nonuniform, heterogeneous nature of the soil and the rock formations through which transport could occur. Unfortunately, insufficient information is available at present to adequately perform such calculations for the Yucca Mountain site. Until additional geohydrologic information is available from site characterization, it is not possible to calculate to any degree of certainty the concentrations of lead that may reach the accessible environment from a repository at Yucca Mountain.

For purposes of perspective, it is important to note here that the environmental concentrations of metals other than lead (particularly the heavy metals) are also of major concern to the EPA, and the problem of meeting the applicable regulatory requirements would apply to any metal in the waste package as well as to lead. Moreover, all actinides contained in the waste package (e.g., plutonium 239 and americium 241) eventually decay to a lead isotope.

Iead is considered to be geochemically immobile in soils (Rickard and Nriagu, 1978), and it is therefore expected that its concentration in ground water would be low. Generally, any lead dissolved from primary sulfide ore tends to react with carbonate or sulfate ions to form insoluble lead carbonates or lead sulfates. Elevated levels are found generally in areas where water has a low $\mathrm{pH}$ or high chloride concentrations (conditions not expected at Yucca Mountain) and relatively high temperatures (Lovering, 1980). Lead can be leached by organic acids and travel in solution as soluble lead organic complexes, but the amount of organic material in the underground environment will be insignificant in this context. Regions with alkaline, neutral, or saline waters and soils are expected to have little or no naturally occurring forms of lead in their ground water.

The results from analyses of data taken in vicinities of lead deposits and mines are ambiguous, but some discussion of this topic is included here as background information that may or may not be found to be relevant to the repository. Some deposits show soluble-total-lead concentrations at the limits of detection, while others show concentrations above 50 micrograms per liter. There are several municipalities whose drinking water comes from flooded abandoned lead mines. The concentrations of total lead in their raw water are less than 10 micrograns per liter. It should be noted that these mines are in the "New Lead Belt" of Missouri, where the background concentrations of lead in ground water of ten exceed existing or proposed EPA standards. However, the residence time of water in these mines is not long 
enough to conclude that soluble-lead concentrations would remain at the present low levels (i.e., below the maximum contaminant levels) over the long periods of interest to the safe isolation of radioactive wastes.

\section{G. Summary of properties}

The various investigations of lead have revealed several favorable and unfavorable attributes of lead as a component of the waste package. The favorable attributes include good resistance to general corrosion in some environments, ability to provide shielding from penetrating radiation (gamma rays), good thermal conductivity, impact resistance, and a low melting point, which is desirable for casting. These properties of lead are important in meeting the functional requirements of a filler or liner for a waste package.

The unfavorable characteristics of lead include the following: the potential for localized corrosion (intergranular corrosion, grain-size effects, galvanic corrosion, and crevice corrosion); low strength and susceptibility to creep; high thermal expansion; poor bonding to Zircaloy, the zirconium alloy that is commonly used in spent-fuel cladding, and the formation of slag on molten lead; the possible embrittlement of container mater-als; difficulty in achieving void-free castings, which could be important to structural support, corrosion protection, shielding, and heat transfer; possibility of melting in the center of the package; and high density, which increases handling costs because of the weight. Some of these problems may not be important if, for example, only a waste-stabilizing function is needed. This is the approach taken by the Swedish program. Another way of avoiding the problems associated with casting is to use a preformed lead liner insice the-disposal container. This is the approach taken in the CEC-sponsored Belgium program for the disposal of cladding hulls. Concerning the potential toxicity issue, insufficient geohydrologic information is available to determine the concentration of lead (or any other metallic element) that may reach the accessible environment from a repository at Yucca Mountain.

Appropriate test programs to address technical concerns with respect to lead, such as those discussed in the preceding text, would be considered as a part of further studies of lead in the alternative-concepts program. It is obvious from the above discussions on the properties of lead that the available technical data are insufficient, and an extensive research and development effort would be necessary to qualify lead for use in the waste package for the Yucca Mountain site if site characterization proves conditions to be more severe than those expected for the conceptual design approach. An outline of such a development effort is provided in Appendix $F$.

\section{H. Costs of using lead fillers or liners}

Any additional components added to the conceptual design (i.e. for the dimensions in Figure 2) will increase costs regardless of the material or materials used. All costs of using lead filler and/or liner materials in 
several types of waste package have been estimated for a repository at Yucca Mountain (see Appendix F). These estimates are based on the void space in the waste package, the current cost of lead, and a total of 114,282 assemblies of PWR spent fuel and 130,404 assemblies of BWR spent fuel. The assumptions about the numbers of spent-fuel assemblies are based on the statutory limit $(70,000$ metric tons of heavy metal) on the quantity of waste that may be disposed of in the first repository until the second repository begins operations and on a forecast (DOE, 1988c) of the spent-fuel types the DOE expects to receive.

Three design configurations were considered: packages for consolidated spent fuel, packages for nonconsolidated (intact) spent fuel, and hybrid packages. Potential configurations for consolidated-fuel and nonconsolidated-fuel packages are shown in Figure 2. The hybrid container configuration is designed to accommodate the mix of PWR and BWR assemblies to be received at the repository; it accommodates three intact PWR assemblies and four intact BWR assemblies in a disposal container with a diameter of 28 inches. For 27,359 packages of consolidated fuel, the cost of lead filler is estimated at $\$ 170$ million. For 59,828 packages of nonconsolidated fuel, the cost is about $\$ 730$ million, and for 38,794 hybrid packages, the cost is about $\$ 500$ million (Appendix F). The numbers of packages were estimated on the basis of the design concept included in the SCP conceptual design and the above-stated assumptions about the numbers of spent-fuel assemblies.

Other costs associated with the use of lead as a filler are estimated at $\$ 50$ million for lead-processing equipment and $\$ 50$ million for handling (personal communication from M. J. Hadwin, Federal Industrial Services, Inc., Norember 1988). The basic cost for 27,359 consolidated packages not ccntaising lead is about $\$ 660$ million and emplacenent costs total about $\$ 840$ million (DOE, 1988d), for a total of $\$ 1.5$ billion. This total for packages containing lead fillers (consolidated case) is therefore about $\$ 1.8$ billion, or about 20 percent more. Costs for the nonconsolidated fuel packages and the hybrid consolidated packages would be commensurately higher.

Assuming a fixed container size (i.e., the conceptual design dimensions) the cost of a liner 1.25 centimeters thick is roughly estimated at $\$ 2500$ per container (personal communication from M. J. Hadwin, Federal Industrial Services, Inc., November 1988 ), or about $\$ 68.4$ million for 27,359 containers. An increased number of packages (about 5 percent more) would be required to make up for the space occupied by the lead liner. An additional 1370 packages (i.e., 5 percent) with lead liners would cost about $\$ 78.4$ million ( $\$ 75$ million for additional container and emplacement costs based on the $\$ 1.5$ billion cost estimate, and $\$ 3.4$ million for the 1 iners), which, when added to the $\$ 68$ million, represents an increase of about 10 percent over the costs for containers without lead.

While the above costs appear to be high, it should be noted that lead is readily available and is relatively low in cost (especially in comparison with some of the other alternative materials 1 isted in Table 2 ). 
Finally, developmental costs for any material will be substantial. In the case of lead, these developmental costs as estimated by DOE (see also Appendix F), indicate an estimated $\$ 9$ million for research and development would be needed by OCRWM to resolve the technical concerns about using lead in the waste package. This work would require about 5 years to complete.

\section{APPLICATION OF LEAD IN THE U.S. REPOSITORY PROGRAM}

\section{A. Application in the conceptual design waste-package strategy}

As discussed above, the conceptual design waste-package compliance strategy and the conceptual design as described in the Site Characterization Plan for Yucca Mountain were developed to meet the regulatory requirements of substantially complete containment and the subsequent gradual release of radionuclides under the conditions expected at the Yucca Mountain site. Under this strategy, only two waste-package components (the thin-walled, corrosion-resistant container and the waste form) are assumed to be necessary, in conjunction with the expected environmental conditions, to show compliance with the regulatory requirements.

The application of lead or its alloys as the metal barrier in the conceptual design strategy has been considered. From the discussion above and in Appendix $B$, it is apparent that there are many uncertainties about the potential corrosion performance of lead in the environment of the Yucca Mountain site--uncertainties that could be resolved only through extensive testing and evaluation. The use of lead as the metal-barrier material does nct appear to offer any distinct corrosion-resistance advantages in comparison with the candidate materials under consideration in the conceptual desigis program (austenitic stainless steels, a high-nickel alloy, copper, and alloys of copper). In addition, lead and its alloys are generally inferior from the standpoints of mechanical strength and creep resistance and are considered to be inferior to the conceptual design alloys under consideration. Therefore, lead is considered unsuitable for application as the single metal barrier in the conceptual design strategy.

Several other potentially beneficial uses for lead are discussed in the preceding section and in the appendixes. In the conceptual design strategy, these applications would envision lead being used as an additional component in conjunction with the conceptual design. Among the functions that lead might provide are additional corrosion barriers, improved heat-transfer capabilities, radiation shielding, and internal structural support for the container. In all of these applications, the use of lead in conjunction with the other materials in the container and in the waste form introduces new technical concerns that would require extensive testing and analysis to provide the information necessary for licensing and which would likely constrain the selection of otherwise preferred materials. Because the conceptual design requires none of the functions offered by lead and because any benefits that might accrue from the incorporation of additional lead components would be achieved at the expense of the addition of significant new uncertainties about long-term performance, no further consideration of the use of lead in the conceptual design strategy appears to be warranted. However, lead may have a role in alternative designs. 
B. Applications of lead in waste-package alternatives

As previously discussed, the DOE is planning to evaluate alternative design concepts and materials choices to assess waste packages with improved isolation capabilities (i.e., longer containment or lower radionuclide-release rates). The alternatives that will be evaluated must provide enhanced capabilities for repository conditions more adverse than those currently expected: greater than expected quantities of water, a more aggressive than expected water chemistry, and higher than expected external mechanical loads. The use of these alternatives would entail using additional components and alternative materials to provide many of the functions identified above with the potential uses of lead. In many of these applications, lead and lead alloys may be viable candidates that could receive consideration along with other viable candidates in a logical, disciplined selection process: The process to be followed in the evaluation and selection of alternatives is described in the Site Characterization Plan for the Yucca Mountain site (DOE, 1988a). Appropriate testing programs to resolve issues related to the performance of lead in these applications will be developed as indicated as the evaluations of alternatives proceed.

\section{SUMMARY AND CONCLUSIONS}

- Lead has received some consideration as a material for use in waste packages in the United States and other countries.

- Although many results of the international studies of lead are somewhat useful in assessing the applicauility of lead for the Yucca Mountain reposicory, none of the foreigi designs is directly applicable because of the generally much higher temperatures and significantly different environmental conditions that are expected to prevail at the Yucca Mountain Site.

- In the context of the conceptual design strategy for demonstrating regulatory compliance for the waste package, lead would be an inappropriate material for use as the principal containment barrier in comparison with any of the candidate materials currently under consideration primarily because of the poor mechanical and creep properties. Therefore, no further consideration will be given to the use of lead in the conceptual design. (SCP, 1988 details the conceptual design).

- In the context of the alternative materials and designs that the DOE plans to consider to account for site conditions that are not expected but may warrant consideration because of site-characterization results or the licensing process, lead offers characteristics and performance that could be useful. The DOE has identified lead as a material to be evaluated in the currently planned alternative-concepts program. Lead may provide additional corrosion barriers, improved heat transfer capabilities, radiation shielding, and internal structural support for the container. The DOE will give lead appropriate consideration, along with other viable alternative materials and design concepts, 
with the realization that an extensive research effort will be required to address the many technical concerns raised in this report. At present the available technical data on the performance of lead in potential applications for the waste package that would be used at the U.S. repository (Yucca Mountain, Nevada), are limited and insufficient to suggest a preference for lead over other materials. 
Arup (Ove Arup and Partners), 1985. Design Study on Containers for Geological Disposal of Hi.gh-Level Radioactive Waste, EUR9909EN, Commission of European Communities, Brussels, Belgium.

Bonne, A., and Manfroy, 1986. "Factors Involved in Updating the Concept of a Repository for HLW, ILW, and Alpha-Bearing Wastes in a Deep Clay Formation on Land," in Proceedings of an International Symposium on Siting, Design, and Construction of Underground Repositories for Radioactive Wastes, International Atomic Energy Agency, Vienna, Austria.

Cohen, J. J., D. G. Coles, and L. D. Ramspott, 1981. "Lead Encapsulation of Nuclear Waste: A Risk Assessment," in Transactions of the American Nuclear Society, Vo1. 34, pp. 350-351.

Couture, R., 1985. "Steam Rapidly Reduces the Swelling Capacity of Bentonite," Nature, Vol. 318, pp. 50-52.

DeMicheli, S. M. et al, "Uso all Plomo en Contenedover de Residuos Radioactivos de Alta Actividad," IAEA-SM-289/22 p. 449, International Atomic Energy Agency, Vienna, Austria, 1986.

DOE (U.S. Department of Energy), 1984. "General Guidelines for the Recommendation of Sites for the Nuclear Waste Repositories," 10 CFR Part 960, Federa1 Register, Vol. 49, No. 236.

DOE (U.S. Department of Energy), 1988a. Site Characterization Plan, Yucca Mountain Site, Nevada Research and Development Area, DOE/RW-0199, Washington, D.C.

DOE (U.S. Department of Energy), 1988b. Site Characterization P1an Overview, Yucca Mountain Site, Nevada Research and Development Area, Nevada, DOE/RW-0198, Washington, D.C.

DOE (U.S. Department of Energy), 1988c. Integrated Data Base for 1988: Spent Fuel and Radioactive Waste Inventories, Projections, and Characteristics, DOE/RW-0006, Rev. 4, Washington, D.C.

DOE (U.S. Department of Energy), 1988d. Characteristics of Spent Fuel, High-Leve1 Waste, and Other Radioactive Wastes Which May Require Long-Term Isolation, DOE/RW-0184, Washington, D.C., Vol. 1.

Druschitz, A. P. and P. Gordon, 1984. Solid Metal-Induced Embrittlement of Metals, in Embrittlement by Liquid and Solid Metals, edited by M. H. Kamdar, publication of the Metallurgical Society of AIME, 1984 (Proceedings of Meeting in St. Louis, October, 1982).

EPA (U.S. Environmental Protection Agency), 1986. National Primary Drinking Water Regulations, 40 CFR Part 141. 
Gilbert, E.R., W. J. Bailey, A. B. Johnson, Jr., 1988. Results of Studies on the Behavior of Spent Fuel in Storage, Journal of the Institute of Nuclear Materials Management, Vo1. XVI, No. 3, April.

Knecht, B., and C. McCombie, 1986. "High-Level Waste Overpack for Final Storage in the Swiss Granite Bedrock: Materials Selection, Design, and Characteristics," in Proceedings of an International Symposium on High-Level Nuclear Waste Disposal, Battelle Press, Columbus, Ohio, pp. 533-544.

Lovering, T. G., editor, 1980. Lead in the Environment, U.S. Geological Survey Professional Paper 957, Washington, D.C.

Lynn, J. C, and W. R. Worke, 1984. Delayed Failure of Steel Due to Solid Metal Induced Embrittlement, in Embrittlement by Liquid and Solid Metals, edited by M. H. Kamdar, publication of the Metallurgical Society of AIME, 1984 (Proceedings of Meeting in St. Louis, October 1982).

Merz, E., et a1., 1986. "Implementation of the Federal Republic of Germany's Strategy of Radioactive Waste Disposal, in Proceedings of an International Symposium on Siting, Design, and Construction of Underground Repositories for Radioactive Wastes, International Atomic Energy Agency, Vienna, Austria.

NAS (National Academy of Sciences), 1977. Drinking Water and Health, Washington, D.C.

NRC (U.S. Nuclear Regulatory Commission), 1988. "Disposal of High-Leve1 Radioactive Wastes in Geologic Repositories," Code of Federal Regulations, Title 10, Part 60.

Ogard, A. E., and J. F. Kerrisk, 1984. Groundwater Chemistry Along Flow Paths Between a Proposed Repository Site and the Accessible Environment, LA-10188-MS, Los Alamos National Laboratory, Los Alamos, N. M.

Marsh, G. P. et al., "Corrosion Assessment of Metal Oropochs for Radioactive Waste Disposal", European App1. Res. Rept.-Nuc1. Sci. Techno1., Vo1. 5, No. 2, p 223-252.

PHS (U.S. Public Health Service), 1962. Public Health Drinking Water Standards, USPHS Publication 956.

Rickard, D. T., and J. 0. Nriagu, 1978. "Aqueous Environmental Chemistry of Lead," The Biogeochemistry of Lead in the Environment, J. 0. Nriagu, editor, Elsevier/North Holland Biomedical Press, Amsterdam.

SKBF/KBS, 1983. Final Storage of Spent Nuclear Fuel--KBS-3, Swedish Fue1 Supply Company, Division KBS, Stockholm, Sweden.

Snyder, R. B., et al., 1971. A Study of Environmental Pollution by Lead, State of Illinois, Institute for Environmental Quality, Report I IEQ71-7. 


\section{INTRODUCTION}

Lead has been or is being analyzed as a waste-package component in the waste-management programs of Sweden, Canada, Argentina, the United States, the Federal Republic of Germany, Switzerland, and the United Kingdom. In addition, the Commission of the European Communities (CEC) is sponsoring a program in Belgium. Information on these programs has been gathered from the general literature, a presentation to the DOE's Peer Review Panel on Lead (Schneider and Bradley, 1988), and several direct communications.*

The attention that lead has received has been focused on its potential use as a matrix material for embedding vitrified waste and irradiated cladding hulls and as a material for filling the void spaces in waste canisters and in waste containers or as a layer in the annulus between the canister and the container. Because of its poor mechanical properties, lead has received no attention as a potential structural material for radioactive-waste canisters or containers.

\section{EVALUATIONS IN THE UNITED STATES}

Though lead is not at present a candidate waste-package material in the DOE's repository program, for the conceptual design, it has been included in the 1ist of materials for the alternative concepts. A few studies have investigated the use of lead and its alloys as filler materials.

The first comprehensive evaluation of lead as a waste-package material was performed on behalf of the Nuclear Regulatory Commission (NRC) in 1979.

*The DOE received personal communications from $P$. E. Ahlstrom and $L$. Werme, Swedish Nuclear Fuel Supply Company, on the Swedish program, September 20, 1988; E. Detilleux, ONDRAF (National Institute for Radioactive Waste and Fissile Materials), on the Belgian program, October 4, 1988; W. T. Hancox, Atomic Energy of Canada Limited, on the Canadian program, October 20, 1988; C. McCombie and I. McKinley, NAGRA (National Cooperative for the Disposal of Radioactive Waste), on the Swiss program, September 23, 1988; E. Pala, CIOS, on the Argentinian program, October 4, 1988; and H. Roethemeyer, PhysikalischTechnische Bundesanstalt, on the program in the Federal Republic of Germany, September 23, 1988. In addition, the DOE received personal communications from D. Alexandre, Commissariat a 1'Energie Atomique, October 4, 1988, and R. H. Flowers, United Kingdom Atomic Energy Authority, September 27, 1988, on the status of lead in the French and the British programs, respectively. 
The report, issued jointly by the National Academy of Engineering (NAE) and the National Academy of Sciences (NAS), evaluated lead as a candidate matrix material in which radioactive waste in the form of glass pellets, calcine, or spent-fuel elements would be encapsulated (NAE/NAS, 1979). Lead was evaluated in comparison with aluminum and titanium. Other materials were discarded outright because of inadequate corrosion resistance (iron, zinc) or because of potential strategic shortages (copper-based alloys). The report suggested the use of aluminum-based alloys as matrix materials for the three types of waste. Isostatically compacted titanium was also suggested for spent fuel.

In the same report, lead alloyed with 0.06 percent copper was reported to have excellent corrosion resistance for temperatures up to $100^{\circ} \mathrm{C}$ in solutions of both low and high ionic strength. It was also found to have adequate heat conductivity, excellent impact resistance, low reactivity with silicon dioxide, and a relatively low cost per unit mass. However, it was said to have some serious drawbacks. First the volume, rather than the mass, is significant in the proposed application, and lead is considerably more expensive on a cost-per-unit-volume basis than on a cost-per-unit-mass basis. Second, strategic shortages of lead were projected by the year 2000; these would result in higher costs even with greater projected recycling. Third, the low melting puint of lead presents the possibility of center melting accompanied by reaction with the dispersoid, and the possibility of mechanical instability because of creep. If the container were breached, creep could lead to seizure of the material in the waste-emplacement borehole causing problems in retrievability. Finally, because of its greater density, lead would present more of a transportation problem than would other metals (though its ability to act as a gamma-radiation shield would be advantageous). However, all of these objections need io be critically reviewed in the light of updated information. For example, lead shortages may not occur.*

A Westinghouse research report was also issued (Fish et al., 1982) on the screening of candidate filler materials in DOE's spent-fuel waste packages. Screening was based on the ability of the candidate materials to be emplaced at less than $650^{\circ} \mathrm{C}$, on their ability to minimize shrinkages and voids after filling, on the extent of their interaction with the spent-fuel cladding, on their ability to release less than 1 percent moisture on heating to $300^{\circ} \mathrm{C}$, and on minimizing the release of gas on heating. As a result of screening tests, which did not involve actual waste, lead containing 1 percent antimony and zirconia were the materials recommended for further testing for package designs contemplating a filler material.

* Lead is an important strategic and critical metal primarily because both military and civilian sectors rely on lead-acid batteries (Woodbury, 1983). Lead is listed in the National Defense Stockpile, which is administered by the Federal Emergency Management Agency (FEMA). The stockpile goal for lead is 998,000 metric tons, and the current inventory is 545,000 metric tons (FEMA, 1988). However, the Bureau of Mines reports that lead "does not have a high potential for supply disruption" (Woodbury, 1985). The Bureau's forecasts of supply and demand in the year 2000 indicate that even under an acceleratedeconomic-growth scenario there would be no significant reliance on imports. Only in the highest-demand scenario (i.e., a demand forecast of 2.2 million metric tons), which the Bureau considers unlikely, would additional domestic capacity or foreign imports be required. 
The Westinghouse screening program also measured the relative corrosion potential between lead and cladding and container materials in reference ground waters for the salt, basalt, and tuff sites at room temperature. The results of these tests indicate that, when galvanically coupled, the lead alloys corrode preferentially to 304 stainless steel, TiCode-12, Inconel 625, and Incoloy 800. In tuff ground water, the corrosion of Zircaloy-4 is only slightly preferred with respect to lead. Galvanic coupling is important, as the corrosion rate of the anodic metal can be much higher than that in the uncoupled case. This has been shown experimentally in the Argentinian and Canadian research (De Micheli, 1986; Mathew, 1987). Galvanic coupling could also contribute to localized corrosion and stress-corrosion cracking (Merz, 1982). This might indeed have been observed in recent experiments in Canada (Mathew, 1987).

In recent years (1983-present), the International Lead Zinc Research Organization (ILZRO) has sponsored scoping tests on lead (Guenther, 1984a,b; 1985a,b; 1986; Pitman, 1987; Westerman et. al., 1988). This research has focused on the corrosion properties of lead, per se, in salt, basalt, and tuff ground water. The initial experiments for tuff environments were run at $55^{\circ}$ and $90^{\circ} \mathrm{C}$. The 1986 report indicates that "corrosion rates for $\mathrm{Pb}-1.6 \% \mathrm{Sb}$ are probably low enough for use as a matrix material in a waste package located in a tuff environment, although wther lead materials may also be acceptable depending on the exposure temperature and time." ILZRO also indicated that "...scoping tests on the transport of lead in ... tuff environments and initial evaluations of lead toxicity remain as important but unanswered concerns." A more recent report (Pitman, 1987) shows that, for $\mathrm{Pb}-1.5 \% \mathrm{Sb}$ and $\mathrm{Pb}-1.6 \% \mathrm{Sn}$ in the aqueous environment simulating tuf $\mathrm{f}$ conditions, cussiderable scatter in the data preclude reaching a conclusion that corrosion rates decrease with time. In the case of "curruding lead," corrosion rates actually increase with time after an early decline (see also Appendix B). Finally, in the most recent results for $100^{\circ} \mathrm{C}$ and $150^{\circ} \mathrm{C}$ tests (Westerman et al, 1988), the authors conclude: "corrosion rates observed in these short term tests were low enough to preclude elimination of lead as a waste package material solely on the basis of an anticipated high rate of general corrosion..."

Two studies have been published on the effects of lead on the leaching of simulated vitrified waste. The results are inconclusive. In one of these studies (Barkatt, 1984), lead was found to have little effect on glass leaching. The results of the other study (Lehman, 1985) indicate that lead and lead monoxide inhibit glass leaching, whereas lead dioxide greatly increases leaching. The results of Lehman's study are presently being reassessed, as it was found that the reported data differ by up to two orders of magnitude from the data originally presented to the sponsoring organization (ILZRO). One reference (Buckwalter, 1982) asserts that lead protects vitrified waste from aqueous corrosion. It also notes that the "concentration of lead in solution in a lead test cell containing the waste glass rose to levels of about $10^{-3} \mathrm{M}$, in excess of that predicted by solubility data of $10^{-4} \mathrm{M}$ at $25^{\circ} \mathrm{C} . "$

No study has been conducted in the United States on the effects of lead on the leaching of spent fuel, and if designs employing lead components were considered, such studies would be necessary. 
Of the waste-package designs being considered in Sweden, two are based on a copper container with walls 10 centimeters thick (SKBF, 1983). Spentfuel assemblies will be loaded directly into the container. In one design the loaded container is filled with molten high-purity lead, after which a tight-fitting 1 id is welded on. In the other design the container is filled with copper powder and a lid is placed on, after which the package is treated in a furnace for hot isostatic pressing. Both methods are considered to be feasible.

In the Swedish design lead plays the role only of a stabilizer to maintain fuel emplacement geometry. No credit is sought for corrosion, structural, thermal, or radiation performance or for any auxiliary function (Zausnica, 1985; SKi, 1984). Accordingly, performance analyses do not take into account the presence of lead (SKBF, 1983).

In the past the Swedes had considered a thin-walled titanium container with a 10-centimeter lead layer inside (Mattsson, 1978; Ekbom et al., 1980), but later abandoned this concept. At the time, it was felt that the lead layer could provide up to 4,500 years of corrosion protection under the conditions at the Swedish disposal site--namely, low temperatures (below $75^{\circ} \mathrm{C}$ ) and a limited availability of oxygen, but some sulfate (which is a known inhibitor of lead corrosion) (SKBF, 1978). Under the same conditions, the present copper canister is thought to be able to last up to a million years. A long-lasting container may be the reason why lead toxicity is not mentivileu in the KBS-3 (SKBF, 1983) study.

The Swedes have directed their lead program toward developing filling techniques with molten lead (Nordesjo, 1978; Werme, 1985). Two casting techniques have been studied in half-scale tests with simulated fuel rods. The first technique uses a two-step casting procedure based on radial cooling; the second uses a single-step procedure to control the cooling rate along the axis of the cylinder. Both techniques result in $98.5-99 \%$ filling of the container. The void space is located primarily between the copper container and the lead matrix in the radial-cooling procedure and between the simulated fuel rods and the lead matrix in the axial-cooling procedure. This may be relevant for heat transfer within the waste package and ultrasonic testing of the casting, as pointed out by the Canadian program (next section).

The Swedish design is not very relevant to the DOE's program because the reference environment is very different from the environment at Yucca Mountain, although their experience with the casting of lead is relevant.

\section{LEAD IN THE CANADIAN DESIGN}

In Canada the reference concept is a thin-walled container that requires internal structural support (Nuttall et al, 1983). The "supported-she11" design contemplates two possible configurations requiring (1) support by a low-melting-point metal matrix (lead) or by a nonmetallic particulate placed around the fuel bundles or (b) internal support by carbon-steel tubes into 
which the fuel bundles would be sealed. Packed particulates would fill the space between the tubes and the outer container. The main corrosion barrier would be provided by the thin-walled container (titanium, copper, or other metal) whose target lifetime is 500 years (Nuttall et al., 1983; Hancox, 1986, Johnson et al., 1987).

The Canadian program for metal-matrix selection has evaluated the relative merits of pure lead, lead alloys with 1 and 6 percent antimony, pure zinc, and aluminum-7 percent silicon. Pure lead and zinc were recommended as preferred candidates because of several beneficial casting properties. Pure lead was shown to have far better corrosion resistance than the other alloys in the saline solution simulating the ground water of the region considered for the Canadian repository site (Mathew, 1986a).

The Canadians have also run a series of lead-casting experiments. In one cooling scheme, without spent fuel in the cavity and with relatively small samples, they found that voids could be prevented from forming. However, there was a small shrinkage gap between the container metal (304 stainless steel in this experiment) and the lead. This air gap would control the rate of heat transfer (Mathew, 1.985). It was also determined that preheating the fuel to at least $330^{\circ} \mathrm{C}$ (lead melts at $327^{\circ} \mathrm{C}$ ) would prevent premature solidification of the lead. In a later set of small-scale experiments, an unirradiated $37-e l e m e n t$ bundle was especially prepared for casting. The fuel bundle was preheated to about $380^{\circ} \mathrm{C}$, and a multidirectional cooling scheme was used. A void-free cast was obtained. Other experiments with unfilled cavities showed that the new multidirectional-cooling technique would consistently reduce the casting time by one-half. The shrinkase gap, however, is not eliminated and hinders the witrasonic inspection of the casting.

Because of this, consideration is being given to a fast neutron-transmission technique (Montin, 1987). The technique appears to be in its infancy and will require extensive research and development if selected.

Under the sponsorship of the International Lead Zinc Research Organization, scoping tests have been recently conducted on lead corrosion in the presence of ASTM Grade 2 titanium and OFE-copper in Canadian and British granitic ground waters containing bentonite and sand covering a range of conditions expected in a radioactive-waste disposal vault (Mathew, 1987). "A comparison of the overall corrosion rates determined from coupon tests with those measured in the presence of container materials and bentonite shows corrosion acceleration indicating a strong galvanic effect." "The results also show that the lead corrosion rate increases with increasing ionic strength, temperature, and oxygen content of the groundwater solutions." Accelerated localized galvanic attack was also observed at the titanium/lead interface in a second series of experiments. In these experiments one lead specimen suffered intergranular attack and cracking. On the basis of the first series of results, Mathew (1987) extrapolated that a 25-mm layer of lead would provide at least 860 years of corrosion protection in Canadian waters. This extrapolation did not factor in important aspects of lead corrosion. Some of these had been noted previously--namely, the degree of micro- and macro-segregation of impurities and alloying elements during casting (Mathew, 1986b). 
The Canadians have indicated that lead corrosion may help inhibit the leaching of uranium dioxide in aqueous carbonate (McKay, 1985). In this environment lead would not passivate completely. During the corrosion process, it would lower both the redox potential and the carbonate concentration of the ground water, thus providing a less severe environment for leaching. No experimental studies to demonstrate this concept have been documented.

The Canadian casting and heat-transfer studies are of interest to the DOE program, but the corrosion studies are not directly relevant.

\section{LEAD IN BELGIAN STUDIES SPONSORED BY THE COMMISSION OF THE EUROPEAN COMMUNITIES}

The CEC-sponsored studies have been essentially devoted to investigating the use of lead as a matrix material for cladding hulls and beads of vitrified waste (Hebel, 1985).

The work on embedding of the hulls has been in progress since 1976. Lead would be used to retard leaching of the hulls in the event of container failure. Accordingly, experiments have been run to determine (a) the degree of wetting of oxidized Zircaloy-4 and other materials by lead alloys, (b) the corrosion resistance of the embedment alloys, and (c) the effects of lead alloys interaction with the various components of the waste. The findings are as follows: (1) Some slagging occurs during casting of the embedment alloys, $\mathrm{Pb}-1.5 \%$ ib and $\mathrm{Pb}-4 \% \mathrm{Sn}-12 \% \mathrm{Sb}$. "Particulate contaminaticr thus accumulates on top of the solidified alloy, compromising the use of this embedding technique because the removal of the slag necessarily involves secondary waste treatment" (2) The inner urano-zirconates ceramic layer "is transformed by the action of the molten alloy in such a way that radionuclides formerly insoluble in nitric acid are now easily dissolved in natural waters. This phenomenon has been consistently observed for the cesium isotopes and to a lesser extent for other fission products such as ${ }^{106} \mathrm{RU}$ and ${ }^{14}{ }^{4} \mathrm{Ce}$." The leach rate of the actinides, however, does not seem to be affected by the presence of the lead matrix (3) "Wetting of irradiated Zircaioy... is poor to nonexistent," therefore "the volume retraction during the solidification of the alloy is likely to yield a shrinkage gap between the surface of the embedding alloy and the waste itself" (4) 16-month corrosion tests in clay waters at 25 and $50^{\circ} \mathrm{C}$ showed that corrosion proceeds very slowly and that the reaction layer is on the order of a few microns at the end of the experiment ( $\mathrm{De}$ Regge, 1985).

On the basis of the above results, a new concept was developed which envisages the use of lead not in direct contact with the hul1s. In the new concept the hulls are first compressed in a high pressure die to be formed into compacted disks and then are introduced in a stainless steel canister. The sealed canister is then transferred into an overpack consisting of an interior lead container that fits into an outer stainless steel casing. The feasibility of this waste conditioning procedure was demonstrated on a pilot scale in mock-up conditions (SCK/CEN, 1986a). The active demonstration of the hull compaction and encapsulation technology in a hot cell was to be 
carried out shortly (SCK/CEN, 1986b; 1987). In the reference environment of wet clay at roughly $50^{\circ} \mathrm{C}$ a $10-\mathrm{mm}$ layer of lead is thought to resist 3,000 years under general corrosion attack (DeRegge, 1986). Maintenance of the grain structure and grain size of lead at the weld is indicated to be an important factor to ensure sufficient resistance against intergranular corrosion.

Prior investigations within the CEC program have studied the potential of hot metal embrittlement of steel and the variation of the thermal conductivity of compacts of lead plus cladding hulls with temperature (Hebel, 1982). It was found that impurities in the $\mathrm{Pb}-1.5 \% \mathrm{Sb}$ alloy, such as $\mathrm{Ag}, \mathrm{Zn}$, $\mathrm{Cd}$, and $\mathrm{Cu}$, would cause grain-boundary attack on AISI 304 steel. Prolonged treatment ( 9 and 16 months) at $100^{\circ} \mathrm{C}$ "led to a considerable increase of the extent of attack resulting in complete grains being detached from the stainless steel matrix." In subsequent tests with a purer alloy composition this attack was not observed. Mechanical tests were also carried out on lead coated candidate container materials at 553 and $563 \mathrm{~K}$ on the basis of information in the literature indicating potential embrittlement due to lead from about three quarters and upward of the lead melting temperature (Lynn, 1975). No difference was found between mechanical properties of coated and uncoated materials. In view of the present status of the hulls encapsulating program, the latter results must have convinced the CEC that lead induced embrittlement is not a problem at the low temperatures envisaged in their program.

The apparent conductivity of compacted Zircaloy embedded under vacuum in Fi-i.5\% Sb alloy was measured botween 30 and $70^{\circ} \mathrm{C}$. The values obtained show a linca= relationship with temperature and are 10 with respect to the thermai conductivity of both $\mathrm{Zr}-2$ and lead. This is believed to be due to the heat transfer resistance of contact gaps in the compact.

The Belgian work is not relevant to the U.S. program with regard to their corrosion experiments because of the different environmental

conditions, but the experience with casting on irradiated claddings is unique and relevant to the U.S. program.

\section{LEAD IN THE ARGENTINIAN DESIGN}

The Argentinian nuclear program contemplates the reprocessing of the spent fuel. The vitrified waste is to be encased into a thin walled stainless steel canister. The canister would be placed inside a 10-cm thick lead liner within a thin-walled container (Palacios et al., 1983). The container material has not been selected yet. Lead, however, is one of the principal components of the waste package and the main corrosion barrier to ensure isolation of the radionuclides for about 1,000 years (De Micheli et al., 1986). In addition, the Argentinian program is planning to use a lead alloy for embedding cladding hulls.

The Argentinians have recently initiated a research program to assess the corrosion behavior of lead in media simulating repository conditions. In their experiments the temperature never exceeded $80^{\circ} \mathrm{C}$, the maximum expected 
temperature in their repository. Especially interesting are the results of galvanic corrosion tests. These confirm that lead is anodic to AISI 304 stainless steel and to TiCode-2 in crystalline rock groundwater. "The corrosion velocity is considerable and depends strongly on the ratio of the exposed areas." In the case of carbon steel "The couple Pb-SAE 1010 followed a different behavior. At ambient temperature lead acted as a cathode; at $75^{\circ} \mathrm{C}$ an inversion takes place in a few days and lead starts acting as anode" (De Micheli, 1986).

As regards general and localized corrosion, the Argentinians concluded that, in the underground waters that had been utilized, "...pure lead (99.999\%) showed a good corrosion behavior to $80^{\circ} \mathrm{C}$. In these naturally aerated media the measured corrosion rate was of the order of microns per year, which coincides with available data in seawater and in archeological pieces. In underground waters saturated with oxygen...the corrosion rate was increased tenfold."

The study also found that "Lead corrosion was affected mainly by the concentration and types of salts present. In very low salinity media or in the presence of salts that result in soluble lead corrosion products, the corrosion velocity is very high and unacceptable for the proposed design. The presence of bentonite in suspension has beneficial effects in that it limits considerably lead corrosion even in very aggressive media. In these media the danger of localized attack undoubtedly exists."

The relevancy of the Argentinians design to the U.S. program is very limited because of the very different environmental conditions.

\section{LEAD IN THE GERMAN DESIGN}

The German program has successfully embedded beads of vitrified waste in a lead matrix. By May 1986, the German PAMELA facility at the Eurochemic site in Belgium had produced 818 tons of glass pellets embedded in $100 \mathrm{blocks}$ made of a continuous lead matrix (Lutze, 1987). The bead-production process has since been abandoned, and the bead-production unit has been dismantled.

The Germans have provided several reviews of the archeological corrosion record of lead for extrapolation to waste package applications (Krysko 1976, $1980,1983,1985)$. These reviews indicate that over the medium term (150 years) and the long term (several centuries) lead corrosion in various environments is dominated by intergranular attack. The attack is greater the coarser the grain size of lead and it is deepest along columnar grains perpendicular to the lead surface. On the basis of his extensive literature review, Krysko suggests four criteria that must be met in order for lead to provide 1,000-year protection:

1. A thickness of 100 grain layers (minimum) over a cross section.

2. Achieving and maintaining a fine, equiaxed grain structure. 
3. No deformation in a critical range of $0.1-5 \%$.

4. Control of the temperature below the recrystallizing point of lead.

All of these appear to be practically unachievable for the Yucca Mountain waste package. For instances, if lead were cast in the spent fuel container, grains would be large $(1-20 \mathrm{~cm}$ in the Canadian experience); the temperature at the Yucca Mountain site $\left(200^{\circ} \mathrm{C}\right.$ for several decades) would cause grain growth in initially fine-grained materials, and recrystallization temperatures for lead are quite low (even below $0^{\circ} \mathrm{C}$ for $10 \%$ or larger strains). Even if grain refiners were used (e.g. copper) in time these could segregate (Krysko, 1976; Reinert, 1971).

\section{LEAD IN THE SWISS PROGRAM}

The current Swiss design calls for a very thick-walled steel container into which high-level waste is to be sealed (NAGRA, 1984; Grauer, 1986). Before making this decision ti.e Swiss analyzed various materials, including lead (Grauer, 1984). The salient points of the review that lead received are summarized below.

It was recognized that lead would not be an acceptable material by itself because of its poor strength and that its attractiveness would reside in its gamma-shielding and general corrosion properties.

Examining particular aspects of lead corrosion, the author of the review indicates that archeological finds show that the metal holds up well in time even in oxygenated water. Badly corroded lead from a Punic ship was attributed to sulfide attack. Specimens are attacked at the grain boundaries and grain size is very important for long-term performance.

The review of general corrosion found that above $\mathrm{pH} 6$ lead has a small domain of thermodynamic stability so that it will not corrode significantly under strongly reducing conditions. The Eh-pH diagrams, however, should be re-drawn with more recent data. Outside the immunity domain corrosion is strongly delayed by the evolution of hydrogen (in a closed environment). In natural waters the corrosion products build protective layers so that corrosion proceeds at a rate of less than $10 \mathrm{um} / \mathrm{yr}$. Low-ionic strength waters with high levels of carbonic acids, however, are aggressive. An even stronger attack is given by sulfides, possibly because the lead sulfide layer is a good conductor. Corrosion is also rapid in soils containing organic acids. Corrosion is small in sulfate-rich media because of a protective layer of lead-sulfate. Protective layers are important for lead performance and high corrosion rates in the laboratory are often contradicted by low corrosion rates in natural systems.

The review of localized corrosion found that intercrystalline corrosion is important, especially with large grain size, but can be delayed by cathodic reactions. If lead were to be chosen, one should give a close look to intercrystalline corrosion in buried cables. Crevice corrosion is 
certainly a problem in unbuffered chloride solutions; in natural water the danger should be reduced because of possible buildup of a carbonate layer.

In a review of galvanic corrosion, it is the reviewer's opinion that, "Because, in galvanic corrosion, several effects are very complex in real systems, and because the polarity of corrosion cells can change with time or with a variation in temperature, it would be advantageous to avoid using combinations of metals as much as possible." The report goes on to say that: "The question of contact corrosion is especially important with titanium. In the titianium/lead cell, titanium is the cathode and lead is preferentially attacked. In closed systems corrosion is determined by the rate of arrival of the oxidizing species." "In the Swedish concept of the titanium/lead container, it is understood that the titanium will crack after a relatively short time and that lead takes on the corrosion barrier function. In the vicinity of the crack one must expect an accelerated rate of corrosion. There exist concerns about crevice corrosion of lead. All these uncertainties - and especially the question of the hydrogen effect (on titanium, translators note) - would require a large research and development effort, and it is questionable whether this would help reach a high certainty of prediction."

In summary, lead is not implemented in the Swiss design because of the preference for a single component material in order to avoid galvanic corrosion and because of lead's tendency to corrode intergranularly.

\section{LEAD IN THE BRITISH PROGRAM}

Lead has received consideration in the British waste-disposal program in the past, and a number of British papers regarding its potential use and properties have been published. At present, the British do not appear to have a strong interest in the use of lead for geologic disposal.

Lead was initially taken into consideration as a secondary corrosion barrier for HLW packages to be disposed of in a seawater environment and isolated for periods of around 1,000 years. The review of the archeological record in seawater (Tylecote, 1977) expressed uncertainty regarding the potential of intergranular penetration: "Slow cooled lead can have a very large grain size as has been shown by myself (Tylecote, 1962) and Professor Krysko (1976), and it would be possible for penetrations to go a long way normal to the surface if the grain directions were favorable, which they of ten are." The "general impression," however, was that lead could be sufficiently resistant for the above purpose provided it were used in great enough thickness. The report also pointed out that, on the whole, ancient lead was of "reasonable purity" and that sulfide from sulfate reducing bacteria is deleterious to lead corrosion resistance. A later report examining the known behavior of lead as a corrosion resistant medium in underseas and in soils (Tylecote, 1983) confirms the importance of fine grain size and the role of certain impurities in obtaining long-term corrosion protection. The archeological evidence would also confirm that, in a galvanic couple with copper, the exposed lead would become the anode and the rate of corrosion would be accelerated in localized areas. 
In 1983, a report largely devoted to steel presented work done also with lead and other metals (Marsh, 1983). In the experiments reported, lead was exposed to "brine" that was obtained by evaporating synthetic granite groundwater to saturation. Temperatures were $50^{\circ} \mathrm{C}$ and $90^{\circ} \mathrm{C}$ and the test duration was 1000 hours. When oxygen was present at $90^{\circ} \mathrm{C}$ the general corrosion rate was 17 microns/year and some pitting was observed. At $50^{\circ} \mathrm{C}$, the rate was 15 microns/year and no pitting was observed.

One last paper dealing with lead in HLW packages presents a finiteelement structural analysis of a thin-walled titanium container incorporating lead cast around a canister of vitrified waste (Cripps, 1985). The lead is modeled as filling all void space. Under pressure loading (19 $\mathrm{MPa}$ ) the behavior of the package is dominated by the stiffness of the contents. In particular, because of the small thickness of titanium and the low stiffness of lead, "...the relatively high stiffness of the glass attracts a significant proportion of the loading." "For temperature loading, the relatively large differences in coefficient of thermal expansion between lead and the other materials cause high tensile stresses in the titanium container." "The peak stresses due to a temperature rise of $75^{\circ} \mathrm{C}$ were calculated to be about $240 \mathrm{~N} / \mathrm{mm}^{2}\left(2400 \mathrm{~kg} / \mathrm{cm}^{2}\right)$ although it should be noted that the backfill was not modeled in the thermal analysis." The fact wat the coefficient of expansion of lead is about three times greater than for steel and titanium "...could prove an important factor in designing containers using lead as filler material." The paper also indicates that although the placement temperature for lead would not adversely affect the high level waste glass, "...the problems of filling container voids at this temperature in a highly shielded work cell should not be underestimated." 
Barkatt, A., and others, 1984. "Effects of Metals and Metal Oxides on the Leaching of Nuclear Waste Glasses," in Scientific Basis for Nuclear Waste Management, Vo1. 26, pp. 689-696.

Buckwalter, C. Q., and L. R. Pederson, 1982. "Inhibition of Nuclear Waste Glass Leaching by Chemisorption," Journal of the American Ceramic Society, Vo1. 65, No. 9 .

Cohen, J. J., D. G. Coles, and L. D. Ramspott, 1981. "Lead Encapsulation of Nuclear Waste: A Risk Assessment," Transportation of the American Nuclear Society, Vol. 34, p. 350 .

Cripps, J. E., 1985. "The Design of Nuclear Waste Containers and Irradiated Fuel Transport Flasks," in Lead: Its Role in Nuclear Waste Management, proceedings of a seminar organized by the Lead Development Association and held at the Palais des Congress, Brussels, Belgium, November 1984.

De Micheli, S. M., et al., 1986. Uso de1 plomo en contendeores de residuos radioactivos de alta actividad, IAEA-SM-289/22, International Atomic Energy Agency, Vienna, Austria, p. 449.

De Regge, P., J. Broothaerts, and F. Casteels, 1985. "Encapsulation of Cladding Waste by Lead Alloys," in Lead: Its Role in Nuclear Waste Management, proceedings of a seminar cïganized by the Lead Developricat Association and held at the Palais des Congress, Brussels, Belgium, November 1984 .

De Regge, P., 1986. Conditioning of Cladding Waste for Long-term Storage by Press Compaction and Encapsulation in Lead Containment - Final Report, EUR-10824-EN, Commission of the European Communities, Luxembourg.

Ekbom, L. B., K. Hannerz, and K. S. Henrikson, 1980. "Corrosion Studies on Copper and Titanium-Lead Canisters for Nuclear Waste Disposal," in Underground Disposal of Radioactive Waste, Vol. 1, International Atomic Energy Agency, Vienna, Austria.

FEMA (Federal Emergency Management Agency), 1988. Stockpile Report to the Congress, April-September 1987, FEMA-36 Washington, D.C.

Fish, R. L., N. Wynhoff, and V. J. Ferrell, 1982. Spent LWR-Fuel WastePackage-Stabilizer Recommendations, HEDL-7204, Hanford Engineering Development Laboratory, Richland, Wash.

Grauer, R., 1984. Behaeltermaterialien fuer die Endlagerung hochradioaktiver Abfaelle: Korrosionschemische Aspekte, EIR Bericht 523, Swiss Federa1 Institute for Reactor Research, Wuerenlingen, Switzerland. 
Grauer, R., 1986. Bentonit als Verfuellmaterial im Endlager fuer hochaktiven Abfal1: Chemische Aspekte, EIR Bericht 576, Swiss Federal Institute for Reactor Research, wuerenlingen, Switzerłand.

Guenther, R. J., 1984a. Potential Uses of Lead in Nuclear Waste Disposal, LM-337-1, Pacific Northwest Laboratory, Richland, Wash.

Guenther, R. J., 1984b. Potential Uses of Lead in Nuclear Waste Disposal, LM-337-2, Pacific Northwest Laboratory, Richland, Wash.

Guenther, R. J., 1985a. Potential Uses of Lead in Nuclear Waste Disposal, LM-337-3, Pacific Northwest Laboratory, Richland, Wash..

Guenther, R. J., 1985b. Potential Uses of Lead in Nuclear Waste Disposal, LM-337-4, Pacific Northwest Laboratory, Richland, Wash.

Guenther, R. J., 1986. Potential Uses of Lead in Nuclear Waste Disposal, LM-337-5, Pacific Northwest Laboratory, Richland, Wash.

Gurwe11, W. E., 1981. A Survey of Matrix for Solidified Radioactive HighLevel Waste, PNL-3512/UC-70, Pacific Northwest Laboratory, Richland, Wash.

Hancox, W. T., 1986. "Progress in the Canadian Fuel Waste Management Program," in Proceedings of the Second International Conference on Radioactive Waste Management, Canadian Nuclear Society, Winnipeg, Manitoba, September 1986 .

Hebe1, W., and G. Cittoñe, Eds., 1982. Conditioning and Storage oí Spent Fuel Element Hulls, Harwood Academic Publishers.

Hebe1, W., A. Cricchio, and B. Haijtink, 1985. "Status of Nuclear Waste Management in the European Community: Common R\&D Efforts and the Potential Role of Lead," in Lead: Its Role in Nuclear Waste Management, proceedings of a seminar organized by the Lead Development Association, Brussels, Belgium, November 1984.

Johnson, L. H., et al., 1987. "Engineered Barrier Research for the Canadian Nuolear Fuel Waste Management Program," in Radioactive Waste Management and the Nuclear Fuel Cycle, Vol. 8, Nos. 2-3. pp. 105-143.

Krysko, W. W., and R. Lehrheuer, 1976. "Metallurgical Investigation of Roman Lead Pipe From Pompeii," Journal of the Historical Metallurgical Society, Vol. 10, No. 2, pp. 53-63.

Krysko, W. W., 1980. "Blei als Behaelterwerkstoff fuer Atommuell - Analyze des Korrosionsverhaltens aufgrund archaeologischer Funde," Metall, Vo1. 34, pp. 433-436.

Krysko, W. W., 1983. "Absolute und relative Korngroesse," Meta11, Vol. 37, pp. 224-1229. 
Krysko, W. W., 1985. "Archeological Evidence of the Effect of Grain Size and Shape on the Very Long Term Durability of Lead," in Lead: Its Role in Nuclear Waste Management, proceedings of a seminar organized by the Lead Development Association in Brussels, Belgium, November 1984.

Lehman, R. L., and F. A. Kuchinski, 1985. "The Effect of Varions Lead Species on the Leaching Behavior of Borosilicate waste Glasses," in Lead: Its Role in Nuclear haste Management, proceedings of a seminar organized by the Lead Development Association in Brussels, Belgium, November 1984.

Lutze, W., 1987. "Nuclear Waste Management in Europe," Materials Research Society Bulletin, January 1/February 15, p. 29.

Lynn, J. C., W. R. Warke, and P. Gordon, 1975. "Solid Metal-Induced Embrittlement of Steel," Materials Science and Engineering, Vol. 18, pp. 51-62.

Marsh, G. P., et al., 1983. "Corrosion Assessment of Metal Overpacks for Radioactive Waste Disposal," European Applied Research Reports - Nuclear Science and Technology, Vol. 5, No. 2, pp. 223-252.

Mathew, P. M., et al., 1985. Heat Iransfer Coefficients for Lead Matrixing in Disposal Containers for Used Reactor Fuel, AECL-8365, Atomic Energy of Canada Limited, Pinawa, Manitoba.

Mathew, P. M., 1986a. "Investigation on Metal Matrices for Nuclear Fuel Waste Disposal," in Proceedings of the Second International Conference on Radioactive Waste Management, Canadian Nuclear Society, Winnepeg, Manitoba, September 1986.

Mathew, P. M., igo6t. Casting Properties of Metal Matrices for Nuclear Fuel waste Disposal: Review and Assessment, AECI-TR-371, Atomic Energy of Canada Limited, Pinawa, Manitoba.

Mathew, P. M., and P. A. Krueger, 1987. The Corrosion Performance of Lead and Zinc in Nuclear Waste Packages: Canada and United Kingdom, 1986 Annual Report for Project IM-349, Whiteshell Nuclear Research Establ ishment, Pinawa, Manitoba.

Mattsson, E., 1978. "Corrosion Resistance of Canisters for Final Disposal of Spent Fuel," in Scientific Basis for Nuclear Waste Management, G. McCarty, Ed., Vol. 1, p. 271.

McKay, P., D. W. Shoesmith, and M. G. Bailey, 1985. "Mechanisms of Metal and Metal Oxide Corrosion," in Environmental Research and Underlying Chemistry Research, Proceedings of the Fifth Information Meeting of the Nuclear Fuel Waste Program, AECL-TR-216, Atomic Energy of Canada Limited, Pinawa, Manitoba.

Merz, M. D., 1982. State-of-the-Art Report on Corrosion Data Pertaining to Metallic Barriers for Nuclear Waste Repositories, PNL-4474/UC-70, Pacific Northwest Laboratory, Richmond, Wash. 
Montin, J. L., et al., 1987. The Detection of Gauging of Voids in Lead Castings with $14 \mathrm{MeV}$ Neutron," AECL-TR-423, Atomic Energy of Canada Limited, Pinawa, Manitoba.

(NAE/NAS) (National Academy of Engineering/National Academy of Sciences), 1979. Solidification of High Level Radioactive Waste, NUREG/CR-0895, L.S. Nuclear Regulatory Commission, Washington, D.C.

STEAG Kernenergie GmbH, 1984. Konzept der Anlage zum Uimladen der HAA-Kokillen in Endlagerbehealter, NAGRA NTB 84-23, NAGRA, Baden/Switzerland.

NBS (National Bureau of Standards) 1987. Evaluation and Compilation of DOE Waste Package Test Data -- Biannual Report: December 1985-July 1986, Vol. 1, prepared for the U.S. Nuclear Regulatory Commission, NiREG/CR-4735, Washington, D.C.

Nordesjo, E., 1978. Safety Analysis of the Encapsulation of Irradiated Fuel Elements in Copper Containers, ASEA-ATOM 1978-03-20, KBS-TR-112, Stockholm, Sweden.

Nuttall, K., et al., 1983. "The Canadian Container Development Program for Fuel Isolation," in The Scientific Basis of Nuclear waste Management, Vol. $15, \mathrm{p} .77$.

Paiacios, E., et al., 1983. Bases conceptuales para la construccion de un repositoric en la Argentina, IAEA-CN-43/439, International Atomic Energy Agency, Vienna, Austria, p. 179.

Pitman, S. G., et al., 1987. Potential Uses of Lead in Nuclear Waste Disposal, Report for Project LM-337 for periud from July 1986 through May 1987, Battelle Pacific Northwest Laboratories, Richland, Wash.

Schneider, K. J., and D. J. Bradley, 1988. "Brief Survey of the Uses of Metallic Lead in Waste Packages in Other Countries," presented at the initial meeting of the DOE Peer Review Panel on Lead, November 12, 1988.

SCK/CEN, 1986a. MOL-Research Division Report, July, 1-December, 31, 1985, Chapter 4, P. 73 .

SCK/CEN, 1986b. MOL-Research Division Report, July, 1-December, 31, 1985, Chapter 4, P. 65 .

SCK/CEN, 1987. MOL-Research Division Report, January 1-June, 30, 1987, Chapter 4, p. 72 .

SKBF, 1978. Lead-Iined Titanium Canisters for Reprocessed and Vitrified Nuclear Fuel Waste--Evaluation of the Corrosion Aspects, the Swedish Corrosion Institute, in KBS Technical Report 107, Stockholm, Sweden.

SKBF, 1983. Final Storage of Spent Nuclear Fuel -- KBS-3, Vols. I, II, and III, Swedish Nuclear Fuel Supply Company, Division KBS, Stockholm, Sweden. 
Statens Kaernkraftinspektion, 1984. Review of Final Storage of Spent Nuclear Fuel -- KBS-3, Swedish Nuclear Power Inspectorate, Technical Report

Stockholm, Sweden. SKi 84:j.

Tylecote, R. F., 1977. "Durable Materials for Seawater: The Archeological Evidence," International Journal of Nautical Archeology and Underwater Exploration, Vol. 6, pp. 269-283.

Tylecote, R. F., 1983. "The Behavior of Lead as a Corrosion Resistant Medium Undersea and in Soils," Journal of Archeological Science, Vol. 10, pp. 397-409.

Werme, L., I. L. Hench, and A. Lodding, 1982. "Effect of Overpack Materials on Glass Leaching in Geological Burial," in Scientific Basis for Nuclear Waste Management, Vol. 5, W. Lutze, Ed., pp. 135-144.

Werme, L. O., and A. Bergstrom, 1985. "Lead Quality Criteria and Containment Technology for the Disposal of High Level Nuclear Waste," in Lead: Its Role in Nuclear Waste Management, proceedings of a seminar organized by the Lead Development Association and held in Brussels, Belgium, November 1984.

Woodbury, W. D., and J. A. Rathien, 1983. Lead: Mineral Commodity Profiles, U.S. Bureau of Mines, Department of the Interior, Washington, D.C.

Woodbury, w. D., 1985. "Lead," in Mineral Facts and Problems, Bulletin 675, L.S. Bureau of Mines, Department of the Interior, Washington, D.C.

Zausnica, A., 1985. in Lead: Its Role in Nuclear Waste Management, Proceedings of a seminar organized by the Lead Development Association and held in Brusseis, Belgium, November 1984. 
Appendix B

IEAD AS A CORROSION BARRIER

INTRODUCTION

Soon after the permanent closure of the repository, the environment surrounding the waste packages in the tuff repository will heat up and the ambient environment will become one of steam plus air. The repository pressure remains constant at one atmosphere in tuff since the porous rock is reported to prevent any pressure increase and to permit replenishment of air (DOE, 1988).

Drawing both from the nuclear and nonnuclear literature on lead corrosion, this appendix provides a further analysis of the expected corrosion performance of lead in the proposed repository environment. Also examined are the effects that lead may have on the corrosion performance of other contacting materials.

\section{IEAD CORROSION DLRING THE STEAM/AIR PHASE}

In the current waste-package design concept for the tuff repository, the container surface is expected to remain above $95-98^{\circ} \mathrm{C}$, the boiling temperature of the ground water, for at least 300 years after repository closure. As shown in Figure $B-1$, it is projected that the peak container surface temperature of $a$ bnint $245^{\circ} \mathrm{C}$ will be reached in about 20 years, after which it is expected to decrease continuously to about $150^{\circ} \mathrm{C}$ at about the 300 -year stage. The temperature of the outer skin of the container should still be above $100^{\circ}$ 1,000 years after emplacement for a large number of waste packages. Oxidation in humid air for this temperature profile could, therefore, be a major form of corrosive attack under tuff repository conditions.

Corrosion rates of lead in steam have been reported by the U.S. National Association of Corrosion Engineers (NACE, 1979). The data show a variable corrosion rate between 0.5 and $1.27 \mathrm{~mm} / \mathrm{yr}$ at all temperatures between 25 and $150^{\circ} \mathrm{C}$ and acceleration of the rates above the latter temperature. These data have been questioned because a personal communication with $N$. Hammer of NACE revealed that it is impossible to cite the origin of the data. Additional information on steam corrosion (Rabald, 1968) reports that the rate is less than $0.08 \mathrm{~mm} / \mathrm{yr}$ (no lower 1 imit is given) up to $150^{\circ} \mathrm{C}$ in steam with accelerated rates at higher temperatures. Recent measurements by Westerman indicate much lower uniform corrosion rates: $<0.004 \mathrm{~mm} / \mathrm{yr}$ for several lead alloys in humidified air at $150^{\circ} \mathrm{C}$ (Westerman, 1988). We could not resolve the conflict in the data as we do not have the details of the earlier tests. Should lead be used in a manner in which it would be exposed to a humid environment, further work would be needed, including studies of the effects of irradiation and grain size on corrosion. 


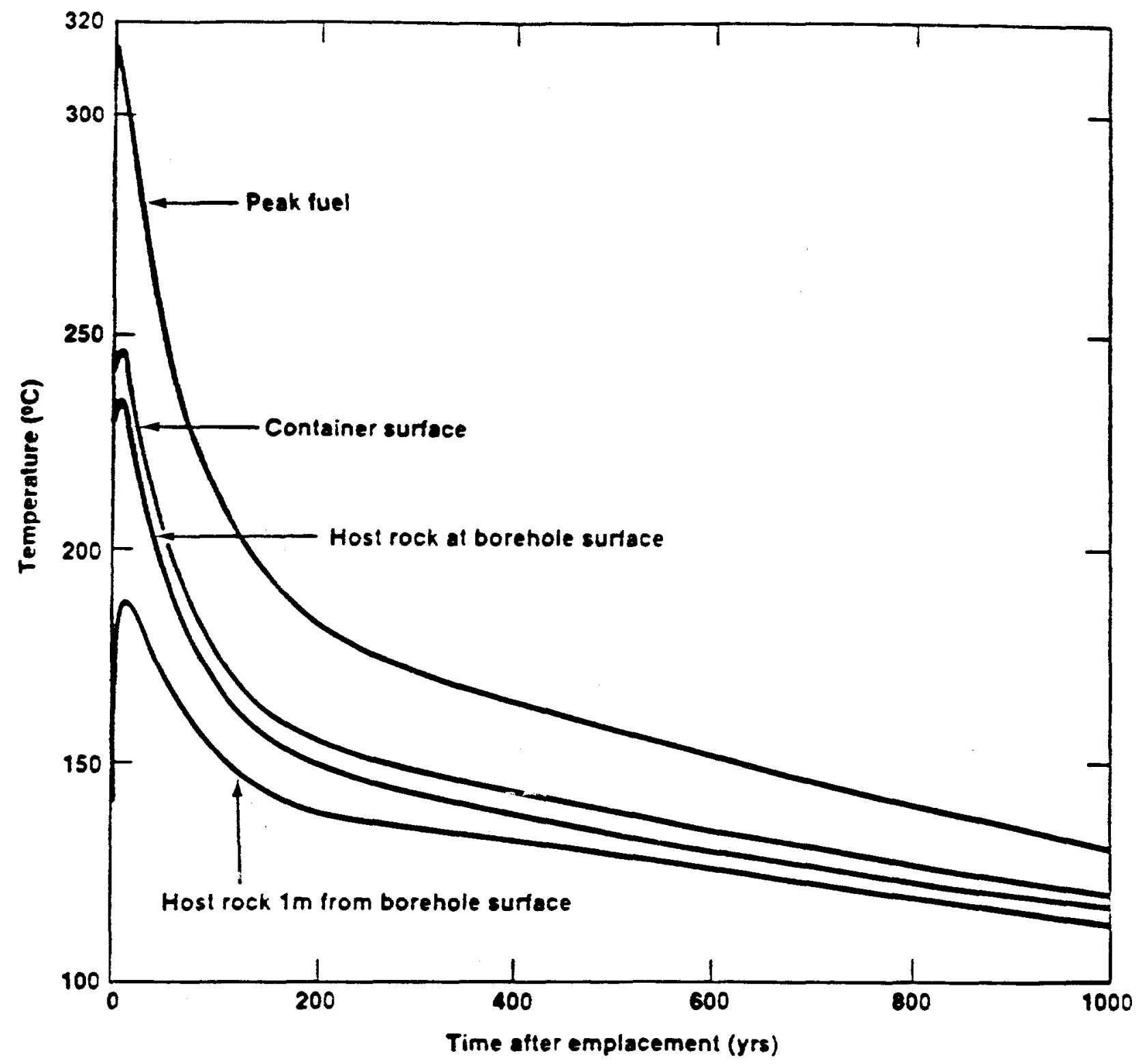

Waste form - Spent fuel (pressurized water reactor)
Local power density - $57.0 \mathrm{~kW} /$ acre
Aerial power density $-48.4 \mathrm{~kW} /$ acre
Average package power at burial $-3.3 \mathrm{~kW}$
(10 yrs out of reactor)
Containet diameter $-0.7 \mathrm{~m}$
Distance between containers $-5 \mathrm{~m}$
Distance between drtts $-47 \mathrm{~m}$

Figure B-1. Example of temperature histories of waste package components and host rock for vertically emplaced spent fuel containers $10^{\prime}$ Neal et al..1984) 
Table B-1. Average corrosion rate of lead in steam ${ }^{a}$

\begin{tabular}{|c|c|}
\hline $\begin{array}{l}\text { Temperature } \\
\left({ }^{\circ} \mathrm{C}\right)\end{array}$ & $\begin{array}{l}\text { Rate } \\
(\pi m / y r)\end{array}$ \\
\hline $\begin{array}{l}25 \\
50 \\
75 \\
100 \\
125 \\
150 \\
300\end{array}$ & $\begin{array}{l}0.5-1.27 \\
0.5-1.27 \\
0.5-1.27 \\
0.5-1.27 \\
0.5-1.27 \\
0.5-1.27 \\
\text { Higher than } 1.27\end{array}$ \\
\hline
\end{tabular}

\section{AQUEOLS CORROSION OF LEAD}

The reported corrosion rates of lead and its alloys in $\mathrm{J}-13$ well water at approximately 90 to $95^{\circ} \mathrm{C}$ range from 8.8 to $31.3 \mathrm{micron} / \mathrm{year}$, averaged over the period of twelve-month tests (Pitman, 1987). In these tests, the rate of at tack appears to gradually decrease with time except for "corroding" lead which showed ar: increasing rate after an early decline. This observation may in part, be related to the low sulfate content of the J-13 well water, which may be too low to provide an effective barrier layer of lead sulfate. Thus, while it is believed that oxidation will be the major corrosion mode as discussed above, there is evidence of relatively high corrosion rates in the liquid-water stage after the temperature in the proposed tuff repository drops below the boiling point. Although these rates are somewhat high, a $1.25-\mathrm{cm}-\mathrm{thick}$ layer of lead would provide corrosion protection for about 350 to 1560 years based on the above results.

Furthermore, the possibility of intergranular corrosion during wet periods in the tuff environment also needs to be considered.

\section{INTERGRANULAR CORROSION}

An appreciable time is expected to pass before water can contact the lead, which is therefore likely to develop a different grain structure than when it was originally put in place. A shift towards larger grains is to be expected as a result of the long time at elevated temperature (Gmelin, 1972; 
Lead, 1984). This is known to decrease corrosion resistance and favor intergranular at tack.

When lead and its alloys corrode via preferential attack on grain boundaries, grain size and shape play a decisive role in its corrosion resistance. This is a general finding in diverse conditions such as aerated and nonaerated soil corrosion over both the medium-and long-term, galvanic corrosion in both acidic and non-acidic solutions, corrosion in organic acids and in high temperature applications in the chemical industry. The literature emphasized the importance of maintaining small grain size in order to obtain the best corrosion resistance.

A review of the literature on archaeological artifacts, which was made for waste isolation purposes, (Krysko, 1976, 1980, 1983, 1985; Tylecote, 1977, 1983 ) indicates that lead objects can survive for thousands of years under a variety of conditions up to $48^{\circ} \mathrm{C}$. General corrosion is evidently slow, but the observations (of Krysko, especially) show that in the medium ( 150 years) and in the long term (several centuries) corrosion can be dominated by grain boundary attack. Resistance to general corrosion was found to be provided by a hard inner layer of $\mathrm{PbO}$, usually covered by a second layer consisting of $\mathrm{Pb}$-carbonate. Cracks in the protective layers occur, probably as a result of differences in density and thermal expansion between the products and the metal. When it occurs, intergranular attack appears to start at breaks where large grains were available underneath. The exact mechanism for the intergranular attack in Lead and why it stays confined to the grain boundaries after initiation is not established. In the case of other metals, for example stainless steels, metallurgical inhomogeneities have been found to contribute. Impurities may also be implicated. Regardless of the mechanism of intercrystalline attack, it has been shown that damage can occur with little weight loss. Because of this, intercrystalline attack cannot be excluded i.s any given situation and a metallographic analysis should be performed to detect its presence. See also the discussion on "Lead in the German Design" in Appendix A.

\section{PITTING ATTACK IN SOIL TESTS}

Pitting and general corrosion were examined in four different sets of long-term experiments with lead buried in various soils for a number of years (Gilbert, 1951; 1946; Romanoff, 1957). Low-oxygen conditions were said to be most conducive to localized attack, although analyses for oxygen were not given. Gilbert's results showed that pits continued to propagate after 10 and more years, and some reached penetration of several millimeters. If the general corrosion and pitting rates are assumed to be 1 inear, the 1000-year thickness loss would be about 0.75 inch and pitting penetration about 12 inches. Another observation made by Gilbert is the tendency for pits to follow grain boundaries.

Similar results were reported by Romanoff, who also noted that pitting depth decreased with the aeration of the soil and with increased sulfate content. Corrosion weight loss showed the same trends. In considering 
whether extrapolations can be made from the data, it appears that practically all the cases that seem most relevant to the Nevada site show linear rates over periods of up to 17 years. Also, the pitting of lead seen in these soil corrosion tests occurred under relatively mild exposures, that is, where the soil water analyses do not suggest any particular aggressiveness beyond the water that represents the Yucca Mountain repository horizon.

\section{SIRESS CORROSION}

Transgranular cracking in high nickel alloys ( $70 \% \mathrm{Ni}$ ) has been observed in a high-temperature water environment when $\mathrm{Pb}$ is present even when there is no metallic contact initially, as demonstrated in tests in the vicinity of $300^{\circ} \mathrm{C}$ (Copson 1965; 1968; 1974; Airey, 1976). In the nuclear industry many of the construction sites and manufacturing shops have disallowed the use of lead-containing lubricants, lead tools (hammers) and sometimes even leaded gasoline. Although the exact mechanism remains to be established, a nickel-based disposal container with a lead component may be susceptible to cracking in a similar way. A better understanding would be required of the time-temperature-stress relationship of lead-enhanced stress corrosion of nickel-based alloys if these are to be used. It is important to note that Alloy 825 contains a much lower nickel content (about $42 \%$ ) than the above discussed alloys and recent work found no evidence of cracking for l-bend specimens of Alloy 825 either in an air-steam mixture at $100^{\circ} \mathrm{C}$ (and in contact with metallic lead) or in air-saturated concentrated Iuff groundwa: $\epsilon$ : containing lead ions after a 6-month exposire (Westerman et al, 1988).

Another issue of potentialiy serious concern is related to possible lead contamination of the container closure fusion weld zone for nickel-based alloys. It is known that traces of lead located in the heat affected zone of such welds in Incoloy 825 can lead to stress corrosion cracking. It is also known that trace amounts of lead $(<0.01 \%)$ incorporated into the weld fusion zone itself will cause severe hot cracking during weld solidification in this alloy (Lingenfelter, 1989). This may be a difficult problem to prevent because of the high vapor pressure of lead near the welding temperature; nor will it be possible to inspect the inner surface of the weld zone to determine if cracking has occurred. It would appear that lead can be used only if the container can be designed so that the possibility of lead contamination of the weld zone is eliminated.

\section{GAIVANIC CORROSION}

Galvanic corrosion could occur when two metals are used in the container construction, and the outer wall is breached. More noble metals such as copper would generally be protected at the expense of $\mathrm{Pb}$ when coupled, but the opposite would apply if carbon steel, for instance, was substituted for Cu. It is also important to take into account the observation that the polarity of the $\mathrm{Pb} / \mathrm{Fe}$ couple can reverse at certain temperatures or when in alkaline environments (De Micheli, 1.986). Quantitative data would be needed to aid in the design of containers in which galvanic couples are exposed to a specific corrosive environment. 
Under practical circumstances, the galvanic behavior of $\mathrm{Pb}$ depends to a large extent on the $f i l m(s)$ that may be present on the lead surface (LaQue, 1963). For example, when coupled to $\mathrm{Pb}$, iron is preferentially corroded in acid solutions, but the current reverses in alkaline solutions when the films on the $\mathrm{Pb}$ become soluble. A $67 / 33 \mathrm{Ni} / \mathrm{Cu}$ alloy caused a large acceleration in the corrosion of $\mathrm{Pb}$ in tap water at $200^{\circ} \mathrm{C}$. In other solutions, where there are sufficient quantities of ions with insoluble $\mathrm{Pb}$ salts, the $\mathrm{Pb}$ remains protected in spite of coupling to $\mathrm{Cu}$ alloys.

Barrier films of ten build up on lead as insoluble corrosion products form, and it is well known that corrosion will drop off with time even when galvanic potentials exist. The formation of the passivating layers is very dependent on the nature of the electrolyte, and predictions of actual rates under waste repository conditions would need an understanding of mechanisms and environmental changes occurring over hundreds of years.

\section{HOT-METAL EMBRITTLEMENT}

This section sumarizes items taken from the literature with regard to possible embrittlement of other metals in contact with lead at elevated temperatures. It should be mentioned that most of the available reports have the limitation that only results of short-term tests are available. Data for longer exposure times would be needed if waste-package designs using lead in combination with other materials were to be considered.

When two metals are in intimate contact, the lower melting one of ten calies embrittlement in the other. When lead is the embrittling element, the mos: of $t \in n$ quoted lower transition temperature, in cases where embrittlement can be induced, is about 0.75 times the melting point (in degrees Kelvin).

The use of lead inside a waste package container could involve either the pouring of molten metal, or pre-cladding the container wall with lead. It is clear from the literature that embrittlement by the solid phase is much slower than by the liquid metal. Short-term tests simulating the casting of lead into containers, however, have shown no evidence of problems in the short times involved (Mathew, 1983; Fish, 1982). Therefore, the major concern that remains is for the long period where hot lead would contact the container wall within a harmful temperature range. Solid metal induced embrittlement (SMIE) is of concern in all cases where liquid metal induced embrittlement (LMIE) can occur. It has been reported that similar processes occur above and below the melting point (Lynn, 1974). In fact, with reference to metals that include lead, "results suggest that all metals which in the liquid state embrittle steel will (also) embrittle steel below their melting points," provided that the solid embrittler does not spall off. This "may well be found in many, if not all, other metal-metal systems that are subject to LMIE."

Carbon steels and low alloy steels, as well as copper alloys can be embrittled by hot, solid lead. When the alloy itself contains lead, as an impurity or addition, SMIE has been seen at $204^{\circ} \mathrm{C}$ in several steels and in bronze. When the lead was external, loss of ductility usually started at a higher temperature, i.e. $288^{\circ} \mathrm{C}$, although this temperature was as low as $160^{\circ} \mathrm{C}$ in one instance (a notched 4140 steel quenched and tempered to a high yield strength). It may be significant that the $160^{\circ} \mathrm{C}$ failure occurred as a delayed 
failure (under constant load conditions) as compared to standard tensile tests in the other cases mentioned. Delayed failure may be more applicable to the waste package conditions. It should be noted that the increased yield strength of the 4140 steel specimen probably contributed to loss of ductility and that non-hardened material will probably be used for the waste package.

When a barrier film is present, such as an oxide, LMIE or SMIE can be expected to be much more unlikely, and this may be the reason why apparent discrepancies exist in reported results, as evidenced by the embrittlement reported above versus for instance the absence of embrittlement in work done in Belgium (Hebel, 1982). Lead shielded shipping casks with stainless steel shells are in general use, and no problems with LMIE or SMIE are believed to exist (Wells, 1989).

LMIE has been reported both to occur and to be absent in additional materials, such as Type 304 stainless steel, and the test procedures employed are suspected to account for such differences. Embrittlement was also found in $13 \% \mathrm{Cr}$ steel. No adverse results for Zircaloy cladding have been found. Recent tests (Westerman, et. a1, 1988) showed no evidence of embrittlement in slow-strain-rate tests of Alloy 825 and 1020 steel in molten lead at $350^{\circ} \mathrm{C}$.

Test methods are usually accelerated, with the application of slow straining as one of the prominent techniques. Accelerated tests have often been used to indicate potential problems or to select alloys for specific uses.

Although some reports indicate that the impurities in lead are relatively unimportant in the embrittlement process it is clear (Hebel, 1982) that impurities such as $\mathrm{Ag}, \mathrm{Cd}, \mathrm{Zn}$ and $\mathrm{Cu}$ in $\mathrm{Pb}$ at $100^{\circ} \mathrm{C}$ have a vary unfavorable effect on the performance of Type 304 SS in contact with the hot, solid lead. In 9 - and 16-month exposuies, grain boundaries were attacked and some grains were dislodged. This was not seen in tests of short duration. When pure lead was substituted, the effect disappeared. We believe that this result also calls for longer term data for the specific purity of the lead candidate alloy in contact with metals that are proposed for specific container designs should such designs be contemplated. The mechanism of this type of attack appears to differ from embrittlement by lead itself.

The literature (Kamdar, 1984) also mentions the possibility of alloying additions that may alleviate embrittlement, but further research relevant to present waste package conditions is required.

We conclude from the literature examined that there is insufficient evidence now available to show that a hot lead internal component in contact with an outer wall of a waste container over a very long period of time either will or will not degrade the properties of the container material. Candidate waste package designs that contain lead would require extensive R\&D to ensure that they are problem-free with regard to long-term SMIE.

\section{CONCLUSIONS}

As can be seen from the preceding discussions, the available data are insufficient to fully assess the expected performance of lead as a corrosion barrier under the conditions expected at the Yucca Mountain site in Nevada, and a significant research-and-development effort would be needed should 
waste-package designs that use lead components as corrosion barriers be considered. When lead is used as a component in conjunction with other metals, a number of significant performance issues (e.g., galvanic corrosion and hot-metal embrittlement), which are not of significant concern in the present conceptual design, are introduced. In each of these cases as well, a significant research-and-development program would be necessary for any such design in order to assess and demonstrate compliance with the regulatory requirements. 
Airey, G. P., 1976. Corrosion, Vol. 35, P. 129.

Copson, H. R., and S. W. Dean, 196. "Effects of Contaminants on Resistance to Stress Corrosion Cracking of Ni-Cr Alloy 600 in Pressurized Water," Corrosion, Vol. 24, p. 55.

Copson, H. R., and G. Economy, 1968. "Effects of Some Environmental Conditions on Stress Corrosion Behavior of Ni-Cr-Fe Alloys in Pressurized Water," Corrosion, Vol. 24, p. 55.

Copson, H. R., D. van Rooyen, and A. R. McIlree, 1974. "Stress Corrosion Behavior of $\mathrm{Ni}-\mathrm{Cr}-\mathrm{Fe}$ Alloys in High Temperature Aqueous Solutions, "paper presented at the Fifth International Congress on Metallic Corrosion, Tokyo, Japan, 1972, National Association of Corrosion Engineers, Houston, Texas, pp. $376-79$.

De Micheli, S. M., et al., 1986. Uso del plomo en contenedores de residuos radioactivos de alta cctividad, IAEA-SM-289/22, International Atomic Energy Agency, Vienna, Austria, p. 449.

DOE (U.S. Department of Energy), 1988. Consultation Draft, Site Characterization Plan, Yucca Mountain Site, Nevada Research and Development Area, Nevada.

Fish, R. L., et al., 1982. Spent LWR Fuel Waste-Package-Stabilizer Recommendations, HEDL 7024, Hanford Engineering Development Laboratory, Richland, Wash.

Gilbert, P. T., 1946. "Corrosion of Copper, Lead, and Lead-Alloy Specimens after Burial in a Number of Soils for Periods up to 10 Years," J.I.M., Vol. 73 , p. 139.

Gilbert, P. T., and F. C. Porter, 1951. Report MG/BE/30/51 of the SubCommittee on the Corrosion of Buried Metals, Tests on the Corrosion of Buried Aluminum, Copper and Lead, BISRA.

Gmelins Handbuch, "Blei," Part Bl, Verlag Chemie GmbH, heinheim, Bergstrasse, Federal Republic of Germany.

Guenther, R. J., 1985. Potential Uses of Lead in Nuclear Waste Disposal, LM-337-4, Pacific Northwest Laboratory, Richland, Wash.

Guenther, R. J., 1986. Potential Uses of Lead in Nuclear Waste Disposal, LM-337-5, Pacific Northwest Laboratory, Richland, Wash. 
Hebel, W., and G. Cottone, Eds. 1982. Conditioning and Storage of Spent Fuel Element Hulls, Monograph V.9, Commission of European Communities, p. 157.

Holmes, J. F., 1963. "Lead and Lead Alloys. Corrosion Resistance - Part 1," Corrosion Technology.

Kamdar, M. H., Ed., 1984. Embrittlement by Liquid and Solid Metals, Metallurgical Society of AIME.

Krysko, W. W., and R. Lehrheuer, 1976. "Metallurgical Investigation of Roman Lead Pipe from Pompeii," Journal of the Historical Metallurgical Society, Vol. 10, No. 2, pp. 53-63..

Krysko, W. W., 1980. "Blei als Behael tewerkstoff fuer Atommuell -- Analyze des Korrosionsverhaltens aufgrund archaeologischer Funde," Metall, Vo1. 34, pp. 433-436.

Krysko, W. W., 1983. "Absolute und relative Kormgroesse," Metal1, Vol. 37, pp. 224-229.

Krysko, W. W., 1985. "Archeological Evidence of the Effect of Grain Size and Shape on the Very Long Term Durability of Ledd," in Lead: Its Role in Nuclear Waste Management, proceedings of a seminar organized by the Lead Development Association and held in Brussels, Belgium, November 1984.

Lead: Its Role in Nuclear Waste Management, proceedings of a seminar organized by the Lead Development Association and held in Brussels, Belgium, November 1984.

Lead Industries Association, Inc., no date. Lead for Corrosion Resistant Applications--A Guide, New York.

Lingenfelter, A., May 1989, Personal Communication, Lawrence Livermore National Laboratory, Livermore, California.

Mathews, P. M., et al., 1983. "Investment of Irradiated Reactor Fuel in a Metal Matrix," Canadian Metallurgical Quarterly, V. 22, No. 1, p. 107, 1982.

Mathew, P. M., and P. A. Krueger, 1987. The Corrosion Performance of Lead in Zinc in Nuclear Waste Packages: Canada and United Kingdom, 1986 Annual Report for Project LM-349, Whiteshell Nuclear Research Establishment, Pinawa, Manitoba.

Merz, M. D., 1982. State-of-the-Art Report on Corrosion Data Pertaining to Metallic Barriers for Nuclear Waste Repositories, PNL-4474/UC-70, Pacific Northwest Laboratory, Richland, Wash. 
(National Association of Corrosion Engineers), 1979. Corrosion Data Survey, 5 the edition, 2nd printing, compiled by N. E. Hammer, Houston, Texas.

0'Neal, W. C., et al., 1984. Preclosure Analys is of Conceptual Waste Package Designs for a Nuclear Waste Repository in Tuff, Lawrence Livermore National Laboratory, UCRL-53595, Livermore, Calif .

Pitman, S. G., et al., 1987. Potential Uses of Lead in Nuclear Waste Disposal, Report for Project IM-337 for Period from July 1985 Through May 1987, Battelle Pacific Northwest Laboratories, Richland, Wash.

Pryor, M. J., 1958. Corrosion, Vol. 14.

Reinert, M., 1971. "Entwicklungstendenzen in der Anwendung und Weiterverarbeitung von Blei," Erzmetall, Vol. 24, pp. 316-416.

Rabald, E., 1968. Corrosion Guide, 2nd revised edition, Elsevier Publishing Co., New York.

Schweitzer, D. G., 1987. Long-Term Containment of High-Level Waste: Equilibrium Reactions of $\mathrm{Cu}$ and $\mathrm{Pb}$ in Salt and Basalt Environments, draft, BNL-52089, Brookhaven, N.Y.

Shreir, L. L., 1976. Corrosion, Newnes-Butterworths, London and Boston.

Swandby, R. K., and S. W. Turner, 1963, in F. L., LaQue, and H. R. Copson, Ed., Corrosion Resistance of Metals and Alloys, 2nd edition, American Chemical scciety Monograph Series, Reinhold Publishing Corp., New York.

Wel1s, A. H., May 1989, Personal Communication, Nuclear Assurance Corporation, Norcross, Georgia.

Westerman, R. E., et. al., 1988. Potential Uses of Lead in Nuclear Waste Disposal, LM-337-7, Pacific Northwest Laboratory, Richland, Wash. 
Appendix C

LEAD AS A RADIATION BARRIER

\section{INTRODUCTION}

One potential function of lead in a waste package is to serve as a radiation barrier to attenuate the gamma dose rate to the surrounding environment. This may be desirable to limit exposure to personnel, to facilitate handling of the waste package, and to ensure better container corrosion performance in any given environment because of reduced radiolysis. The Yucca Mountain project believes that the shielding function, for reducing the exposure of repository personnel to radiation, can be better accomplished by providing shielding on the onsite transport and emplacement vehicles and this provides no incentive for incorporating lead in the design for radiation shielding. However, the effect of radiation on corrosion remains an area of some uncertainty, and lead would be very effective in reducing the concern in this area should such a function be required as a result of site characterization studies. It should also be noted that there are materials other than lead which are very effective radiation shields.

To provide an order-of-magnitude understanding of the potential advantage using lead as a shielding material, this chapter examines designs using lead and compares them to the case of a container without lead. To examine the advantage of using lead as a shielding material for a thin walled container (the reference design for tuff), the thickness of the container in the reference design was assumed to be $1 \mathrm{~cm}$ and the inside radius $30 \mathrm{~cm}$. The design is based on consolidated spent fuel.

\section{CALCULATIONAL PROCEDURE}

The following sections describe the calculational methods used, the input data, and the results of the analyses.

\section{Computer code}

The computer code ISOSHLD was used to conduct the analyses (Engel, 1966).

ISOSHLD is a point-kernel integration code that uses Taylor buildup factors to compute the dose rates. All data were taken from standard ISOSHLD libraries with the necessary exception of the input data. The source and shields were successively subdivided until the resulting dose rate changed by less than $10 \%$.

\section{Input data}

The cylindrical shape of the waste container makes it amenable to a standard geometry of fered by the ISOSHLD package (i.e., a cylindrical source surrounded by cylindrical shields). The source had an effective length of 385 $\mathrm{cm}$, and the dose rate was always determined for located at the midplane on the outside of the package. 
Reference materials for this analysis are standard materials in the ISOSHLD library. However, the complicated geometry of the consolidated fuel region cannot be handled explicitly. Therefore, the materials in the source region were homogenized and the gamma source was "smeared" out throughout this region. The homogenized densities of uranium, zirconium, oxygen, and lead (for the appropriate cases) that were used are given in Table C-1 along with the density of iron used for the container. Theoretical densities were taken from Chilton (Chilton 1964). The density of irradiated uranium dioxide was assumed to be $95 \%$ of the theoretical density.

Table C-1. Homogenized densities for consolidated spent fuel

$\begin{array}{ccc} & \text { Density } & \text { Homogenized } \\ & \text { (Theoretical) } & \text { Density } \\ \text { Material } & g / c c & \mathrm{~g} / \mathrm{cc}\end{array}$

$\begin{array}{lcc}\mathrm{U} & 10.96\left(\mathrm{UO}_{2}\right) & 5.00 \\ \mathrm{O} & 10.96\left(\mathrm{UO}_{2}\right) & 0.67 \\ \mathrm{Zr} & 6.6 & 1.09 \\ \mathrm{~Pb} & 11.34 & 3.02 \\ \mathrm{Fe} & 7.6 & --\end{array}$

Gamma-spectrum source terms were obtained from ORIGEN II computer calculations for 10-year old PWR fuel with a burnup of 33,000 megawatt-days per metric ton of heavy metal (Jansen, 1987). ORIGEN II gives the source terms on a per metric ton of heavy metal basis; therefore, the source terms have been multiplied by 4.61 , the number of metric tons of heavy metal proposed for the reference design under consideration (i.e., six PWR assemblies). No further processing of the source terms was necessary for them to be used in the ISOSHLD calculation.

\section{RESULTS FOR THIN-WALLED CONTAINERS}

Table C-2 gives the maximum gamma dose rate for three cases: the thinwalled container design without lead (Case 1), with lead filling the small annular void space (Case 2), and with lead filling all the void space (Case 3). 
Table C-2.. Dose rates for various thin-walled waste-package configurations

\begin{tabular}{|c|c|c|c|}
\hline \multirow[b]{2}{*}{ Case } & \multicolumn{2}{|c|}{ Thickness $(\mathrm{cm})$} & \multirow{2}{*}{$\begin{array}{l}\text { Maximum } \\
\text { dose rate } \\
(\mathrm{R} / \mathrm{h})\end{array}$} \\
\hline & Iron & Lead & \\
\hline $\begin{array}{l}1 \\
2 \\
3\end{array}$ & $\begin{array}{l}1.0 \\
1.0 \\
1.0\end{array}$ & $\begin{array}{l}0.0 \\
1.25 \\
\text { Filling } \\
\text { void space }\end{array}$ & $\begin{array}{r}12,340 \\
2,650 \\
1,860\end{array}$ \\
\hline
\end{tabular}

Table C-2 demonstrates that adding a lead sheath inside a thin-walled container (Case 2) reduces the dose rate by $79 \%$. Further filling of the spent-fuel region with lead (Case 3 ) reduces the dose rate by $85 \%$ from the no-lead case (Case 1 ).

\section{Conclusions}

The gamma dose rate on the outside of thin walled containers is very much lower when a lead liner or filler is used. If site characterization studies reveal unanticipated conditions that indicate the need for radiation shielding, then lead could be useful as a filler or (preferably) as a liner material. However, materials other than lead may be equally or more effective than lead in these applications and such materials would also merit consideration. 


\section{REFERENCES}

Chilton, A. B., J. K. Shultis, and R. E. Faw, 1984. Principles of Radiation Shielding, Prentice-Hall, Inc., Englewood Cliffs, N.J.

Engel, R. L., J. Greenborg, and M. M. Hendrickson, 1986. ISOSHLD--A Computer for General Purpose Isotope Shielding Analysis, BNWL-236, Battelle Northwest Laboratory, Richland, Wash.

Jansen, G., 1987. Expected Nuclear Waste Repository Waste Package Performance in Three Salt Formations, BMI/ONWI-655, Battelle Memorial Institute, Office of Nuclear Waste Isolation, Columbus, Ohio, August. 


\section{INTRODUCTION}

In general, lead and its alloys do not possess the level of mechanical strength required of a construction material. The metal is soft, malleable, easily abraded and creeps at relatively low stress levels even at room temperature. Work hardening may help in the short term, but it is not a permanent solution as lead self anneals with time (Lusk, 1984).

The yield strength and tensile strength are very inferior to that of steel (Table D-1). In the United States, the license reviewers of spent-fuel transportation casks allow $204 \mathrm{~kg} / \mathrm{cm}^{2}(3,000 \mathrm{psi})$ as the yield strength of lead (Lusk, 1984). With increasing temperature the tensile strength rapidly deteriorates due to the metal's low melting point. It is because of the low strength and other poor mechanical properties that lead has not been considered to be suitable as a container material.

More interesting from a structural point of view is the compressibility of lead under hydrostatic load. Its compressibility is rather low, providing good resistance to volume reduction. Lead's low compressibility is most important for waste package designs using lead as a filler material in thin-walled containers under a hydrostatic load (e.g., the Canadian design), In these designs, if void space is eliminated, lead cuuid prevent excessive deformaticn of the thin shell.

LEAD FOR INNER STRUCTURAL SUPPORT

The general problem of internal structural support is not expected to be relevant to the U.S. program. The Yucca Mountain project is considering the use of thin-walled containers because the external pressure is expected to be only 1 atmosphere.

\section{INTERNAL STRESSES FROM LEAD EXPANSION WITH TEMPERATURE}

A pertinent question to the U.S. repository is whether the expansion of lead with temperature may generate undesirably high internal stresses. Lead has a large linear thermal expansion coefficient, about two times larger than steel (Table D-2). When converted to a volumetric expansion coefficient, this may result in large internal pressurization stresses if lead has no place into which it can expand upon heating. 
Table.D-1. Mechanical properties of some lead and ferrous alloys at room temperature (CRC, 1983).

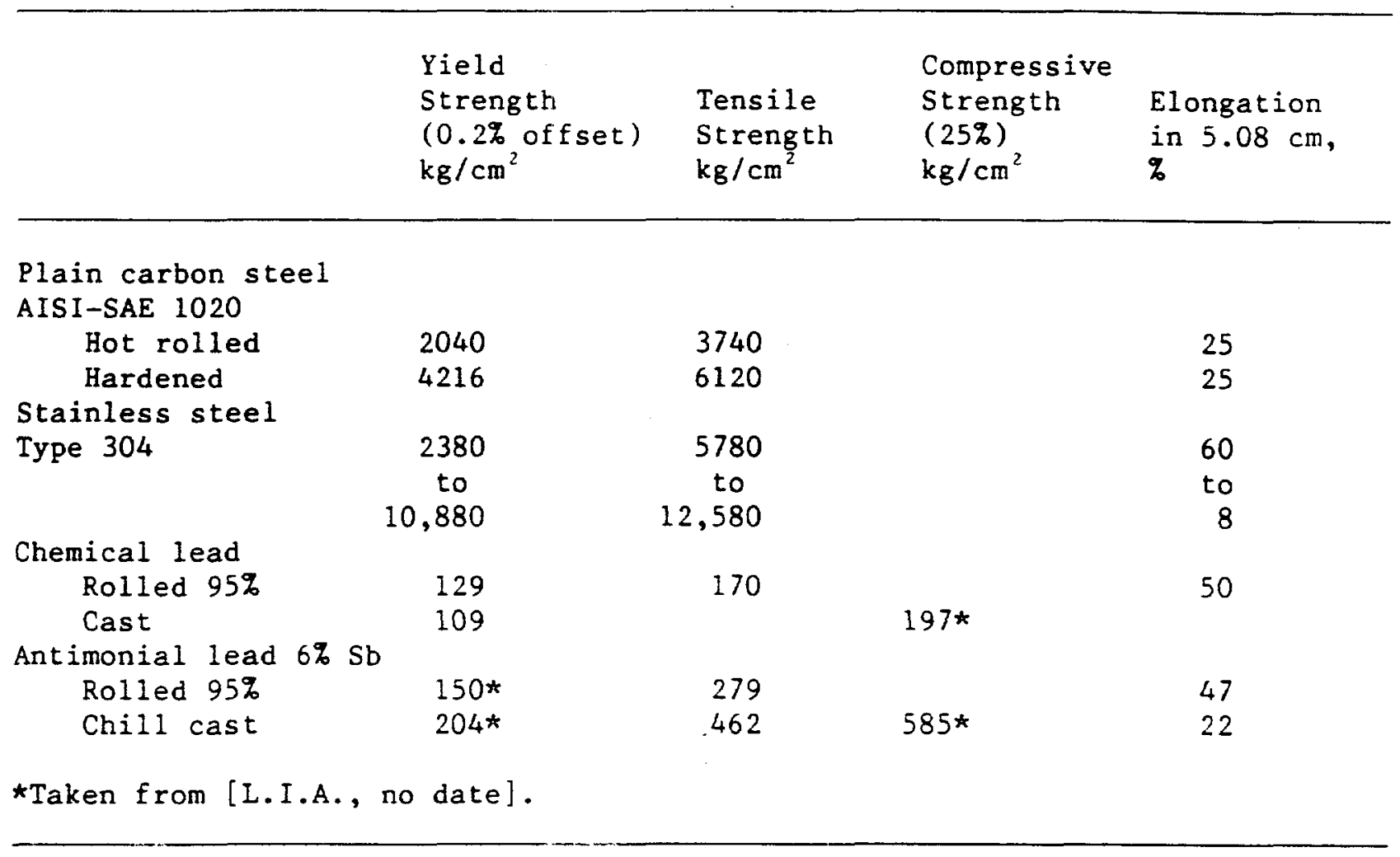

Table D-2. Thermal expansion coefficients.

Pure lead

$16.4 \times 10^{-6} /{ }^{\circ} \mathrm{F}$
Stainless steel

$9.6 \times 10^{-6} /{ }^{\circ} \mathrm{F}$
Carbon stee 1

$6.7 \times 10^{-6} / \circ \mathrm{F}$

Cripps performed a finite element analysis of the temperature loading of a thin-shelled titanium container with a lead filler surrounding a canistered glass waste form (Cripps, 1985). Assuming all materials to be perfectly elastic, he found that "[F]or temperature loading, the relatively large differences in coefficients of expansion between lead and the other materials considered cause high tensile stresses in the titanium container. In fact the lead filler dominates the performance of the container and produces the sort of behavior which would be expected from internal pressurization." Cripps found also that the peak stresses are obtained at the container ends. The peak stresses due to a temperature rise of $75^{\circ} \mathrm{C}$ were calculated to be about $2400 \mathrm{~kg} / \mathrm{cm}^{2}$. Although Cripps analysis cannot be termed as definitive it is obvious that very large stresses can be developed if lead is not allowed to expand freely. This would be especially important in L.S. designs where the 
temperature increase after emplacement can be as high as $200^{\circ} \mathrm{C}$. High tensile stresses at the container welds would promote stress corrosion cracking and local embrittlement of the steels in the presence of lead. Also, with spent fuel as the waste form, high internal compressive stresses within the lead would be transferred to the claddings, which could fail for lack of internal support (LWR spent fuel has an internal void fraction in excess of 5\%).

It appears from the above analysis that the large differences in the coefficient of thermal expansion between lead and commonly considered container materials is an undesirable property of lead. High stress levels from thermal expansion could be remedied by providing space for lead to expand during the peak thermal period. Another method to avoid temperature stresses might be to use a lead alloy with thermal expansion properties closer to that of the container material or an alloy with a negative thermal expansion coefficient. Lead-tin-bismuth alloys do have a negative thermal expansion coefficient. However, a proper alloy should still have other desirable properties. The Swedes and Canadians both recommend using high purity lead to minimize casting problems such as shrinkage defects.

\section{LEAD ON THE EXTERIOR OF A WASTE CONTAINER}

Lead creep under shear

A design using lead on the outside of the container has been suggested in the past (DOE, 1980), although we are aware of no analysis addressing the use of lead as an integral part of the waste container.

At room temperature reported values for the shear modulus of lead vary between 55,000 and $78,000 \mathrm{~kg} / \mathrm{cm}^{2}$. At higher temperatures, measurements on wires freannealed in air gave the values for the shear modulus, $G$, shown in Table D-3.

Table $D-3$. Shear modulus of lead at various temperatures

\begin{tabular}{lcccccc}
\hline T in ${ }^{\circ} \mathrm{C}$ & 20 & 50 & 100 & 150 & 200 & 235 \\
$\mathrm{G}$ in $\mathrm{kg} / \mathrm{cm}^{2}$ & 78,000 & 74,300 & 66,700 & 59,700 & 53,900 & 24,400 \\
\hline
\end{tabular}


The shear modulus of lead is seen to decrease monotonically with increasing temperature. These data point to a sharp decrease in the shear modulus above $200^{\circ} \mathrm{C}$.

For 1-mm grain size pure lead, published deformation maps indicate that $1 \%$ lead creep will occur after 3.2 years at $100^{\circ} \mathrm{C}$, after 23 days at $150^{\circ} \mathrm{C}$, and after 3 hours at $250^{\circ} \mathrm{C}$ (Frost and Ashby, 1973). It is clear that, for a design employing lead on the exterior surface of the container, the temperature should be kept as low as possible and that it should never exceed $200^{\circ} \mathrm{C}$. If enough room were around the container to accommodate creep, lead could flow away from the surface.

It should be noted, further, that under nonuniformly distributed external loads, localized thinning of the lead would occur. 
REFERENCES

AIP (American Institute of Physics), 1972. American Institute of Physics Handbook, 3rd edition, McGraw Hill Inc., New York.

Da C. Andrade, E. N., 1952. "The Flow of Metals," Sixth Hatfield Memorial Lecture, Journal of the Iron Steel Institute, July 1952, pp. 217-228.

Da C. Andrade, E. N., and K. H. Jolliffe, 1960. "The Flow of Polycrystalline Metals Under Simple Shear II," Proc. Roy. Soc. A., Vo1. 254, pp. 291-315.

Da C. Andrade, E. N., 1961. "Creep of Metals under Simple Shear," Nature, pp. $31-432$.

Da C. Andrade, E. N., and K. H. Jolliffe, 1963. "The Flow of Polycrystalline Metals Under Simple Shear II," Proc. Roy. Soc. A., Vol. 271, PP. 472-499.

Da C. Andrade, E. N., 1963. "An Apparatus for Investigating Flow of Metals Under Simple Shear," J. Sci. Instrum., Vol. 40.

Da C. Andrade, E. N., and D. Margrave, 1968. "The Flow of Polycrystalline Lead Under Simple Shear at Higher Temperatures," Proc. Roy. Soc. A, Vol. 304 , PP. 1-24.

Da C. Andrade, E. N., and V. M. Morton, 1968. "The Distribution of Orientation of Slip Bands in lead Subjected to Pure Shear," Phil. Mag., Voi. 18, PF. 425-429.

Bolz, R. E., and G. L. Tuve, Eds., 1983. CRC Handbook of Tables for Applied Engineering Science, 2nd edition, CRC Press, Inc., Boca Raton, Fla.

Cripps, J. E., 1985. "The Design of Nuclear Waste Containers and Irradiated Fuel Transport Flasks," in Lead: Its Role in Nuclear Waste Management, Lead Development Association, London, England.

Frost, H. J., and M. F. Ashby, 1973. A Second Report on Deformation Mechanism Maps, Office of Naval Research, Report Ad-769821.

Gmelins Handbuch, "Blei," Part B1, Verlag Chemie-GmbH, Weinheim Bergstrasse, 1972.

Hofmann, W., and P. Wehr, 1965. "Das Verhalten von Homogenverbleiungen bei Temperaturewechse1- und Dauerschwingbeanspruchung," Metal1, No. 8, pp. 811-817.

Lead Industries Association, Inc., no date. Lead for Corrosion Resistant Applications--A Guide, 292 Madison Ave., New York. 
Lusk, E. C., 1984. "Use of Lead in the Nuclear Industry," in Proceedings of $\frac{56 \text { the Annual Meeting of Lead Industries Association, Denver, Colo., April }}{2-4}, \frac{1984 .}{}$

Reinert, M., 1968. "Homogeneous Lead for Corrosion Protection," in Lead '68, Third International Conference on Lead, Venice, Italy, September 1968.

Reinert, M., 1971. "Entwicklungstendenzen in der Anwendung and Weiterverarbeitung van Blei," Erzmetal1, Vol. 24, pp. 361-416.

Staten Kaernkraftinspektion (Swedish Nuclear Power Inspectorate), 1984. Review of Final Storage of Spent Nuclear Fuel - KBS-3, Technical Report SKI 84:5.

Smith, J. F., and R. R. Kubaiak, 1979. "Lead and Lead Alloys," in Metals Handbook, 9the Edition, Vol. 2, American Society for Metals, Metals Park, Ohio.

DOE (U.S. Department of Energy), 1980. USNRC Waste Confidence Rulemaking and Statement of Position of the USDOE, DOE/NE-0007 Washington, D.C.

Wests :in, J. H., et al., 1983. "Water Migration Through Compacted Bentonite Backfill for Containment of High-Level Nuclear Waste," Nuclear and Chemical Waste Management, Vol. 4, No.4, pp. 291-299.

$-66-$ 


\section{PROGRESS IN CASTING TECHNOLOGY AND VOID REDUCTION}

The Swedes (Nordesjo, 1978; Werme, 1984) and the Canadians (Nuttall, 1983; Mathew, 1984, 1985a,b, 1986a, 1987a,b) have investigated the casting of lead into metal containers. The Belgians have investigated the casting of lead onto compacted spent-fuel hulls (De Regge, 1984).

The Swedes (Werme, 1984) have conducted half-scale experiments using unirradiated Zircaloy rods and two casting techniques. The first technique used a two-step casting procedure based on radial cooling. High-purity lead (HPOF quality) is cast at $350^{\circ} \mathrm{C}$ while the copper container and simulated fuel temperatures are at approximately $380^{\circ} \mathrm{C}$. During cooling the different materials shrink at a rate determined by their thermal expansion coefficients. Lead shrinks another $3.4 \%$ upon solidification. As the temperature reaches $320^{\circ} \mathrm{C}$, there are defects near the central section of the container due to the radial cooling. The lead near the center is then remelted by raising the temperature to $330^{\circ} \mathrm{C}$, and new casting of lead is performed.

The second technique uses single-step casting and is implemented through a careful control of the rate of cooling along the length of the container. The rate of cooling was chosen such that the total solidification time was ninimized while preventing extensive void formation.

Both techniques resulted in $98.5-99 \%$ filling of the container. For the two-step casting procedure, the void space was located primarily between the copper container and the metal matrix. In the single-step casting technique the void space was smaller between the copper and the lead, but larger between the simulated fuel pins and the lead matrix.

In Canada lead casting tests have been done with small and half scale containers. In one series of tests casting between unirradiated fuel pins was also demonstrated. The small-scale testing implemented a single-step casting procedure to $\mathrm{fill}$ empty containers $(15 \mathrm{~cm}$ in diameter and more than $60 \mathrm{~cm}$ high) with pure lead. Two different cooling techniques were investigated. In the first case, the bottom of the container was water cooled and the sides were air cooled. This unidirectional cooling technique tended to form a shrinkage cavity in the upper third of the container (Mathew, 1985b). In the second case, cooling water was circulated along the bottom and lower half of the container. The container top and upper third were insulated, while the remaining section was air cooled (Mathew, 1984). This cooling scheme (multidirectional cooling) was selected based on modeling results which showed that this approach would minimize the total solidification time, thereby reducing the interaction time between the molten metal and the container material. The 
results indicate that voids could be prevented from forming. There remained however a small shrinkage gap between the container metal (304 stainless steel in this experiment) and the lead. These studies also showed that the fuel rods need to be preheated to at least $330^{\circ} \mathrm{C}$ to prevent premature solidification of the lead.

The Canadians also ran larger scale prototype container casting experiments in which 99.9 wt\% pure lead was cast into ASTM Grade-2 titanium shells which were $60 \mathrm{~cm}$ in height and $40 \mathrm{~cm}$ in diameter (Mathew, 1986a). Both unidirectional and multidirectional cooling techniques were used. Void free castings were obtained in both cases. Use of multidirectional cooling reduced the casting time from 6000 to 2300 seconds. The air gap between the lead matrix and the container, however, could not be eliminated (Mathew, 1987a). Mathew recommends the use of multidirectional cooling should Canada decide to implement the lead matrix design for full-scale application.

In another smal1-scale experiment, an unirradiated 37-element Bruce fuel bundle was specially prepared for casting (Mathew, 1986a). The fuel bundle was preheated to $55^{\circ} \mathrm{C}$ above the melting temperature of lead to prevent premature solidification on the fuel pins and the multidirectional cooling scheme was applied. The results of this test showed that lead could be successfully cast between the unirradiated fuel pins.

The Belgians plan to reprocess spent fuel and dispose of the fuel cladding hulls and metallic structural components through compaction and geologic disposal (De Regge, 1984; SCK/CEN, 1986). One concept under study, which was later abandoned, was the encapsulation of these wastes in a lead matrix in a metallic container. The Belgian studies are especially important in that they are the only ones in which actual, irradiated $z$ ircaloy hulls were user.

Studies of casting of lead on compacted spent fuel hulls were begun in 1976 (Broothaerts, 1977). In these experiments, $\mathrm{Pb}-1.5 \% \mathrm{Sb}$ was cast onto the fuel hulls either under atmospheric pressure or under vacuum. In the air casting, void spaces ranged from 15 to 18\%. This was attributed to air bubbles trapped in the irregularly deformed tube sections. Vacuum casting provided much better filling of the voids, with average void spaces of $3.5 \%$. This study and a later study (De Regge, 1984) of the encapsulation of the spent fuel hulls in $\mathrm{Pb}-1.5 \% \mathrm{Sb}$ and $\mathrm{Pb}-4 \% \mathrm{Sn}-12 \% \mathrm{Sb}$ alloys indicated that lead would not wet the oxidized Zircaloy hulls and a small gap between these materials always existed. Also, slagging took place requiring secondary waste treatment of the particulate contamination which accumulated on top of the casting (De Regge, 1984].

Lead wetting of oxidized, irradiated Zircaloy is poor to non-existent (De Regge, 1984), and voids and shrinkage gaps must be expected along irradiated fuel pins. Wetting by pure lead is also poor for oxidized copper (Werme, 1984), stainless steel 304 and 316, grade 12 titanium, and Inconel 625 (Mathew, 1985b), Pb-1.5\% Sb did bond to Inconel 718 and AISI 302 but only after several hours at $450^{\circ} \mathrm{C}$ (De Regge, 1984).

The lack of wetting may be particularly troublesome for Zircaloy because it implies that preferential pathways for water flow may form along the fuel rods. Voids, if extensive, may also impair heat transfer and the structural support function. 
Heating of the fuel will cause the internal fission gas pressure within the fuel rods to increase. The problem is especially important for PWR $f$ uel rods, which operate with an initial helium overpressure.

Calculations indicates that raising the fuel temperature to $400^{\circ} \mathrm{C}$ would cause the pressure in a PWR fuel rod to reach 120 bar (Nordesjo, 1978). This results in a "ring strain of $11 \mathrm{kp} / \mathrm{mm}-\mathrm{mm}$. The PWR rods are however supposed to resist strains up to $30 \mathrm{kp} / \mathrm{mm}-\mathrm{mm}$ without exceeding the extension limit."

In a study of gas pressurization of unirradiated, stress relieve Zircaloy-4 rods (Fish et al., 1982), the rods were pressurized with helium to 650 psi. This was the pressure calculated to exist in a fuel rod at room temperature after three cycles in a PWR. After pressurization, the diameter was measured and the rod was heated. to the selected test temperature $\left(486-652^{\circ} \mathrm{C}\right)$ for 16 hours. After heating, the rod diameters were again measured and the strain (defined as (D2-D1)/D1, where D1 and D2 are the diameters before and after heating, respectively) was calculated. On the basis of test results (Table $E-1)$, it was recommended that, in order to prevent $18 \%$ strain of the Zircaloy rods, the casting temperature of any metal matrix should be below $650^{\circ} \mathrm{C}$.

The above calculations, however, did not take into account the mechanical properties of irradiated fuel claddings. These are known to be much more fragile and brittle than unirradiated claddings. Further investigation of this matter is warranted, should designs employing casting be considered.

\section{SHR INKAGE GAP}

The lead casting experiments have shown that a shrinkage gap is not eliminated. Indeed the formation of a shrinkage gap could be accentuated in the presence of irradiated Zircaloy claddings.

Table E-1. Measured strain in pressurized unirradiated stress-relieved Zircaloy rods as a function of temperature ${ }^{a}$

Temperature

$\left({ }^{\circ} \mathrm{C}\right)$
Strain

(\%)

$\begin{array}{rr}486 & 1.6 \\ 540 & 3.7 \\ 594 & 8.0 \\ 652 & 16.7\end{array}$

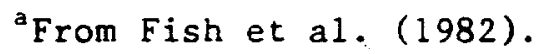


The presence of a shrinkage gap is detrimental to heat transfer. In the Canadian program it has been found that the air in the shrinkage gap would control the transfer of heat from the lead matrix to the outside container (Mathew, 1984). Small gaps along the fuel rods may form preferential channels to groundwater. This could be of concern to the Yucca Mountain site, where the host rock is believed to be partially saturated with water, should designs with a cast filler be considered.

\section{INTERACTIONS WITH OTHER WASTE-PACKAGE MATERIALS DURING CASTING}

During casting the molten lead may interact chemically with the container and canister materials or with the irradiated claddings. For this reason, it is desirable to have the solidification time be as brief as possible (Mathew, 1985b).

In the Belgian study it was found that molten lead interacts with the urano-zirconate inner layer of the cladding hulls which contains fission products and actinides (De Regge, 1984). Although the nature of the interaction is not fully understood, it was consistently observed that radionuclides formerly insoluble in nitric acid could be easily dissolved in natural waters after the interaction with molten lead took place. This was particularly true for cesium and to a lesser extent for ruthenium and cerium. Furthermore, the molten lead cladding interaction produced slagging which required decontamination of the upper layers of the casting and produced secondary waste. Although the reason for removing the slag is not reported, it is likely that it may interfere with the welding of the canister. Thus, either the slag is treated, producing a secondary waste stream, or void space is left on top of the casting so that the slag cannot contaminate the weld area. The problem has not been reported to occur in the Canadian and Swedish programs. These, however, only dealt with "clean" unirradiated specimens in reduced scale tests. The Belgian studies show that radioactive corrosion products and radioactive particulates may separate from the Zircaloy surface and be dispersed in the lead or brought to the surface of the melt in the slag. Besides complicating the studies of the release of radionuclides from the waste package, this finding could cause difficulties for the U.S. waste program because of the requirement to maintain the option of waste retrieval for 50 years from the beginning of waste-emplacement operations. The U.S. program would have to consider remelting of the lead and regenerating or disposing of large amounts of lead contaminated with highly radioactive products.

\section{NONDESTRUCTIVE TESTING}

No technique appears to be available for nondestructive testing of the quality of the casting for the present application of lead. Ultrasonic testing cannot be applied because of the presence of shrinkage gaps and of gaps and voids in the spent fuel. A Canadian report presents preliminary results of a technique for void detection which utilizes fast neutron ( $14 \mathrm{MeV}$ ) 
attenuation (Montin, 1987). Voids were detected in lead castings of $15 \mathrm{~cm}$ and $40 \mathrm{~cm}$ diameter. The smallest void was in the form of a cylinder $1.2 \mathrm{~cm}$ in diameter and $7.5 \mathrm{~cm}$ long. No material other than lead was present in the casting. Although no absolute detection limit was determined, and despite the simplicity of the system when compared to an actual container filled with waste, "...the results show that is not possible to use a simple attenuation formula to determine accurate void size in large castings because of multiple scattering of neutrons into the detector." A practical system would have to accommodate several complicating factors, such as (1) the presence of uranium238, which is the largest component of spent fuel, and other actinides which fission when exposed to fast neutrons and emit extra neutrons themselves; (2) the neutrons emitted in spontaneous fissions; (3) the presence of gaps and voids within the fuel pins themselves, and (4) the inhomogeneity of the system. Also, the fact that a fast-neutron source is needed in itself a further limitation, since fast neutrons are obtained either in a fast reactor or with accelerators, such as a Cockcroft accelerator. In the latter instance problems of intensity of the neutron flux may arise. It appears therefore that a large effort would be needed to develop and demonstrate an acceptable technique for detecting casting defects.

A further aspect which deserves consideration is that of void elimination once they have been discovered. Referring to voids in lead shielding in spent-fuel shipping casks, one lead consultant says: "If a void is found, it is difficult to repair, especially since there is a requirement for the protection of the 2-inch thick stainless steel shell that it not be heated above $800^{\circ} \mathrm{F}^{\prime \prime}$ (Lusk, 1984 ).

A similar concern would apply for waste-container sensitization, although iechniques may be available to obviate this problem. Reheating of the casting would result in grain growth, which is not desirable for corrosion resistance. This phenomenon would also have to be addressed if credit were to be sought for lead as a corrosion barrier.

\section{HOT-CEIL LIMITATIONS}

To date, there is no experience with full scale casting of lead into a container with irradiated $f$ uel rods in a hot cell. "The problems of filling container voids at this temperature, $330^{\circ} \mathrm{C}$, in a heavily shielded work cell should not be underestimated" (Cripps, 1984). The DOE is not aware of any studies that have examined this problem. One aspect that would have to be investigated, which is especially important for consolidated fuel, is how to prevent the fuel from moving upwards in the molten lead due to a bouyancy effect.

MACROSCALE AND MICROSCALE SEGREGATION AND GRAIN-STRUCTURE CONTROL

The control of grain structure and impurities segregation during solidification is difficult. Solute segregation can be expected both on a 
macrosale (waste-package diameter) and on a microscale (grain boundaries) (Mathew, 1986b). Segregation of impurities at the grain boundaries can have adverse effects on the physical and corrosion properties. It has been recommended that lead grain boundaries should be free of impurities to enhance corrosion resistance (Hofmann, 1970).

Also, the casting techniques that are favored at present contemplate directional cooling of the melt. Cooling may take place radially inward, axially, or in a combination of both directions. Directional solidification produces columar grains oriented parallel to the direction of cooling. Radial cooling would result in columnar grains perpendicular to the spent fuel. Axial cooling would result in columar grains parallel to the spent fuel. In multidirectional cooling the preponderance of one direction over the other varies along the length of the casting. An oriented grain structure reduces the corrosion resistance along the direction of orientation should intergranular corrosion occur (Krysko, 1985). During casting, large grains (2 $\mathrm{cm}$ or more in length) will form, as shown in axial and multidirectional cooling experiments in Canada (Mathew, 1984). (Even larger grains would be formed in full-scale tests because of slower cooling than in small or half scale tests) the presence of large grains is known to favor intergranular attack. An equiaxed, fine structure would be a better choice for corrosion resistance (Krysko, 1985). The latter, however, cannot be accomplished with directional cooling. 


\section{REFERENCES}

Broothaerts, J., L. De Wilde, and F. Casteels, 1977. "Cladding Waste Compaction and Encapsulation in Lead," in Treatment, Conditioning and Storage of Solid Alpha-Bearing and Cladding Hulls, OECD Nuclear Energy Agency, Paris, France.

Cripps, J. E., 1984. "The Design of Nuclear Waste Containers and Irradiated Fuel Transport Flasks," in Lead: Its Role in Nuclear Waste Management, Lead Development Association, London, England.

De Regge, P., J. Broothaerts, and F. Casteels, 1984. "Encapsulation of Cladding Waste by Lead Alloys," in Lead: Its Role in Nuclear Waste Management, Lead Development Association, London, England.

Fish, R. L., N. Wynhoff, and V. J. Ferre11, 1982. Spent LWR-Fuel Waste-Package-Stabilizer Recommendations, Hanford Engineering Development Laboratory, HEDL-7204, Richland, Wash.

Hofmann, W., 1970, Lead and Lead Alloys - Properties and Technology, English translation of the second revised German edition, Lead Development Association, Springer-Verlag, New York.

Lusk, E. C., 1984. "Use of Lead in the Nuclear Industry," in Proceedings of the 56 the Annual Meeting of Lead Industries Association, Denver, Colo. 1984.

Mathew, P. M., and P. A. Krueger, 1984 "Metal Matrixing of Used Nuclear Fuel With Particular Reference to Lead," in Lead: Its Role in Nuclear Waste Management, Lead Development Association, London, England.

Mathew, P. M., M. Taylor, and P. A. Krueger, 1985. Heat Transfer Coefficients for Lead Matrixing in Disposal Containers for Used Reactor Fuel, AECL-8365, Atomic Energy of Canada Limited, Pinawa, Manitoba.

Mathew, P. M., and P. A. Krueger, 1985. "Metal Matrix Integrity and Related Technology Development in the Canadian Nuclear Fuel Waste Management Program," in Scientific Basis for Nuclear Waste Management, Vol. 26, p. 583.

Mathew, P. M., 1986a. "Investigations on Metal Matrices for Nuclear Fuel Waste Disposal," Paper presented at the Second International Conference on Radioactive Waste Management, Winnipeg, Canada, September 7-11, p. 558.

Mathew, P. M., 1986b. Casting Properties of Metal Matrices for Nuclear Fuel Waste Disposal: Review and Assessment, AECL-TR-371, Atomic Energy of Canada Limited, Pinawa, Manitoba.

Mathew, P. M., and P. A. Krueger, 1987a. "Casting development for Nuclear Fuel Disposal Containers," Canadian Metallurgical Quarterly, Vol. 25, No. 4 
Mathew, P. M., 1987, private communication in a teleconversation with Claudio Pescatore, Brookhaven Natinnal Laboratory.

Montin, J. L., et al., 1987. The Detection and Gauging of Voids in Lead Castings With 14-MeV Neutrons, AECL-TR-423, Atomic Energy of Canada Limited, Pinawa, Manitoba.

Nordesjo, E., 1978. Safety Analysis of the Encapsulation of Irradiated Fuel Elements in Copper Containers, ASEA-ATOM 1978-03-20, KBS-TR-112, Stockholm, Sweden.

Nuttall, K., et al., 1983. "The Canadian Container Development Program for Fuel Isolation," in Scientific Basis for Nucllear Waste Management, Vo1. 15, Pp. 677-684.

SCK/CEN, 1986. MOL Research Division Report, July 1-December 31, 1985 , Chapter 4 , p. 73 .

Werme, L. 0., and A. Bergstrom, 1984. "Lead Quality Criteria and Containment Technology for the Disposal of High-Level Nuclear Waste," in Lead: Its Role in Nuclear Waste Management, Lead Development Association, London, England. 
Appendix F

COSTS OF USING LEAD IN WASTE PACKAGES

\section{COSTS OF MATERIALS}

This appendix presents estimates of the costs of using lead in waste packages for a repository at Yucca Mountain, Nevada. These estimates are based on the void space in the waste package, the current cost of lead, and a total of 114,282 assemblies of PWR spent fuel and 130,404 assemblies of BWR spent fuel. The assumptions about the numbers of spent-fuel assemblies are based on the statutory limit $(70,000$ metric tons of heavy metal) on the quantity of waste that may be disposed of in the first repository until the second repository begins operations and on a forecast (DOE, 1988a) of the spent-fuel types the DOE expects to receive.

Three design configurations were considered: packages for consolidated spent fuel, packages for nonconsolidated (intact) spent fuel, and hybrid packages. Potential configurations for consolidated-fuel and nonconsolidatedfuel packages are shown in Figure 2 of the text. The hybrid container configuration is designed to accommodate the mix of PWR and BLR assemblies to be received at the repository; it accomnodates three intact $P W R$ assemblies and four intact BWR assemblies in a disposal container with a diameter of 28 inches. The distribution of the 114,282 PWR assemblies and the 130,404 BWR assemblies for the consolidated-fuel case (Scenario 5 in a recent DOE study designated Task $B$ in the MRS systems studies) is shown in Table F-1.

Proceuires, including the assumptions used for calculating the volume and cost of leat in the various types of containers, are given in Table F-2, and a sumary of the lead costs for this case in which most of the spent fuel is consolidated is given in Table F-3.

Lead costs for the case of all intact container (configurations 3 and 4 in Figure $F-1$ ) for the same number of assemblies as above can be derived from the procedures of Table $F-2$. The results for this case of all intact assemblies are given in Table F-4.

Finally, a scenario involving the use of a hybrid container configuration (see Figure $F-2$ ) is currently under consideration by the Yucca Mountain Project and is included in the above referenced MRS System Study as Scenarios No. 2 and No. 4. The distribution of assemblies for this case is given in Table F-5, but since the total number of assemblies is lower than in Table $F-1$, an additional 2051 hybrid packages have been added to accommodate 8204 BWR and 6153 PWR assemblies and an additional 5198 configuration 4 (intact) packages have been added to accommodate 15,594 PWR assemblies. The adjusted distribution of assemblies is shown in Table F-6.

The container size is somewhat larger for the hybrid container, but the procedure for calculating the amount and cost of lead that would be employed in this scenario is similar to the previous one and is outlined in Table F-7. The summary of lead costs for this scenario is presented in Table F-8. 


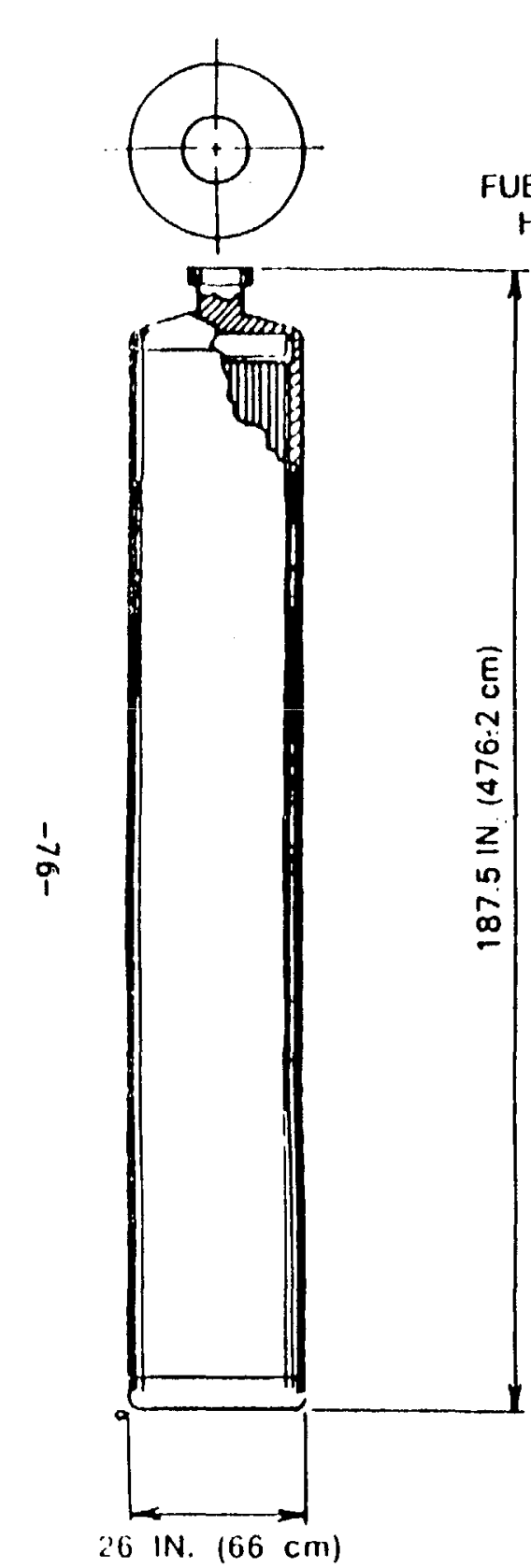

RODS FROM 1 PWR

FUEL ASSEMGLY

FUEL ASSEMBLY

HARDWARE

DDARE

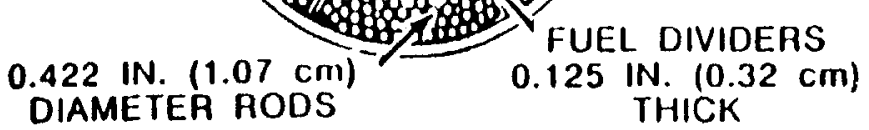

CONFIGUAATION 1.

SIX CONSOLIDATED PWA ASSEMBLIES

6 BWR FUEL ASSEMBLIES

$5.5 \times 5.5 \mathrm{IN} .(14 \times 14 \mathrm{~cm})$

26 IN. $(66 \mathrm{~cm})$

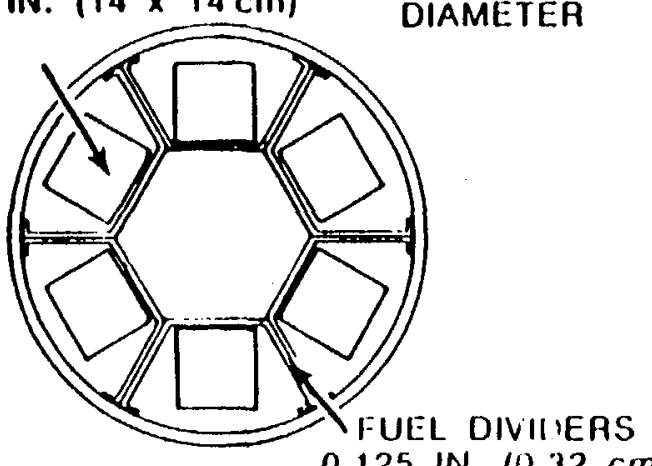

$0.125 \mathrm{IN} .(0.32 \mathrm{~cm})$

THIICK

CONFIGURATION 3

SIX INTACT BWA ASSEMBLIES

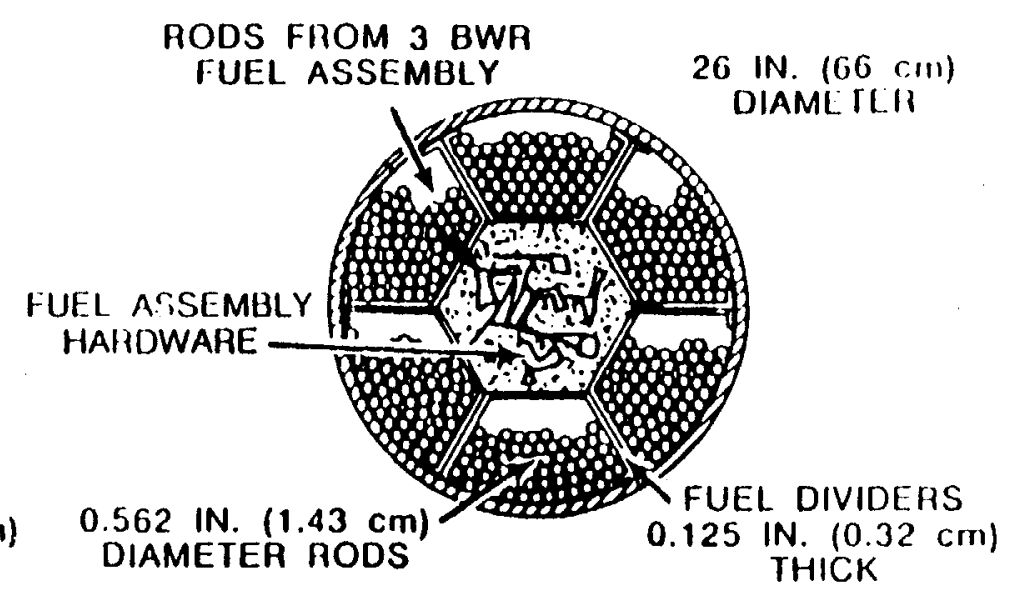

CONFIGURATION 2

EIGHTEEN CONSOLIDATED BWR ASSEMBLIES

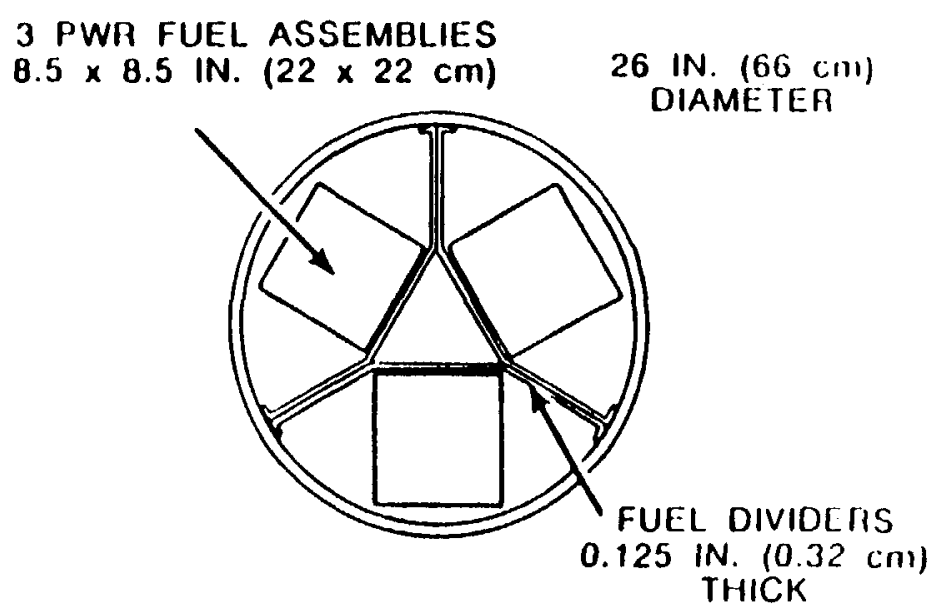

CONFIGUAATION 4.

THREE INTACT PWA ASSEMBLIES

PWR - PRESSURIZED WATER REACTION UWR . BOILING WATER REACTOH

Figure F-1. Yucca Mountain Project reference spent fuel consolidation and intact container configurations 


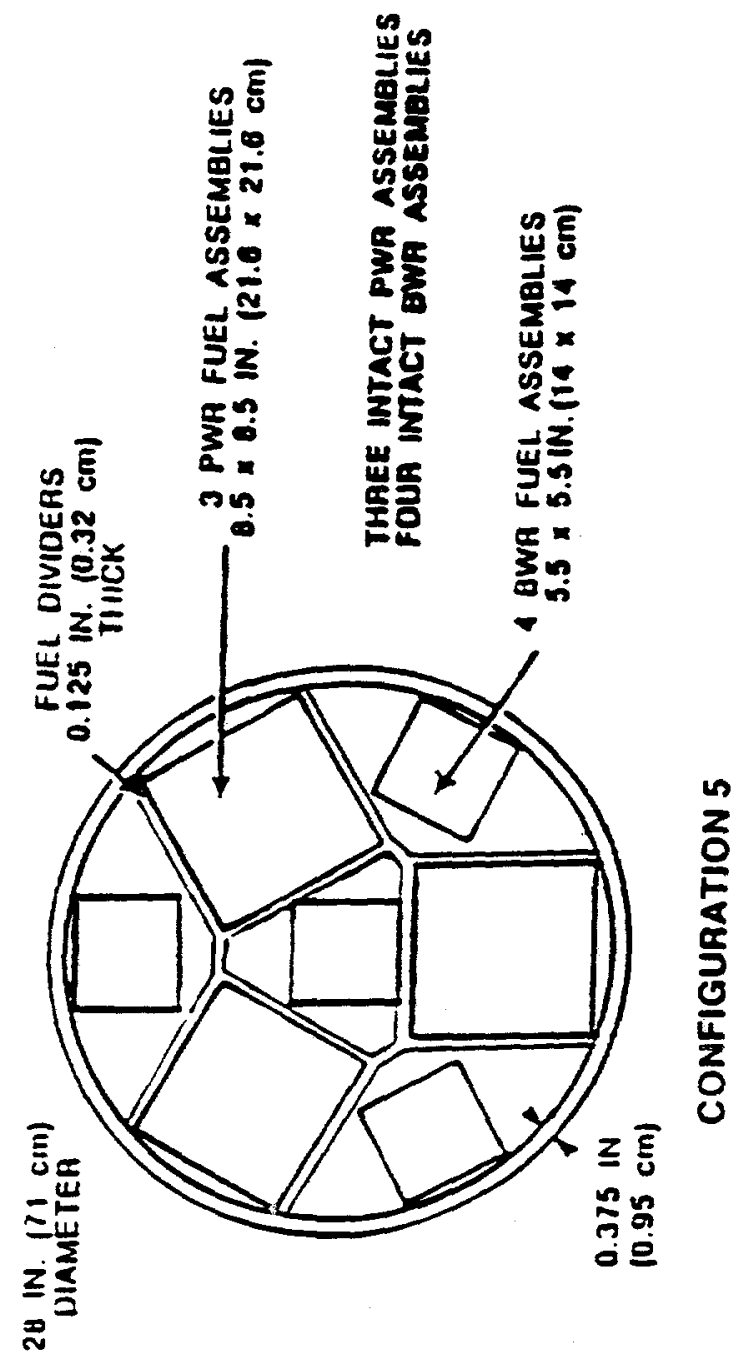

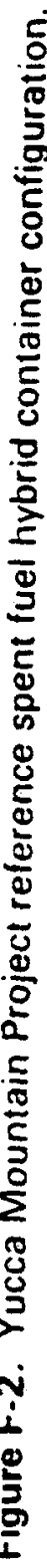


The cost of a lead liner was calculated for a closed cylinder with 1.25 $\mathrm{cm}$ thick walls and $178 \mathrm{~cm}$ high. At $\$ 0.42$ per pound (personal communication from M. J. Hadwin, Federal Industrial Services, Inc., November 1988), the material cost is about $\$ 1450$. Adding estimated manufacturing and handing costs at $\$ 1000$ results in a total liner cost of about $\$ 2500$. Space occupied by the lead liner would necessitate a greater number of packages (5\%), 1370 more packages than the 27,359 given for the consolidated case. The total cost for 28,729 liners is $\$ 71.8$ million. The additional containers (1370) and the associated emplacement operations would cost approximately $\$ 75$ million (based on the current $\$ 1.5$ billion estimate), for a total liner cost impact of $\$ 146$ million.

\section{COSTS OF RESEARCH AND DEVELOPMENT}

The research-and-development tasks together with preliminary DOE cost estimates that would be required to resolve the technical concerns related to the use of lead in the waste package are as follows:

1. A series of corrosion tests would be required to evaluate the oxidation and aqueous corrosion resistance of appropriate lead alloys under repository-relevant (including irradiation) conditions--that is, at temperatures over the range $50-250^{\circ} \mathrm{C}$ and for times long enough to establish the kinetics of degradation behaviors. This task is estimated to cost about $\$ 500,000$ and take 3 years to complete.

2. A series of studies of the segregation of chemical species within the lead alloys considered for container-use would : needed to determine the occurrence of segregation of alloying additions or impurities under repository-relevant conditions i.e. temperatures of $50-250^{\circ} \mathrm{C}$ and time long-enough to establish the grain growth kinetics and the reaction rates of any relevant phenomena. This task is expected to take 1 year to complete and cost $\$ 150,000$.

3. The possibility of intergranular attack of lead-based alloys must be considered in 1 ight of the very large grain sizes that will be produced in lead either by directional casting procedures or by the long-term thermal exposures that are expected under repository- relevant conditions. The needed understanding of intergranular corrosion in lead alloys would be attained by evaluating the effects of temperature $\left(50-250^{\circ} \mathrm{C}\right)$ and impure ground water at (at temperatures below $100^{\circ} \mathrm{C}$ ) for times long enough to establish a range of expected stable grain sizes. Assessment of the importance of intergranular attack in waste package designer must also be done. These tasks would require about 2 years and cost $\$ 300,000$.

4. It would be necessary to determine the effects of relatively low concentrations of organic substances that might be formed in the repository by both natural and man-made events under repositoryrelevant conditions for times sufficient to establish the thermodynamics and kinetics (rates) of such phenomena. The cost of such a task is estimated to be about $\$ 500,000$, and the duration of the task is estimated to be about 3 years. 
5. Because of the many reported incidents of pitting corrosion in lead alloys in water of moderately elevated temperature (corresponding to the conditions expected in the repository after the waste packages cool to below about $100^{\circ} \mathrm{C}$ ), it would be necessary to evaluate the behavior of candidate lead-based materials to pitting for times long enough to establish the occurrence and rate of growth of pits. This activity would cost about $\$ 200,000$ and take 1 year to complete.

6. Several incidents of galvanic corrosion of lead and lead-based alloys have been reported. This form of corrosive attack will occur when a lead-rich alloy is used in conjunction with container and canister materials in the waste package design, and the outer wall of the container is breached. In this task, lead alloys electrically coupled to either the exterior container wall material or to the inner canister material would be exposed to repository-relevant conditions of temperature and water chemistry for times long enough to quantitatively establish the occurrence and rates of reaction of the relevant galvanic corrosion phenomena. This task is estimated to take about 1 year and would cost about $\$ 200,000$.

7. The embrittlement of container materials by lead and lead alloys is a major concern. It is well known that lead severely embrittles nickel- and copper-based alloys. The nickel-base alloy 825 and $70 / 30$ copper/nickel are among the currently favored candidate alloys for containers. A thorough theoretical understanding would have to be developed to allow confident prediction of the very long-term behavior of container materials that have been exposed to molten or hot solid lead. Some critical issues to be addressed include (1) the influence of wetinu by liquid lead and lead-rict alloys on the type(s) and rate(s) of embrittlement of candidate nickel- and copperbased alloys; (2) the influence of tensile stresses in the closed waste-package containers; (3) the range of repository temperatures under which hot, solid lead and lead-base alloys interact with candidate nickel- and copper-base container materials, including the relative susceptibilities of various microstructures produced during the fabrication and closure of containers to subsequent embrittlement or stress-corrosion cracking. The estimated cost of such a program is about $\$ 2$ million, and the estimated time to completion is about 5 years.

8. A feasibility study has been conducted by Canadian researchers on the casting of lead into high level waste containers. The results were encouraging in somewhat smaller containers than those currently planned for Yucca Mountain. It would be useful to attempt the technique for the larger containers planned for the U.S. site to demonstrate that no large voids occur, that interstices are filled and, in particular, that the lead wets the oxidized fuel rods. Successful casting of molten lead (or lead-based alloys) into high-level waste containers containing consolidated spent fuel with very narrow interstices would need to be demonstrated in a hot-cell environment. Even if this process is within the reach of present-day technology, the problems of filling voids within the container at temperatures of $350^{\circ} \mathrm{C}$ and higher in a shielded work cell must be analyzed and suc- 
cessfuily demonstrated and a method of nondestructively inspecting the solidified mass to detect and measure void location and size must be developed. This study is estimated to take 3 years and cost $\$ 5$ million.

In summary, all of these studies would be expected to take 5 years, with all but the highly important embrittlement study complete after 3 years. The studies would be expected to cost a total of $\$ 9$ million. 
REFERENCES

Roy F. Weston, Draft MRS System Study, Task B, Facility Design (Repository MRS ), HQW 890106.0011.

DOE (U.S. Department of Energy), 1988a. Integrated Data Base for 1988:

Spent Fuel and Radioactive Waste Inventories, Projections, and Characteristics, DOE/RW-0006, Rev. 4, Washington, D.C. 
Table F-1. Distribution of spent-fuel assemblies for the consolidated case

\begin{tabular}{|c|c|c|c|c|c|}
\hline \multirow{2}{*}{\multicolumn{2}{|c|}{ Disposal containers }} & \multirow{2}{*}{$\begin{array}{r}\text { Configuration } \\
\text { designation } \\
\end{array}$} & \multirow{2}{*}{$\begin{array}{l}\text { Number of } \\
\text { packages }\end{array}$} & \multicolumn{2}{|c|}{ Number of assemblies } \\
\hline & & & & Per container & Total \\
\hline Consolidated & $\begin{array}{l}\text { PWR } \\
\text { BWR }\end{array}$ & $\begin{array}{l}1 \\
2\end{array}$ & $\begin{array}{r}18,451 \\
7,009\end{array}$ & $\begin{array}{r}6 \\
18\end{array}$ & $\begin{array}{l}110,706 \\
126,162\end{array}$ \\
\hline Intact & $\begin{array}{l}\text { PWR } \\
\text { BWR }\end{array}$ & $\begin{array}{l}4 \\
3\end{array}$ & $\begin{array}{r}1,192 \\
707 \\
\end{array}$ & $\begin{array}{l}3 \\
6\end{array}$ & $\begin{array}{l}3,576 \\
4,242 \\
\end{array}$ \\
\hline Total & $\begin{array}{l}\text { PWR } \\
\text { BWR }\end{array}$ & & $\begin{array}{r}19,643 \\
7,716\end{array}$ & & $\begin{array}{l}114,282 \\
130,404\end{array}$ \\
\hline
\end{tabular}

${ }^{a}$ Scenario 5 in the draft report for Task $B$ of the MRS systems studies, prepared for the DOE by Roy F. Weston, Inc., HQW 890106.0011. 


\section{CONTAINER}

Container outside diameter

Container wall thickness

Container inside radius

Container inside cross-sectional area

Fuel divider area

Hexagonal center area (configurations 1, 2, and 3 )

Triangular center area (configuration 4 )

ROD CROSS-SECTIONAL AREA
Configuration 1 ( $\operatorname{six} 15 \times 15$ arrays, 0.422 in. dia.)

Configuration 2 ( $187 \times 7$ arrays, 0.562 in. dia.)

Configuration 3 ( $\operatorname{six} 7 \times 7$ arrays, 0.562 in. dia.)

Configuration 4 (three $15 \times 15$ arrays, 0.422 in. dia.)
26 in.

$3 / 8$ in.

$125 / 8$ in.

500 in. $^{2}$

14.2 in. ${ }^{2}$

$103.5 \mathrm{in.}^{2}$

31.7 in. $^{2}$

\section{WASTE-PACKAGE VOLUMES}

Container interior volume $(500 \times 178)$

Fuel divider volume (14.2x178)

Hexagonal center volume (103.5x178)

Triangular center volume $(31.7 \times 178)$

\section{LEAD VOLUMES}

Configuration $1(500-14.2-188.7-103.5) \times(178)$

Conf iguration $2(500-14.2-218.7-103.5) \times(178)$

Configuration 3

Lead in center $(500-14.2-72.9) \times(178)$

No lead in center $(500-14.2-72.9-103.5) \times(178)$

\section{LEAD COST PER PACKAGE}

Configuration $1(19.9 \times 707.7 \times 0.42)$

Configuration $2(16.9 \times 707.7 \times 0.42)$

Configuration 3

Lead in center $(42.5 \times 707.7 \times 0.42)$

No lead in center $(31.9 \times 707.7 \times 0.42)$

Configuration 4

Lead in center $(40.3 \times 707.7 \times 0.42)$

No lead in center $(37.0 \times 707.7 \times 0.42)$
188.7 in. $^{2}$

218.7 in. $^{2}$

72.9 in. $^{2}$

94.4 in. $^{2}$

${ }^{a}{ }^{*}$ The values given here are based on the following assumptions: (1) the lead filler occupies 178 in. along the length of the container; (2) the length of the fuel rods is $178 \mathrm{in.}$ (actual lengths are $160 \mathrm{in.}$ for PWR fuel rods and $161 \mathrm{in.}$. For BWR fuel rods; (3) the density of lead is $707.71 \mathrm{~b} / \mathrm{ft}^{3}$; (4) the unit cost of lead is $\$ 0.42$ per pound (personal communication from $M$. J. Hadwin, Federal Industrial Services, Inc., November 1988); (5) in configurations 1 and 2 , the center regions are filled with hardware (i.e., there is no lead in these regions).

'Estimated from cross-section crawings (Figure F-I). 
Table F-3. Lead costs for Scenario 5 (consolidated assemblies)

\begin{tabular}{|c|c|c|c|c|c|c|c|c|}
\hline \multirow[b]{2}{*}{$\begin{array}{c}\text { Design } \\
\text { configuration }\end{array}$} & \multicolumn{4}{|c|}{ Cost of lead per package } & \multirow[b]{2}{*}{$\begin{array}{l}\text { Number of } \\
\text { packages }\end{array}$} & \multirow{2}{*}{\multicolumn{3}{|c|}{ Iotal cost of lead all packages }} \\
\hline & $\begin{array}{c}\text { Rod } \\
\text { compartment }\end{array}$ & comp & $\begin{array}{l}\text { enter } \\
\text { artment }\end{array}$ & Iotal & & & & $\begin{array}{l}\text { packages } \\
\text { in center }\end{array}$ \\
\hline $\begin{array}{l}\text { 1. Six Cnsd. } \\
\text { PWR Assembles. }\end{array}$ & $\$ 5,915$ & & - & $\$ 5.915$ & 18,451 & $\$ 109.1$ Million & & - \\
\hline $\begin{array}{l}\text { 2. Eighteen } \\
\text { consd. BWR } \\
\text { Assembles. }\end{array}$ & $\$ 5,023$ & & - & $\$ 5,023$ & 7,009 & $\$ 35.2$ Million & & - \\
\hline $\begin{array}{l}\text { 3. Six intact } \\
\text { BWR Assembles. }\end{array}$ & $\$ 9,482$ & & .149 & $\$ 12.631$ & 707 & $\$ 6.7$ Million & $\$ 8.9$ & Million \\
\hline $\begin{array}{l}\text { 4. Three intact } \\
\text { PWR Assembles. }\end{array}$ & $\$ 10.998$ & $\$$ & 980 & $\$ 11,978$ & 1,192 & $\$ 13.1$ Million & $\$ 14.3$ & Million \\
\hline TOTALS & & & & & 27,359 & $\$ 167.5$ Million & $\$ 164.1$ & Million \\
\hline
\end{tabular}


Table F 4 Lead costs for nonconsolidated case

\begin{tabular}{|c|c|c|c|c|c|c|}
\hline \multicolumn{7}{|c|}{ Cost of lead per package } \\
\hline $\begin{array}{l}\text { Design } \\
\text { Configuration }\end{array}$ & $\begin{array}{l}\text { Total No. } \\
\text { of Assmbis. }\end{array}$ & $\begin{array}{l}\text { No. of } \\
\text { Packages }\end{array}$ & $\begin{array}{l}\text { Rod } \\
\text { Compartment }\end{array}$ & $\begin{array}{l}\text { Center } \\
\text { Compartment }\end{array}$ & $\begin{array}{l}\text { No Lead } \\
\text { in Center }\end{array}$ & $\begin{array}{l}\text { Lead } \\
\text { in Center }\end{array}$ \\
\hline $\begin{array}{l}\text { 1. Six intact } \\
\text { BWR Assmbls. }\end{array}$ & 130,404 & 21,734 & $\$ 9,482$ & $\$ 3,149$ & $\$ 206.1$ Million & $\$ 274.5$ Million \\
\hline $\begin{array}{l}\text { 2. Three intact } \\
\text { PWR Assmbis. }\end{array}$ & 114,282 & 38,094 & $\$ 10,998$ & $\$ 980$ & $\$ 419.0$ Million & $\$ 456.3$ Million \\
\hline TOTALS & & 59,828 & & & $\$ 625.1 \mathrm{Mi} 71$ ion & $\$ 730.8$ Million \\
\hline
\end{tabular}


Table F-5. Distribution of assemblies for the hybrid case (Scenarios 2 and 4$)^{a}$

\begin{tabular}{|c|c|c|c|c|}
\hline \multirow[b]{2}{*}{ Disposal Containers } & \multirow{2}{*}{$\begin{array}{l}\text { Configuration } \\
\text { Designation }\end{array}$} & \multirow{2}{*}{$\begin{array}{l}\text { Number of } \\
\text { Packages }\end{array}$} & \multicolumn{2}{|c|}{ Number of Assemblies } \\
\hline & & & Per Container & Total \\
\hline Intact & 4 & 1,360 & 3 & 4,080 \\
\hline Intact & 3 & 710 & 6 & 4,260 \\
\hline Consolidated Hybrid & 5 & 29,485 & $\begin{array}{l}3 \text { (PWR) } \\
4 \text { (BWR) }\end{array}$ & $\begin{array}{r}88,455 \\
117,940\end{array}$ \\
\hline TOTALS & & & & \\
\hline $\begin{array}{l}\text { PWR } \\
\text { BWR }\end{array}$ & & & & $\begin{array}{r}92,535 \\
122,200\end{array}$ \\
\hline
\end{tabular}

${ }^{a}$ Scenarios 2 and 4 in the draft report for Task $B$ of the MRS systems studies, prepared for the DOE by Roy F. Weston, Inc., HQW 890106.0011. 
Table F-6. Adjusted distribution of assemblies for the hybrid case (Modified Scenarios 2 and 4$)^{\mathrm{a}}$

\begin{tabular}{|c|c|c|c|c|}
\hline \multirow[b]{2}{*}{ Disposal Containers } & \multirow{2}{*}{$\begin{array}{l}\text { Configuration } \\
\text { Designation }\end{array}$} & \multirow{2}{*}{$\begin{array}{l}\text { Number of } \\
\text { Packages }\end{array}$} & \multicolumn{2}{|c|}{ Number of Assemblies } \\
\hline & & & Per Container & TotaI \\
\hline Intact & 4 & 1,558 & 3 & 19,674 \\
\hline Intact & 3 & 710 & 6 & 4,260 \\
\hline Consolidated Hybrid & 5 & 31,536 & $\begin{array}{l}3 \text { (PWR) } \\
4 \text { (BWR) }\end{array}$ & $\begin{array}{r}94,608 \\
126,144\end{array}$ \\
\hline TOTALS & & & & \\
\hline PWR & & & & 114,282 \\
\hline BWR & & & & 130,404 \\
\hline
\end{tabular}

${ }^{a}$ Scenarios 2 and 4 in the draft report for Task $B$ of the MRS systems studies, prepared for the DOE by Roy F. Weston, Inc., HQW 890106.0011. 
Container outside diameter

Container vall thickness

Container inside radius

Total inside cross-sectional area

Fuel divider area

\section{CONTAINERS}

28 in.

$3 / 8$ in.

13.625 in.

583 in.

15 in. $^{2}$

SPENT FUEL

Rod cross-sectional area

PWR assemblies (three per package) ${ }^{D}$

BWR assemblies (four per package) $(4 / 6) \times(72.9)$

94.4 in. $^{2}$

VOLUMES

Total container volume

Fuel divider volume

Lead volume per package

$[101,104-(94.4) \times(178)-(48.6) \times(178)]$

$\cos \mathrm{T}$

48.6 in. $^{2}$

Cost of leaci per package

103,774 in. ${ }^{3}$

2670 in. $^{3}$

75,150 in. $^{3}$

$\left(43.8 \mathrm{ft}^{3}\right)$

${ }^{a}$ Assumptions and procedures of Table F-2 apply.

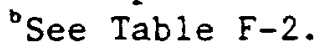


Table F-8. Lead costs for hybrid case (modified Scenarios 2 and 4 ) ${ }^{a}$

\begin{tabular}{|c|c|c|c|c|c|}
\hline \multirow[b]{2}{*}{$\begin{array}{l}\text { Design } \\
\text { Configuration }\end{array}$} & \multicolumn{3}{|c|}{ Cost of Lead Per Package } & \multicolumn{2}{|c|}{ - Cest of Lead-All Packages } \\
\hline & $\begin{array}{l}\text { Rod } \\
\text { Compartment }\end{array}$ & $\begin{array}{l}\text { Center } \\
\text { Compartment }\end{array}$ & $\begin{array}{l}\text { No. of } \\
\text { Packages }\end{array}$ & $\begin{array}{l}\text { No Lead } \\
\text { in Center }\end{array}$ & $\begin{array}{l}\text { Lead in } \\
\text { center }\end{array}$ \\
\hline $\begin{array}{l}\text { Three intact } \\
\text { PWR Assemblies }\end{array}$ & $\$ 10,998$ & $\$ 980$ & 5558 & $\$ 72.1$ Million & $\$ 78.5$ Million \\
\hline $\begin{array}{l}\text { Six intact } \\
\text { BWR Assemblies }\end{array}$ & $\$ 9,482$ & $\$ 3,149$ & 710 & $\$ 6.7$ Million & $\$ 8.9$ Million \\
\hline $\begin{array}{l}\text { Consolidated } \\
\text { Hybrid Assemblies }\end{array}$ & $s_{\$} \$ 13,013$ & - & 31,536 & $\$ 410.4$ Million & - \\
\hline TOTALS & & & & $\$ 489.2 \mathrm{Milli}$ ion & $\$ 497.8$ Million \\
\hline
\end{tabular}

a Scenarios 2 and 4 in the draft report for Task B of the MRS systems studies, prepared for the DOE by Roy F. Weston, Inc., HQW 890106.0011 . 


\section{REFERENCES}

Roy F. Weston, Draft MRS System Study, Task. B, Facility Design (Repository MRS), HQW 890106.0011.

DOE (U.S. Department of Eneıgy), 1988a. Integrated Data Base for 1988: Spent Fuel and Radioactive Waste Inventories, Projections, and Characteristics, DOE/RW-0006, Rev. 4, Washington, D.C. 
BLREAL OF MINES

2401 E STREET. NW.

WASHINGTON. D.C. 20241

June 5, 1989

Mr. Mark W. Frei, Director

Siting \& Facilities Technology Division

Office of Civilian Radioactive Waste Management

U.S. Department of Energy

Forrestal Building 7F-3217

1000 Independence Avenure, S.W.

Washington, DC 20585

Dear Mr. Frei:

Ref: A Research and Test Plan to Evaluate the Use of Lead in the Waste Packages for use in a Geological Repository at Yucca Mountain, Nevada.

As required by the original charge to the Peer Review Panel, appropriate research tasks have been identified to be performed under the DOE alternative waste package design program to evaluate the potential use of lead in any alternative waste package design. The Panel has identified the tasks that it believes are required if lead is to receive a iair and informed consideration in the selection of materials for any alternative waste package design. The Panel's recommendationsand projected costs have been written specifically for lead; however, additional or parallel tasks, with additional costs, would be needed to determine the suitability of other materials in any alternative waste package design.

As noted in the Panel's review comments of the draft report and DOE's responses to those comments, an alternative waste package design program is necessary if lead is to receive a fair evaluation as to its potential value in a waste package design for the Geological Repository at Yucca Mountain. The Peer Review Panel's recommendations for such a research and test plan are enclosed.

Sincerely,

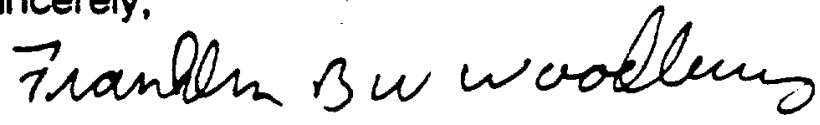

Franklin B. W. Woodbury, P.E.

Chairman, Peer Review Panel

Enclosure

cc: Members of the Peer Review Panel 


\section{TEST PLAN FOR EVALUATION OF LEAD AS A WASTE PACKAGE MATERIAL}

Lead has the following potential radionuclide containment roles in a high-level nuclear waste package design:

1. In the capacity of either a waste package container filler or a waste package container liner, lead could fulfill the requirements of a secondary containment barrier.

2. As a waste package container filler lead could assist in preserving the integrity of the spent fuel cladding by protecting it from stresses and impact loadings associated with transportation and handling. Because the cladding has a requirement in radionuclide control [as a barrier to release of fission gases and dissolution of the gap/grain boundary radionuclide inventory, and as a barrier to oxidation of the spent fuel matrix (DOE 1988)], this stabilizing role of a lead filler, possible poured in place, could assist in maintaining a radionuclide barrier that is essential in the current waste package reference design.

3. As a waste package container filler lead could enhance heat transfer from the spent fuel, and as either a filler or a liner it could provide radiation shielding to the vasste package environment.

4. As either a filler or a liner it could assist in criticality control by preventing entry and/or accumulation of water.

In performing the foregoing positive functions in a waste package design, lead must not compromise the integrity of other waste package structures, and it must not, in its own right, contribute significantly to contamination of the biosphere.

To perform the secondary containment barrier function (item 1 in the foregoing list), lead must demonstrate a high inherent corrosion resistance. This is a desirable trait in fulfilling all of the other functions noted in the list, but it is of critical importance, by definition, to the objectives of item 1.

Lead must not be capable of damaging the performance of the major structural members of a waste package by either a liquid-lead or solid-lead embrittlement mechanism. This is true regardless of the usage (items 1-4 on the preceding list). Damage of a waste package structure by lead ions in solution or lead corrosion products would only be considered harmful if it were the spent fuel cladding that was damaged, as any other barrier (in the reference design) would have failed by the time lead ions or lead corrosion products were formed. 
In order to fulfill the function described in item 2, the potentially important function of cladding preservation, as well as any of the functions requiring the filling of the waste package with lead, it is desirable that the feasibility of casting lead into a waste package containing radioactive spent fuel must be demonstrated. (There are other methods of putting fillers in place, but casting currently appears to be the most straightforwardand economical method.)

The foregoing considerations can be summarized in four major technical areas that require investigation and resolution before the use of lead in waste package designs can be defended:

1. The corrosion resistance of the lead or lead alloy

2. The potential effect of lead on other waste package structural materials

3. The transport properties of lead through the repository medium

4. The casting methodology.

The basic approach to conducting the required research, keyed in order to the items in the foregoing list, with estimates of the associated time and costs required, as presented below. It is assumed that all of the research work would be conducted under a quality assurance regimen consistent with impact level 1 of a DOE-approved NQA-1 quality assurance (QA) program, as the data obtained from any testing program would be expected to be directly used in waste package/waste repository technology and asesciated licensing activities.

\section{CORROSIONRESISTANCE}

Background. The corrosion of lead relevant to a waste package application may be separated into two major types: general corrosion and non-uniform corrosion. General corrosion is corrosion that takes place in a reasonably uniform fashion over the entire specimen surface. General corrosion can be enhanced by contact between dissimilar metals (galvanic corrosion), due to the electrical cell formed between the active (anodic) member of the couple and the less active (cathodic) member of the couple. Nonuniform corrosion comprises pitting corrosion, crevice corrosion, and intergranular corrosion. Pitting corrosion occurs when a susceptible area in a passive corrosion product film "breaks down," permitting an electrical current to flow between the (now anodic) site and the generally cathodic passive film. Crevice corrosion occurs because of a differing chemistry in the solution within a crevice, e.g., an oxygen concentration gradient, that forms an electrical cell that in turn causes rapid attack to occur in the (anodic) region in the depths of the crevice. Such a crevice might be found in a waste package, for example, at the boundary between a breached container and a lead filler. Intergranular attack takes place when the grain boundary region of an alloy does not have a corrosion resistance equivalent to the bulk of the material. 
The evaluation of the corrosion resistance of a waste package material, whether it the lead or some other barrier material, may be accomplished in two different ways: by service-simulatingtests (sometimes called "immersion tests") and electrochemical tests. In the former, metal samples are exposed to simulated repository environments for long time periods (to several years), with subsequent examination and evaluation and comparison to the state of the sample prior to the test. Electrochemical tests take advantage of the electrochemical nature of corrosion processes to draw conclusions concerning the corrosion rates of the materials as a function of alloy composition and environmental conditions, and the propensity for a given material in a given environment to exhibit a certain kind of corrosion attack, e.g., pitting or crevice attack. The electrochemical methods are relatively rapid and inexpensive, allowing the examination of many test variables, but the electrochemical results must ultimately be confirmed by long-term service-simulatingtests, as there is ultimately no substitute for the timedependent processes inherent in a long-term corrosion test.

Experiments performed to date at PNL (Guenther et. al. 1986; Pitman et. al. 1987; Westerman et. al. 1988) have shown generally good corrosion resistance of lead and lead alloys in simulated tuff repository environments. The lead specimens have exhibited adequately low corrusion rates and only uniform corrosion. However, the tests performed to date have not yet given a complete picture of the corrosion behavior of lead in a tuff repository; for the following reasons:

- The tests performed to date have been short-term compared to the minimum length of exposure generally considered to be necessary for repository-relevantcorrosion data (three to five years, with the longer time preferred).

- Radiation-corrosionresults are not yet available.

- The electrochemical evaluation of the lead alloys, and a determination of their propensity for pitting or crevice corrosion under repository-simulating conditions are not yet available.

- No tests have yet been conducted on lead under the appropriate formal $Q A$ requirements previously described. 
Test Plan. Both service-simulating tests and electrochemical tests would be conducted. Commercial-purity lead would be expected to receive the primary emphasis in the corrosion investigations. Lead alloys would be invoked only if initial tests indicated that commercial-purity lead showed deficiencies that could be circumvented by use of an alloy. Use of an alloy would require aging studies, to determine the potential importance of alloy element segregation. The test variables are listed below:

\begin{tabular}{|c|c|c|}
\hline 0 & Pre-test aging (alloy) & 200 to $300 \mathrm{C}, 1$ to 2 years \\
\hline ० & Corrosion test temperature & 50 to $250 \mathrm{C}$ \\
\hline 0 & Irradiation intensity & 0 to $1 \times 10 \exp 5 \mathrm{rad} / \mathrm{hr}$ \\
\hline 0 & Time & $\begin{array}{l}3 \text { to } 5 \text { years (service-simulating } \\
\text { tests) }\end{array}$ \\
\hline 0 & Environment & $\begin{array}{l}\text { - Vapor (air/steam mixtures) } \\
\text { - Liquid (simulated ground water, } \\
\text { unconcentratedand } \\
\text { concentrated) } \\
\text { - Long-term organic corrosion } \\
\text { resulting from } \\
\text {--combustion products } \\
\text {--human ingress }\end{array}$ \\
\hline 0 & Specimen geometry & $\begin{array}{l}\text { - Plain coupons } \\
\text { - Crevice specimens } \\
\text { - Galvanically coupled specimens }\end{array}$ \\
\hline
\end{tabular}

A statistical approach would be utilized to isolate those tests that would yield the maximum amount of information from the (extensive) test matrix implied by the foregoing table, and only those tests would be performed.

Time/Cost Estimates. It is estimated that the corrosion study would be completed and a final report issued within four to six years of its initiation (depending on the length of the long-term immersion tests conducted), and that the work could be performed for a total cost of $\$ 2.4 M(4-y r$ study) or $\$ 3 M(6-y r$ study).

\section{LEAD/STRUCTURALMATERIAL COMPATIBILITY}

Background. The use of lead as a filler material in waste packages could possibly give rise to embrittlement of a waste package structural material (for example, the container, if the structural material were in contact with the lead). Embrittlement of a number of 
alloys by both liquid and solid lead have been reported (Kamdar 1984), though it is important to recognize that low-temperature embrittlement is often associated with extremely high stress levels and the testing of hardened, high-strength materials. Work at PNL, using a slow-strain-rate (SSR) test method and liquid lead environment at $350 \mathrm{C}$ showed no embrittlement of either Alloy 825 or a low-carbon steel Westerman et. al. 1988). Nonetheless, the concern regarding this type of embrittlement is such that the elevated-temperature compatibility between lead and candidate structural metals (e.g., Alloy 825 and 70/30 copper-nickel alloy) must be demonstrated over test times of significant duration, and a satisfactory understanding of the embrittlement mechanism involved must be developed, before lead can be used in a waste package design in contact with structural materials.

No tests have yet been conducted on lead under the appropriate formal QA requirements previously described.

Test Plan. It is anticipated that the potential effect of the embrittlement of lead on candidate waste package structural materials will utilize a commercial-purity lead test environment maintained in a molten state. Solid lead will not be used as a test environment, as solid lead is known to promote embrittlement less strongly than liquid lead. The structural alloys will be those that have been selected by the Yucca Mountain Project (such a selection is scheduled for the end of FY 1989), exposed to the molten lead environment in both welded and non-welded conditions and in cold-worked and arin?ealed conditions. The basic test procedure will be the slew-strain rate (SSR) tesi procedure, in which the specimen is pulled in tension until it falls, in the test medium of interest as well as an in an inert medium for comparison. Test specimens would be both continually strained to iailure as well as simply dead-weight loaded. Embrittlement by the lead environment would be indicated by reduced ductility and/or a reduced tensile strength. No irradiated tests would be required. The test variables are listed below.

\begin{tabular}{|c|c|c|}
\hline 0 & Test temperature & $\circ 350 \mathrm{C}$ \\
\hline 0 & Time & $\begin{array}{l}\text { O } 2 \text { years maximum } \\
\text { (dead-weight-loadedtests) } \\
01 \text { to } 60 \text { days (SSR tests) }\end{array}$ \\
\hline o & Test environment & - Molten commercial purity lead \\
\hline 0 & Strain rate (imposed) & $\begin{array}{l}\text { o } 0 \mathrm{~cm} / \mathrm{cm}-\mathrm{sec} \text { (dead-weight tests) } \\
01 \times 10 \text { exp-7 to } 1 \times 10 \text { exp- } 4 \mathrm{~cm} / \mathrm{cm}-\mathrm{sec} \\
\text { (SSR tests) }\end{array}$ \\
\hline
\end{tabular}


A statistical approach would be utilized to isolate those tests that would yield the maximum amount of information from the test matrix implied from the foregoing table and test specimen material description, and only those tests would be performed.

Time/Cost Estimates. It is estimated that the tests could be completed and a final report produced with three years of study initiation, at a total cost of $\$ 0.9 \mathrm{M}$.

\section{TRANSPORT PROPERTIES OF LEAD}

The use of lead as a waste package material requires an analysis of the potential for its release from the waste package and subsequent migration to the biosphere. There are several chemical and physical processes that can sequester lead and limit its migration to the biosphere and in ground water. The two most important chemical processes are solubility and adsorption.

Lead metal is not thermodynamically stable in the expected tuff environment once the waste package container is breached. In the presence of moist air or ground water the metal will react to form more stable phases. Previous experimental work and thermodynamic calculations (Guenther et. al. 1985) suggest that mixed lead carbonate/hydroxides,for example plumbonacrite, form when lead metal is exposed to tuff ground water at $90 \mathrm{C}$ in the presence of air. Other theoretical calculations and experimental data on sligititi' alkaline waters under oxidizing conditions suggest that formation of hydrocerussite, chloropyromorphite, or hydroxypyromorphite can rapidly occur. These corrosion products limit lead solution concentrations to values between 0.01 and $0.8 \mathrm{mg} / \mathrm{L}$, dependent upon the exact conditions present (Bilinski and Schindler 1982; Taylor and Lopata 1984; Nriagu 1973 and 1974; and Lindsay 1979). Thus, under certain circumstances, the thermodynamic solubility constraint alone could control the concentration standard, while other circumstances would allow concentrations (based on solubility considerations) up to a factor of 10 higher than the drinking water standard. A review of the literature on lead interactions with sediments suggests that adsorption is quite effective in removing lead from solution (Adb-Elfattah and Wada 1981; Benjamin and Lecke 1980; Bittell and Miller 1964; Gadde and Laltenen 1973 and 1974; Guenther et. al. 1985; Leckle et. al. 1980; McKenzie 1980; Pickering 1983; Pitman et. al. 1987; Riffaldl et al. 1976; Scrudato and Estes 1975; Westermanet. al 1988). At pH values above 4 lead adsorbs strongly to a wide variety of minerals including most hydrous oxides (Al, Si, Fe, Mn); most clays (and, by inference, zeolites); and organic matter. Lead adsorption onto these substrates also exhibits a significant degree of irreversibility. That is, once adsorbed the lead is not easily removed and brought back into solution. The only process that diminishes lead's tendency for strong adsorption is formation of soluble Pb-organic complexes, a process not expected, under normal circumstances, in a repository constructed in tuff rock. 
This background material suggests that lead could be quite immobile in a repository environment. The following test plan is directed toward testing this hypothesis with tuffspecific experiments.

Test Plan. Lead compounds that are most likely to form upon contacting lead metal with moist air and tuff ground water will be used to develop solubility constraint data, to determine the range of expected lead concentrations within the tuff repository. Variables of importance are temperature, gas phase composition in unsaturated hydrologic conditions, and chemical composition of the water that eventually contacts the breached containers (especially $\mathrm{pH}$, total inorganic carbon, dissolved phosphate, and redox state). Batch-type solubility tests, with the likely lead corrosion product compounds in contact with the range of water compositions expected in the repository, will be performed. The corrosion products created on the lead specimens in the Corrosion Resistance task will be identified to ensure that they are the same compounds as the compounds used in this first suite of tests. (If they are not exactly the same, they must have a similar solubility.) The composition of the waters will be determined as a function of time until steady-state conditions are reached. The experimental results (solution analyses and ending excess solids identification) will be compared with geochemical code calculations to establish whether the thermodynamic approach of the codes is accurate.

A second suite of experiments will determine empirically how well tuff rock, its constituent minerals, and other sediments along the liow path to the biosphere adsorb lead from solution. Lead in the dissolved form determined to be present in the leachates from the solubility tests will be placed in synthetic waters approximating those leaving the repository region. These solutions will be used in the adsorption tests.

Batch adsorption tests will be used to screen the rock sediments and minerals. For those materials that show mediocre to poor adsorption properties, flow-through column tests will be used to assure that conservative estimates of lead migration are measured. (Batch tests sometimes overestimate adsorption tendencies and thus some validation tests, using a flow-through approach, are advised.) Selected adsorption isotherm tests, involving the measurement of lead adsorption versus lead starting concentration, will be performed to investigate the adsorption capacity of tuff rock.

Time and Cost Estimate. It is estirnated that the solubility and adsorption studies would be completed and a final report issued within three years of the task initiation, for a total cost of $\$ 1.5 \mathrm{M}$. 
Background. The way in which lead is applied to a waste package will be dependent upon the primary function of the lead. Application is likely along the lines shown below:

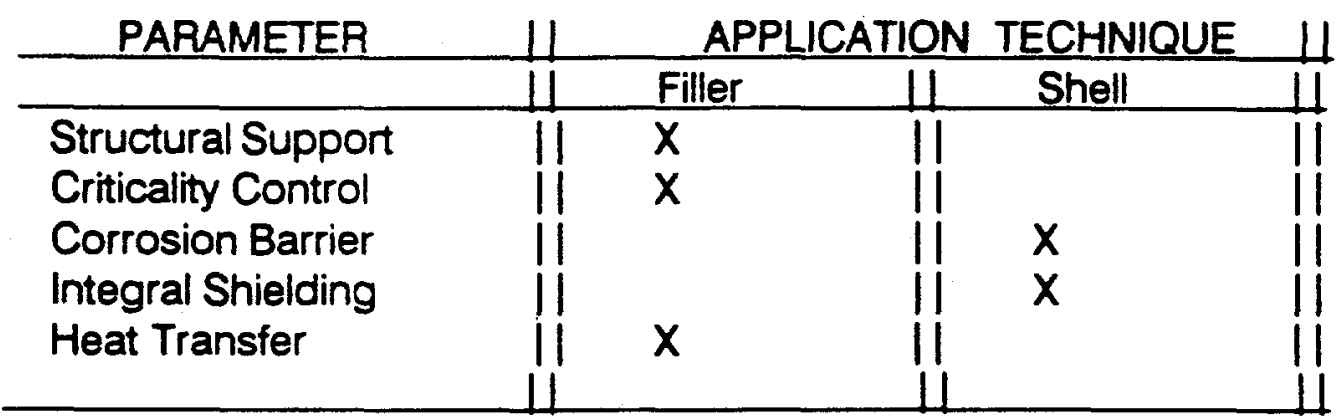

This division is supported by information in the draft report and by normal engineering practice. As examples: where structural support is the required parameter, a lead shell contributes virtually no load-bearing capability; for integral shieiding, cast fillers provide little additional attenuation compared to a shell but add three times the weight. If a lead corrosion barrier is required or desired independent of other application parameters, shell fabrication techniques are relatively more straightforward, use existing fabrication and inspection technology, and do not have to address remotely-controlled fabrication activities within shielded facilities.

The use of lead as filler (as opposed to a "shell") will require development and demonstration of techniques which produce castings of the quality needed for the application. Similarly, inspection techniques to assure casting/containerquality will need to be developed. It should also be recognized that supporting research may be necessary in such areas as development of lead alloys for optimum casting characteristics and corrosion resistance.

Much of the initial development can be performed on a reduced scale with nonradioactive surrogate fuel using earlier Canadian work as a basis. Ultimately, it will be necessary to develop and demonstrate the capability to remotely cast and inspect full scale spent fuel packages in a shielded facility. Shielded facilities of sufficient size to perform this type of work are available, but limited in number.

Test Plan. The development of techniques to cast filler in full-sized spent fuel packages should first be developed using surrogate fuel ("cold" fuel or fuel simulators). Following successful development of the basic techniques, the processes can be adapted to meet the restrictions of remotely operated facilities, and the final development/demonstration runs performed using actual spent fuel. The major tasks, with approximately durations and costs for "hot" and "cold" tests, are outlined below. 
1. Develop capability to cast lead into repository containers, using surrogate spent fuel.

The work at Atomic Energy Canada and in Sweden has cast lead into prototypes of their anticipated waste package with cold fuel. This test demonstrated lead's ability when used as a cast filler in a suitable (if scaled-down) configuration and to fill-in the small gaps between rods. The Canadian approach will be applied using a fullsized US geometry and cold or surrogate fuel. The task will demonstrate the process application at full scale with special attention to future remote-operations requirements, and will answer many of the needs expressed in the draft report. Included in this task will be investigations of solidification techniques to prevent voids in pure lead, and macro-segregation in dilute alloys such as $\mathrm{Pb}-1.5 \% \mathrm{Sb}$ and $\mathrm{Pb}-1.5 \% \mathrm{Sn}$.

2. Develop and apply capabilities to non-destructively examine the casting for voids and gaps, and to determine the extent of segregation of alloying elements, if present. Non-destructively test the casting generated by (1) above to identify the presence of voids. The acceptance criteria and, if appropriate, a repair technique should be developed to fill observable shrinkage gaps around fuel rods and inside the container if it is judged that such gaps are inimical to container performance. Existing analytical techniques will be used to monitor segregation and gaps formation. However, other inspection techniques such as high frequency ultrasound and neutron attenuation will be considered.

Tasks 1 and 2 will require approximately $18-20$ months and $\$ 4 \mathrm{M}$.

3. Adapt techniques derived from Canadian and Swedish experiments and task (1) to full-scale operations in existing remote-handling facilities. Secure necessary environmental permits for lead-melting operations in shielded facilities.

4. Perform small-scale lead casting experiments using irradiated spent fuel to determine the parameters for rod-wetting and "crud" removal and floatation.

5. Repeat task (1) above using irradiated spent fuel. Using techniques and procedures from task (2), examine the resulting casting for defects. Monitor the extent of segregation of alloying elements, if applicable. Determine the extent of "crud" deposition on outer surfaces of casting.

Tasks 3, 4 and 5 will require approximately 24-28 months and \$12M. 
6. Clean up laboratories and remote-handling facilities; return "unused" spent fuel to storage; disposition lead-encased spent fuel, toxic- and mixed-waste generated by the project.

Task 6 will require approximately 10 months and \$2M.

Time and Cost Estimate. It is estimated that the development testing and reporting activities for applications requiring lead as a filler would be completed in 3.5 to 4 years at a cost of $\$ 16 \mathrm{M}$. An additional 10 months and $\$ 2 \mathrm{M}$ will be required for cleanup of remote-handlingfacilities and disposition of the toxic-and mixed-wastes generated by the project.

\section{COST SUMMARY}

TASKS

Corrosion Resistance

Structural Material Compatibility

Transport Properties

Fillers and Castings
TIME

4 to 6 years

3 years

3 years

4.3 to 4.6 years

3 to 6 years
COSTS

$\$ 2.4$ to 3 Million

$\$ 0.9$ Million

$\$ 1.5$ Million

$\$ 18$ Million

Totals

$\$ 22.8$ to 23.4 Million 


\section{REFERENCES}

Adb-Elfattah, A. and K. Wada. 1981. "Adsorption of Lead, Copper, Zinc, Cobalt, and Cadmium by Soils that Differ in Cation-Exchange Materials." J. Soil Sci. 32:271-283.

Benjamin, M. M. and J. O. Leckle. 1980. "Adsorption of Metals at Oxide Interfaces; Effects on the Concentration of Adsorbate and Competing Metals." Contaminants and Sediments, vol 2, ed., R. A. Baker, pp. 305-332. Ann Arbor Science, Ann Arbor, Michigan.

Bilinski, H. and P. Schindler. 1982. "Solubility and Equilibrium Constants of Lead in Carbonate Solutions." Geochim, et Cosochim, Acta, 46:921-928.

Bitteil, J. E. and R. J. Miller. 1964. "Lead, Cadmium, and Calcium Selectivity Coefficients on a Montmorillonite, Illite, and Kaolinite." J.Environ. Qual. 3:250-253

DOE. 1988 Site Characterization Plan, Yucca Mountain Site, Nevada Research and Development area. Nevada. DOE/RW-0199. Volume VII, Part B, Chapter 8 , P. 8.3.5.9-8; pp 8.3.5.9-23 to 8.3.5.9-32; pp. 8.3.5.10-38 to 8.3.5.10-43.

Gadde, R. R. and H. A. Laitinen. 1973. "Study of the Sorption of Lead by Hydrous Iron Oxide." Environ. Letters. 5:223-225.

Gadde, R. R. and H. A. Laitimen. 1974. "Studies of Heavy Metal Adsorption by Hydrous Iron and Manganese Oxides." Anal. Chem. 46:2022-2026.

Guenther, R.J., S. G. Pitman, and R. E. Westerman. 1985 Potential Uses of Lead in Nuclear Waste Disposal. LM-337-4. Prepared for the International Lead-Zinc Research Organization, Inc., by Battelle, Pacific Northwest Laboratories, Richland, Washington, 99352.

Guenther, R.J., S. G. Pitman, and R. E. Westerman. 1986 Potential Uses of Lead in Nuclear Waste Disposal. LM-337-5. Prepared for the International Lead-Zinc Research Organization, Inc., by Battelle, Pacific Northwest Laboratories, Richland, Washington, 99352.

Kamdar, M.H., Editor. 1984. "Embrittlementby Liquid and Solid Metals." Conference Proceedings, Metallurgical Society of AlME, Warrendale, Pennsytvania.

Leckle, J.O., M.M. Benjamin, K. Hayes, G. Kautman, and S. Altman. 1980. Adsorption/ Coprecipitation of Trace Elements from Water with Iron Oxyhydroxide. EPRI CS-1513, Electric Power Research Institute, Palo Alto, California. 
Lindsay, W.L. 1979. Chemical Equilibria in Soils. John Wiley and Sons, New York, N.Y.

Mathew, P. M., 1986. "Casting Properties of Metal Matrices for Nuclear Fuel Waste

Disposal: Review and assessment,"Atomic Energy Canada Report TR-371.

McKenzie, R.M. 1980. "The Adsorption of Lead and Other Heavy Metals on Oxides of Manganese and Iron." Aust. J. Soil Res. 18: 61-73.

Nriagu, J.O. 1973. "Lead Orthophosphates.II. Stability of Chloropyromorphiteat 25 C." Geochim et. cosochim. Acta. 37: 367-377

Nriagu, J.O. 1974 "Lead Orthophosphates.IV. Formation and Stability in the Environment." Geochim et. cosochim. Acta. 38: 887-898.

Pickering, W. E. 1983. "Extraction of Copper, Lead, Zinc, or Cadmium lons Sorbed on Calcium Carbonate." Water, Air, and Soil Pollut. 20: 299-309.

Pitman, S. G., R. L. Erikson, R. J. Serne, Guenther, R.J., and R. E. Westerman. 1987 Potential Uses of Lead in Nuclear Waste Disposal. LM-337-6. Prepared for the International Lead-Zinc Research Organization, Inc., by Battelle, Pacific Northwest Laboratories, Richland, Washington, 99352.

Riffaldi, R. P. Levi-Minzi, and G.F. Soldatini. 1976. "Pb Adscrption ty Soils II. Specific Pb Sorption." Water, Air, and Soll Pollut. 6:119-128.

Scrudato, R.J. and Estes, E.L. 1975. "Clay-Lead Sorption Relations." Environ. Geology. 1:167-170.

Taylor, P. and V.J. Lopata. 1984. "Stability and Solubility Relationships Between Some Solids in the System PbO- $\mathrm{CO}_{2}-\mathrm{H}_{2} \mathrm{O}$." Can. J. Chem. 62:395-402.

Westerman, R. E., S. G. Pitman, and M. R. Telander. 1988. Potential Uses of Lead in Nuclear Waste Disposal. LM-337-7. Prepared for the International Lead-Zinc Research Organization, Inc., by Battelle, Pacific Northwest Laboratories, Richland, Washington, 99352. 